\title{
HYMENOPTERA FROM TURKEY SYMPHYTA
}

BY

R. B. BENSON

British Museum (Natural History)

Pp. I09-207; 42 Text-figs.

BULLETIN OF

THE BRITISH MUSEUM (NATURAL HISTORY) ENTOMOLOGY Vol. 22 No. 4

LONDON : 1968 
THE BULLETIN OF THE BRITISH MUSEUM (NATURAL HISTORY), instituted in I949, is issued in five series corresponding to the Departments of the Museum, and an Historical series.

Parts will appear at irregular intervals as they become ready. Volumes will contain about three or four hundred pages, and will not necessarily be completed within one calendar year.

In I965 a separate supplementary series of longer papers was instituted, numbered serially for each Department.

This paper is Vol. 22, No. 4 of the Entomological series. The abbreviated titles of periodicals cited follow those of the World List of Scientific Periodicals.

World List abbreviation:

Bull. Br. Mus. nat. Hist. (Ent.).

(C) Trustees of the British Museum (Natural History) 1968 


\title{
HYMENOPTERA FROM TURKEY SYMPHYTA
}

\author{
By R. B. BENSON*
}

SYNOPSIS

The Sawflies of Asiatic Turkey and neighbouring countries (from Israel and Cyprus to Transcaucasia and Iran) are listed; over 370 from Asiatic Turkey itself, 50 of these for the first time. Twenty-three new species or subspecies are described and lectotypes designated for seven species. Keys to world species are given for genera or generic-groups centred in this region. The account is based mainly on the collections made in Turkey by Messrs. K. M. Guichard and D. H. Harvey in 1959 , I960 and 1962.

CONTENTS

\begin{tabular}{|c|c|c|c|c|c|c|c|c|c|c|c|}
\hline INTRODUCTION & . & . & . & . & . & . & . & . & . & . & . \\
\hline Xyelidae & . & . & . & . & . & . & . & . & . & . & . \\
\hline PAMPHILIIDAE & & . & . & . & . & . & . & . & . & & . \\
\hline MEgalodontin & $\mathrm{DAE}$ & . & . & . & . & . & . & . & . & & . \\
\hline XIPHYDRIIDAE & & . & . & . & . & . & . & . & . & & . \\
\hline SiricidaE & . & . & . & . & - & . & . & . & . & & . \\
\hline ORUSSIDAE & . & . & . & . & . & . & . & . & . & & . \\
\hline Cephidae & . & . & . & . & . & . & . & . & . & & . \\
\hline ARGIDAE . & . & . & . & . & . & . & . & . & . & & . \\
\hline Cimbicidae & . & . & . & . & . & . & . & . & . & . & . \\
\hline Tenthredinid & $\mathrm{AE}$ & . & . & . & . & . & . & . & . & & . \\
\hline Selandriin & & . & . & . & . & . & . & . & . & & . \\
\hline Blennocan & apinae & & . & . & . & . & . & - & . & & . \\
\hline Tenthredil & ninae & . & . & . & . & . & . & . & . & & . \\
\hline Nematina & & . & . & . & . & . & . & . & . & & . \\
\hline References & . & . & . & . & . & . & . & . & . & & . \\
\hline INDEX . & . & . & . & . & . & . & . & . & . & & . \\
\hline
\end{tabular}

I N T RODUCTION

A GENERAL account of the fruitful entomological expeditions of Kenneth M. Guichard and David H. Harvey to Turkey in I959, I960 and I962 has already been published (Guichard \& Harvey, I967). In the pages that follow, the numbers given (in parentheses) after the names of the Provinces refer to the Guichard \& Harvey (I967) collecting site-numbers. For dates and ecological details of the sites, reference must be made to that paper. The present work on the sawflies, though based mainly on the Guichard and Harvey collections, has been broadened to include material from other countries bordering the eastern Mediterranean, such as that collected by G. A. Mavromoustakis in Cyprus (Benson, I954), by Dr. Bytinski-Salz and others in Israel (Benson, I955), by Dr. Zhelochovtsev (I94I) and Dr. Dadurian (I958) in Armenia, by G. Heinrich in the Elburz Mountains, N. Iran (Berlin

* Since the submission of this paper for publication, we learned with deep regret of the death of the author. Certain editorial changes have been made in the paper, which we were unable to submit to him. (Editor's Note.) 
Museum) and more recently by D. B. Baker on the S. Caspian Coast and Elburz Mountains of N. Iran.

There is no doubt that in collecting this material, the larger and more highlycoloured flower-haunting species have been favoured, whereas most of the small dark inconspicuous species on low plants, as well as those associated with forest trees, have yet to be explored. The most useful approach therefore seemed to be to treat this fauna as though it were an extension of that of $\mathrm{C}$. Europe as described by Enslin (I9I2-I8) and Benson (I95I-58), and in the families other than the Tenthredinidae, the Palaearctic fauna described by Gussakovskir (I935 and I947). References to species given in full by Konow, I905 or Gussakovskir are not repeated here.

Wherever possible, new keys have been provided to the known world species for the genera centred in the E. Mediterranean: i.e., for Corynis, Tenthredopsis, Cuneala, Elinora and Sciapteryx.

In Tenthredo a key has been constructed to world species-groups, and separate keys to species have been provided for the following species-groups: bifasciata, zonula, and maculata-temula; keys are also provided as follows: Calamenta and Trachelus species of the E. Mediterranean; the picipes-ciliatus-group of Dolerus; Periclista and the blanda-duodecimpunctata- and the postica-groups of Macrophya in the W. Palaearctic.

I am much indebted to many people who have helped me in this work: especially to K. M. Guichard and D. H. Harvey for their careful attention to collecting sawflies in Turkey, and to D. B. Baker for the great care he has taken in collecting sawflies for me in N. Iran; to Dr. Oehlke of the Deutsches Entomologisches Institut, Eberswald, Germany for his continued kindness in lending me numerous Konow types for study; to Dr. Königsmann of the Zoologisches Museum der Humboldt-Universität zu Berlin for lending me Dr. Heinrich's material from the Elburz Mountains etc.; to Dr. Zhelochovtsev of Moscow for sending in exchange most valuable representatives of species collected by himself in Armenia; to Dr. F. Wolf of the Facultés des Sciences Agronomiques, Gembloux, Belgium, for lending me material collected in Turkey in 1965 by Dr. Demelt.

Unless otherwise indicated, the new Turkish records given below are of specimens collected by Guichard or Harvey in I959, I960 or I962. Those marked with an asterisk $(*)$ are new to the recorded fauna of Turkey and a dagger $(\dagger)$ indicates that the type has been examined in the course of this work.

\section{XYELIDAE}

Xyela graeca J. P. E. F. Stein

Xyela graeca J. P. E. F. Stein; Benson, 1958.

Turkey, C. and W.: Ankara (I3), 5 \%; Izmir (Smyrna).

Algiers, Austria, Greece, Roumania, Turkey and Israel.

\section{PAMPHILIDAE}

For a key to the palaearctic species see Gussakovskiir I935. 
*Acantholyda hieroglyphica (Christ)

Turkey, C.: Ankara (3) I ㅇ; Ankara, Cankaya, I , I3.vi.rg63 (H. Özeren). EUROPE and TURKEY.

Acantholyda fumata (Enslin)

Turkey, S.: Mersin, Toros Dagi [“ Cilicischer Taurus ”], (type locality). Endemic.

Cephalcia hartigi (Bremi)

C. European Alps and Transcaucasia.

* Neurotoma fausta (Klug)

Turkey, W.: Bursa, Karacabey, iv-v.I928 (Ajtai).

C. and S. Europe and Turkey.

\section{Neurotoma saltuum (L.)}

Turkey, N.: Sakarya, Adapazari, on Prunus armeniaca L., 2.vi.I957 ( $M$. Akdogan).

Europe, Asia Minor, Turkey and Transcaucasia.

*Neurotoma nemoralis (L.)

Turkey, C. : Kütakya, Sureya, I923, on leaves of Prunus cerasus L.

Europe and Turkey.

Celidoptera maculipennis (J. P. E. F. Stein)

Turkey, C.: Ankara, Küre Daĝ, near Bala, I500 m., 2 ô, 2 ㅇ, Io.v.r959, flying round Prunus spinosa L. (E. S. Brown).

Previously recorded only from Turkey, W. and C.: Izmir and Amasya Provinces. Endemic.

Pamphilius caucasicus Gussakovskiǐ, I935

Transcaucasia. Endemic.

Pamphilius trigarius Konow

Transcaucasia. Endemic.

Pamphilius lethierryi (Konow)

Transcaucasia. Endemic.

Pamphilius aurantiacus (Giraud)

S. Europe and Transcaucasia. 


\section{MEGALODONTIDAE}

The species of this family are found mainly as adults on the flower tables of Umbelliferae, on which plants the larvae feed socially in webs. The species are keyed by Gussakovskiǐ, I935.

\section{Megalodontes imperialis Konow}

ISRAEL and TURKEY.

\section{Megalodontes phoenicius (Lepeletier)}

Israel, Syria and Turkey.

\section{Megalodontes kohli Konow}

Turkey, C. N. and N.E.: Amasya (5); Kayseri (4); Samsun (3); Erzurum (4). 4 ㅇ.

Crimea and Turkey.

\section{*Megalodontes multicinctus (Mocsáry)}

Turkey, C.: Ankara, Bala district, Ucern, 3 ㅇ, 28.v.I959 (E. S. Brown).

TURKey and Transcaucasia.

\section{Megalodontes exornatus (Zaddach)}

Hungary, Greece, Turkey and Transcaucasia.

\section{Megalodontes loewi (Stein)}

TURKEY and Transcaucasia.

\section{Megalodontes flabellicornis (Germar)}

Turkey, C. and N.E.: Nigde (5); Erzurum (I and 4); Artvin (7). 2 o, 8 q.

S. Europe and Turkey.

\section{Megalodontes escalerai Konow}

Lebanon: Djezzine, I + , 2.vi.r953 (G. A. Mavromoustakis).

Lebanon, Israel and Syria.

\section{Megalodontes pectinicornis (Klug)}

Turkey, C. and S.: Ankara (I2); Amasya (5, 7 and I4); Mersin (9). 20 ô, 35 ㅇ. HUNGARY and TURKEY. 
Mesopotamia.

\section{Megalodontes olivieri (Brullé)}

\section{Megalodontes medius Konow}

Turkey, N.W. and C.: Bursa (4); Corum (2). 2 ô, 2 q.

S.E. Europe, Turkey and Transcaucasia.

\section{*Megalodontes laticeps Konow}

Turkey, C.: Konya, Aksehir, I + , I-I2.vi.I955 (Seidenstücker); Nigde (I). I 9 ; Kayseri (4), I $q$. Israel: Carmel, Place of Sacrifice, 2 ô, I + , 26.iii-9.iv. I930 (Tapuchi).

S.E. Europe, Turkey and Israel. Not previously recorded outside Europe.

\section{Megalodontes flavicornis (Klug)}

Turkey, N.E.: Artvin (7). I + ; Iran: Azerbaijan, Bazergan, I300 m., I + , 25.v.I960 (E. S. Brown).

S.E. Europe, Turkey, Transcaucasia, N. Iran and W. Turkmen.

\section{Megalodontes aquilus Konow}

Transcaucasia.

\section{*Megalodontes klugi (Leach)}

Tarpa spissicornis Klug.

Turkey, N.W.: Bursa (9). I ô.

C. and S. Europe and Turkey.

\section{Tristactus judaicus (Lepeletier)}

Tarpa judaica Lepeletier.

$T$. caesariensis Lepeletier.

$\dagger$ Tristactus punctatus Konow, syn. $\mathbf{n}$.

A series of this species (I4 $\hat{0}$, II 9 ) from S. TuRkEY : Mersin (5) agrees with a series given to the B.M. (N.H.) by Enslin from S. Turkey: Mersin, Tarsus, 23-24.iv. I955 (Seidenstücker) and S.E. Turkey: Diyarbakir, Ergani (Osmaniye), 5-6.v.I955 (Seidenstücker). These all have strongly infuscate wings, the males with a white clypeus and mandibles, and the females with dark mandibles and a variable extension of black on the clypeus; it would not be surprising to find individuals with an entirely black clypeus and caesariensis would seem to be just such an aberration. A series from Israel: Mt. Tiberias, 2 ô, 20.iii.I939 (Palmoni), I ô, I4.iv. Ig63 (C. H. Andrewes); Benkamina, I ㅇ, 23-25.iii.I942 and Elon, I ㅇ, I8.v.I946 (H. Bytinski- 
Salz) differ from the form from Turkey in having subhyaline wings. The punctation of the mesonotum is also variable and $T$. punctatus is not clearly differentiated.

TURKey, Syria, IsRael.

\section{XIPHYDRIIDAE}

For a key to palaearctic species see Gussakovskiǐ, I935.

Xiphydria caucasica Semenov \& Gussakovskiľ

TRANSCAUCASIA.

\section{SIRICIDAE}

For keys to species see Benson, I943.

\section{SIRICINAE}

Xeris spectrum (L.)

Turkey, N.E.: Trabzon (I4). 3 ㅇ.

Europe to Caucasus and Asia Minor, Siberia and mountains to Heptapotamia, Sakhalin, boreal N. America and mountains south to Colorado.

\section{Urocerus augur augur (Klug)}

Sirex cedrorum Smith.

Urocerus augur bensoni Maa, I949, syn. $\mathbf{n}$.

Turkey, N.E.: Artvin (5). 2 in a timber yard.

Mountains of C. Europe, Turkey and Lebanon.

Urocerus augur sah Mocsáry

Turkey, W.: Izmir, Odemis, Boz Sira Daglari, I300-I900 m., I ㅇ, I6. viii. I950 (P. H. Davis).

Mountains of N. Africa, W. Turkey, Transcaucasia, N. Iran, Turkestan and AfGHanistan.

\section{Urocerus gigas gigas (L.)}

Occasionally introduced from Europe.

Urocerus gigas argonautarum Semenov

Turkey, N. and N.E.: Bolu (3). I $q$; Trabzon (2). I $q$ in timber yard. Turkey and Transcaucasia, 
Sirex juvencus (L).

Transcaucasia (Dadurian, I958). Holarctic.

\section{Sirex cyaneus dux Semenov}

This form agrees with S. cyaneus F. in ovipositor/sawsheath ratio and in all other essential characters, but the total ovipositor is longer than in that form and is almost as long as a fore wing (see Benson, I943). It seems reasonable to treat forms differing only in ovipositor/fore wing ratio in Sirex as at most subspecies, as was done by Benson in Urocerus. Transcaucasia.

\section{Sirex noctilio F.}

Turkey, S.W.: Denizli, ex Pinus brutia Ten, 3 ô, 2 ㅇ, x. I962 (Dr. Hasan Canak$\operatorname{siog}(u)$.

This series of small dark-winged specimens ( $\mathrm{I} 5-\mathrm{I} 6 \mathrm{~mm}$. long) and a similar series from Cyprus, X.I927 (H. M. Morris) in the B.M. (N.H.) may have been imported.

Temperate Eurasia, introduced into N. America, New Zealand and Australia.

\section{TREMEGINAE}

Tremex jakovlevi Semenov

TRANSCAUCASIA.

\section{ORUSSIDAE \\ Orussus abietinus (Scopoli)}

Europe, Syria and Caucasus.

*Mocsarya syriaca Benson, I936

The unique original specimen of this species was collected at Akbés (Meidan Ekbes) on the Turkish border of Syria and as it had lost its antennae, its original generic assignment was doubtful. Guichard and Harvey collected a second specimen, I ot in N. TuRkeY: Zonguldak, near Ulus, $c$. IOo m., I7.vii. I962. The possession of antennae with a small scape shows that the species had been correctly assigned to Mocsarya rather than to Chalinus. The male is only $9 \mathrm{~mm}$., with subhyaline wings, and the carinae within the facial field are incompletely developed, not unnaturally in a small specimen.

Syria and TURKEY.

\section{GEPHIDAE}

A classification of the Cephidae was given by Benson (I946) and most of the species from Asia Minor can be named in Gussakovskily's work (I935), but keys to E. Mediterranean Calameuta and Trachelus are given below. 


\section{HARTIGIINI}

\section{Hartigia nigra (Harris)}

Turkey, N.E.: Erzurum (5). I +

C. and S. Europe and Turkey.

Hartigia linearis (Schrank)

C. and S. Europe, Transcaucasia, S. Siberia.

\section{[Janus femoratus (Curtis)}

Turkey, N.W.: Istanbul (3). I 9 . Not recorded yet from Asia Minor.

This specimen differs from the normal C. European form in having a brown instead of yellowish white tegula.

EUROPE.]

\section{[Janus compressus (Fabricius)}

Turkey, N.W.: Istanbul (3). 2 ㅇ. Likewise not yet recorded from Asia Minor.

S. Europe to N. Caucasus.]

\section{Syrista parreyssii (Spinola)}

Turkey, N.W., C. and N.E.: Tekirdeg (I); Amasya (3, 4, 5 and 7); Ankara (33); Nigde (5); Erzurum (4). I5 ô, I2 9 .

The flight period is from the end of May in Amasya and Nigde, to 23rd July at 2,300 m., Erzurum.

S. Europe to Caucasus, Turkey, Cyprus and Israel.

\section{PACHYGEPHINI}

\section{Pachycephus smyrnensis J. P. E. F. Stein}

Pachycephus brevis Ghigi, syn. n.

$\dagger$ Spatulocephus sanctus Pic, syn. $\mathbf{n}$.

This species is common and very variable in size (6-II mm.) and colour pattern.

In Cyprus and Israel it flies in March and April. In Turkey at Mersin (8), at $600 \mathrm{~m}$. and at Amasya (I, 2 and 3) at 400-500 m., it was found in the last week of May and first week of June. $39 \widehat{0}, 50$ 우.

Balkans, Turkey, Cyprus, Syria, Israel and Transcaucasia.

\section{Pachycephus aeneovarius $\mathrm{Kohl}$}

This species is very similar to $P$. smyrnensis except that the dark colour of the body has greenish and bluish metallic reflections, and the head and thorax are even more densely punctured.

Only known from Turkey: Eskischir, Sebandseln (Kohl, 1905). Endemic. 


\section{Pachycephus persicus Gussakovskiı̌}

This species is based on a unique of $6 \mathrm{~mm}$. length, in which the yellowish white markings are replaced by white. It would seem probable that this is a form of P. smyrnensis.

S. IRAN: Luristan, iii.I904.

\section{[Pachycephus cruentatus cruentatus (Eversmann)}

This species is distinguished from the above in: (I) lacking any sign of a genal carina on the lower lateral hind margin of the head capsule; (2) the strongly shining surface of head and thorax with obsolescent punctures; and (3) the deeply infuscate wings.

S. Russia, Crimea, N. Caucasus].

\section{Pachycephus cruentatus konowi Kohl}

This subspecies differs from the typical form in having more extensive red colour on the legs. It was described originally from Turkey: Kayseri, Ereiyas and Dagi, and has also been found in ISRaEL, at Urim.

\section{Characopygus decoratus sp. $\mathrm{n}$.}

․ Black with following parts yellow: palps, mandibles (except teeth), fleck in middle of fronto-clypeal area, pronotum, behind, tegula, small fleck on each lateral mesonotal lobe, large fleck on scutellum, upper angle of mesepisternum legs (except most of coxae, trochanters and bases of femora which are black, and the yellow colour is reddish tinged) tergites 6,7 and 9 almost entirely, 3rd laterally and with medial fleck, and 8th with lateral and medial flecks broad, apical margin of hypopygium, small fleck on the preceding sternite, and lower edge of basal plate flanking the ovipositor. Wings hyaline; stigma, $C$ and $S c$ yellow; rest of venation brown to piceous.

Length: I I mm. (without ovipositor).

Head normal, subparallel-sided. Distance between antennal sockets compared to distance between socket and middle of anterior tentorial pit as $\mathrm{I} \cdot 0$ : $0 \cdot 8$. Antenna 22-segmented; becoming clavate from about 7 th segment; roth onwards transverse, and 20 th about two and a half times broader than long. POL : OOL : OCL as $\mathrm{I} \cdot \mathrm{O}: \mathrm{I} \cdot 3: \mathrm{I} \cdot 9$.

Thorax normal. Legs with hind tarsus about as long as tibia, basitarsus longer than 3 following tarsal segments together. Spurs normal. Inner hind tibial spur longer than apical width of tibia as $\mathrm{I} \cdot 2: \mathrm{I} \cdot \mathrm{O}$. Claws with inner tooth about as long as end tooth, parallel with it but stouter at base.

Abdomen with ovipositor about as long as 3 basal hind tarsal segments. Sawsheath at about. $45^{\circ}$ out of alignment with basal plate and shorter than basal plate as $\mathrm{I} \cdot \mathrm{O}: \mathrm{I} \cdot 2$.

Punctation obsolescent on frons, which is shining; temples shining between shallow punctures separated by about two diameters from each other. Mesonotum and mesopleuron with denser punctures separated by about one diameter, but on the front lobes the interspaces between the punctures are dull, with fine surface sculpture and on the scutellum the punctures are shallow and with more widely shining interspaces. Abdomen dull with follicles and fine surface striations. 
Pubescence: Head and thorax with dense pubescence about as long as diameter of an ocellus, fuscous on the dark surfaces and colourless on the yellow surfaces. Abdomen likewise densely clothed all over with very short pubescence.

$\widehat{c}$ as 9 but lateral lobes of mesonotum entirely black, and abdomen with tergites 4,6 and 7 almost entirely, 3 laterally, posterior half of 8 and hypopygium and apical segments entirely yellow.

Antenna with 2oth segment about $\times 2$ broader than long. Sternite of 8 th abdominal segment with an apical fringe of strap-shaped setae; hypopygium normal, drawn out into a narrow tongue-like protuberance, slightly swollen apically, $9 \mathrm{~mm}$.

Holotype q. IsRael: near Jerusalem, Ejn, Karim, ro.iii.r959 (H. BytinskiSalz). B.M. (N.H.).

Paratype. Israel: Holou, I ðิ, 28.iii.I959 (H. Bytinski-Salz). B.M. (N.H.).

This new species is at once distinguishable from those previously known by its rich yellow markings. None of the other species have any tergites banded right across with yellow, or mesopleurum or scutellum yellow-flecked.

In structure the species are very similar, but the 22-segmented antenna may prove to be characteristic ( $C$. moricei Konow and $C$. scythicus Dovnar-Zapolskiǐ have 20 segments and $C$. modestus Dovnar-Zapolskir but I8).

\section{Characopygus scythicus Dovnar-Zapolskiř}

Turkey: Mersin, Gozne, I,800 m., I ㅇ, 2.vi. I960 (Guichard \& Harvey).

Previously known only from S. and S.E. Russia (Askamia-Nova, Sarepta and Orenburg).

\section{GEPHINI}

Attached to wild and cultivated Gramineae.

\section{Cephus pygmaeus (L.)}

Cephus tanaiticus Dovnar-Zapolskiǐ, syn. n.

C. notatus Kokujer, syn. n.

The descriptions of $C$. tanaiticus Dovnar-Zapolskir from S. Russia and $C$. notatus from Transcaucasia agree with melanic forms of this species that I have seen in Britain and elsewhere. Pest of corn and other cultivated grasses.

This species, apart from its introduction into eastern N. AMERICA, occurs throughout Europe, west of the Volga and Caspian and south of about $60^{\circ}$ lat. and also in N. Iran, Turkey, Syria and Israel.

Cephus brachycercus C. G. Thomson

TURKey: Samsun (5). I $\widehat{\delta}$.

Europe, Siberia and Turkey.

Cephus nigrinus C. G. Thomson

Syria: Meidan Ekbes (Konow, I89I).

Throughout EURope, SyrIA. 


\section{Cephus berytensis (Pic)}

$\uparrow$ Peronistilimorphus berytensis Pic, I9I6.

Type examined 24.iii.rg64. of. Abdomen and antennae beyond I3th segment are now missing It would appear to be a true Cephus, because the distance between the antennal sockets is approximately the same as the distance from a socket to the middle of the anterior tentorial fovea. Antenna swollen from I3th segment. Claws with minute inner tooth. Basal antennal segment yellow and legs entirely yellow except for trochanters and \pm coxae.

SYRIA (Beirut).

\section{Species incertae sedis}

Cephus nigricarpus André (Syria).

Cephus obscuriventris Pic, I9I8 (Lebanon) [Type lost. Pin and labels in Paris Mus., seen 24.iii.I964.]

Cephus politissimus Costa (Armenia).

\section{CALAMEUTA Konow}

\section{Key to E. Mediterranean Males and Females}

(2) Larger species (IO-I5 mm.) with more than one tergite entirely yellow and hind tibia with only one pre-apical spine $\quad . \quad$. $\quad . \quad$. $\quad . \quad$. 4

Smaller species (4-Io $\mathrm{mm}$.) with at most only one tergite entirely yellow or hind tibia with 2 pre-apical spines .

(3) Wings strongly infuscate. Head, thorax and legs entirely black. Abdomen almost entirely reddish yellow.

pygmaea (Poda)

Wings subhyaline. Head, thorax and legs \pm yellow-marked, abdomen banded yellow and black . $\quad . \quad . \quad . \quad . \quad . \quad . \quad . \quad . \quad$ idolon (Rossi)

5 (3) Scutellum impunctate. Abdomen in क entirely black; in ô with 4 middle tergites yellow-margined. Hind tibia yellow . . . . . pallipes (Klug)

Scutellum with definite punctures. Abdomen in o with at least apical tergite yellow, and $\hat{o}$ with middle tergites yellow-margined as in pallipes. Hind tibia yellow or \pm infuscate. (S.E. Europe and S. Siberia)

pravei (Dovnar-Zapolskǐ̌) 


\section{Calameuta filiformis (Eversmann)}

Cephus grombczevskii Jakovlev, syn. n. (Turkestan).

Cephus infernalis Dovnar-Zapolskiľ, syn. n. (Caucasus).

Cephus turanicus Dovnar-Zapolskiǐ, syn. n. (Turkestan bei Taschkent).

Calameuta amurensis Gussakovskiǐ syn. n. (Amur).

I have representatives of $C$. grombczevskii and infernalis named by Gussakovskii and they, together with $C$. amurensis, appear to be melanic forms of $C$. filiformis, C. infernalis retaining a yellow fleck on the side of the 5 th tergite and $C$. grombczevskii a yellow fleck on the 5th and 6th tergites; $C$. infernalis has, on the contrary, paler hind tibiae than $C$. filiformis. C. turanicus appears to be a paler form than $C$. filiformis.

In addition to Europe, Siberia, Transcaucasia, N. Iran and Syria, the species also occurs in LEBANON, where $I \hat{o}$ and $I q$ of the typical European form were collected by G. A. Mavromoustakis at Hammana, I6.v.I953 and I $\hat{o}^{\wedge}$ at Falouka, I7.v.I953.

\section{Calameuta haemorrhoidalis (F.)}

$\uparrow$ Cephus gracilicornis Konow, Caucasus.

Cephus diversipes Ghigi, Rhodes.

Trachelus syriacus Pic, Syria.

$\uparrow$ Calameuta festiva Benson, I954, Cyprus, syn. n.

Guichard and Harvey brought back Io $\hat{\delta}$, I 7 q of this species from GreECE, Thrace and various parts of Turkey, N.W., W., S.W., C., N. and N.E.; Istanbul (3); Bursa (I and 2); Mugla (7); Antalya (I3); Amasya ( 1 and 7 ); Ankara (I5 and 23); Samsun (6 and 7); Ersurum (8).

Most of them were collected in May and at various altitudes up to I,800 m., near the summit of Elma Dagi, Ankara on 2I.v.I960. The long 5th segment of the maxillary palp distinguishes this species from all other Cephinae, and enables a vast range of colour-pattern forms to be associated here, including the types of C. festiva and gracilicornis.

S.E. Europe, Turkey, Transcaucasia, Syria, Israel and W. Turkmen.

\section{Calameuta pygmaea (Poda)}

This is mainly a species of S.W. EURope and N. Africa but it extends through EGYPT to IsRAEL, where I $q$ was taken 20.iv. I953 at Wadi Ruaz, Beth Hale rem, Jerusalem (O. Theodor) and I 9 at Oqanim, 9.iv. I96I (Sandler).

\section{Calameuta idolon (Rossi)}

$\dagger$ Monoplopus apicicornis Pic, syn. $\mathbf{n}$.

Another species varying greatly in the amount of yellow colour on the head and thorax, so that it is not possible to draw any line of distinction from the form described as apicicornis with the head mainly yellow. Guichard and Harvey collected 
24 כै, I2 + in Turkey, C.: Ankara (4, II, I2 and I4) and Amasya (7), mostly from the flowery edges of a lake and streams.

N. Africa, S. Europe to Caucasus, Turkey, Iran, Syria, Lebanon and Israel.

\section{*Calameuta pallipes (Klug)}

A ô was collected in Turkey: Ankara, 800 m., 22.v.I960 (Guichard \& Harvey) and $I q$ on the Black Sea coast at Samsun, nr. Engiz, I7.v. I959 (Guichard).

Apart from these two records it has not been found outside Europe.

N. and C. Europe and Turkey.

\section{TRACHELUS Jurine}

\section{Key to Mediterranean Males and Females}

I Antenna with pre-apical segments at least $\times 2$ as broad as long. $6-9 \mathrm{~mm}$. .

- Antenna with no antennal segments $\times 2$ as broad as long. 7-14 mm. . .

2 (I) Hind tibia without pre-apical spine. ${ }^{t}$ with 3 apical sternites excavated and bearing modified setae. Pronotum \pm yellow-flecked. 6-9 $\mathrm{mm}$. libanensis (André)

Hind tibia with I pre-apical spine. $\delta$ without modified apical sternites. Pronotum flecked with yellow

judaicus (Konow)

3 (2) Larger species (Io-I4 mm.). Tibia \pm pale, abdomen often with some of the tergites yellow-margined apically

Smaller species (7-ro mm.). Legs entirely black. Abdomen black, with yellow lateral stripe or row of flecks but no tergites yellow-margined apically. Usually 2 pre-apical hind tibial spurs

tabidus (F.)

4 (3) Head capsule and mesonotum (apart from scutellum) entirely black. I-2 preapical tibial spurs present. Cross vein $3 \mathrm{rm}$ present in fore wing .

Head capsule, and mesonotum richly marked with yellow as also is abdomen. Hind tibiae without pre-apical apurs. Fore wing with vein $3 \mathrm{rm}$ missing. (ô unknown). I $2 \mathrm{~mm}$. (Astrachan) . . . . . tigris (Benson)

5 (4) Antenna, pronotum, scutellum and abdomen richly marked with yellow. IO-I 2 mm. (SPAIN and N. Africa) . . . . flavicornis (Lucas) Antenna, pronotum and scutellum entirely black, and abdomen with at most apical margins of some of the segments yellow. IO-I4 $\mathrm{mm}$.

troglodyta (F.)

\section{Trachelus judaicus (Konow)}

$\dagger$ Monoplopus judaicus Konow.

$\uparrow$ Monoplopus notaticollis Pic.

$\nmid$ Microcephus judaicus (Konow) Benson, I935.

This species is very similar to the next following, apart from the characters mentioned in the key, and Benson (I946) concluded that the species belonged to this genus despite its loss of the modified apical sternites in the male.

ISRAEL.

\section{Trachelus libanensis (André)}

$\dagger$ Ateuchopus armenius Konow, syn. $\mathbf{n}$.

In a series of over I00 specimens of this species from Cyprus, the pronotum varies from entirely black to mainly yellow and the development of punctures on the 
mesonotum likewise bridges the gap between the "species" libanensis and armenius. In the Transcaucasus the pronotum is said to be entirely black, whereas in Israel the pronotum is almost entirely yellow.

The species was found in TURKey, C.: Yozgat (I) on a flowery hillside at I,000 m. and at Mersin (I4) at I,600 m., near crops of corn.

Turkey, Cyprus, Syria, Lebanon and Israel.

\section{Trachelus troglodyta (F.)}

$\dagger$ Astatus tenuicornis Konow, I902, syn. n.

T. troglodyta has previously been recorded from only N. and C. EUROPE and is replaced in Transcaucasia by tenuicornis. The specimens collected from TURKEY, N. and N.E. at Rize (2) and Samsun (6 and 28) appear to be normal troglodyta. They were collected in swampy woods and the borders of marshes.

N. and C. Europe, to Turkey and Transcaucasia.

\section{Species incertae sedis}

Cephus (Fossulocephus) citriniventris Pic, I9I7 (Algeria).

\section{ARGIDAE \\ ARGINAE}

For keys to Palaearctic Arge species see Gussakovskiľ, I935.

\section{Arge ochropus (Gmelin)}

Tenthredo rosae L.; auctt. nec L.

Turkey, N.W., S., C., N., and N.E.: Bursa (2); Bolu (3); Antalya (5 and 6); Ankara (3); Sinop (4); Samsun (I0); Amasya (I, 2, 5, 6 and 7); Tokat (4); Adana (3 and 6); Trabzon (3 and 8); Erzurum (6). I2 $\hat{0}, 22$, from 4 .iv to I6. viii and at altitudes up to $\mathrm{I}, 700 \mathrm{~m}$.

Europe, W. and C. Siberia, Egypt, Israel, Lebanon, Syria, Turkey, Cyprus, Transcaucasia, N. Iran and Turkmen Republic.

\section{Arge simulatrix Konow}

Turkey, C. and E.: Ankara (32); Amasya (I and 2); Nigde (5); Gumusane (I). 4 oิ, 9 오.

Greece, Syria, Turkey and Transcaucasia.

\section{Arge frivaldzkyi (Tischbein)}

Turkey, W. and C.: Bursa (4); Ankara (2); Amasya (5 and 7). 6 ô, 4 ‥ Hungary, Greece, Turkey and Transcaucasia. 
*Arge beckeri (Tournier)

Turkey, E.: Erzurum (6). I $\widehat{o}$, I ․

S.E. Europe and Turkey.

\section{Arge pyrenaica (André)}

Turkey, N.E. and E.: Trabzon (I6); and Erzurum (4). I ô, I 9.

Mountains of N. Africa, Pyrenees, C. and S. Europe, Sardinia, Turkey, Transcaucasia, N. Ural, C. Asia, Mongolia.

Arge pagana (Panzer)

Europe, Transcaucasia, Siberia, Kamtchatka, Mongolia, Manchuria, N. ChINA and Japan.

\section{Arge carinifrons Enslin}

Transcaucasia.

N. IRAN.

$$
\text { Arge persica Gussakovskiǐ }
$$

\section{Arge impressifrons Konow}

Transcaucasia and N. Iran (Talysk).

\section{Arge cyanocrocea (Förster)}

Hylotoma syriaca Mocsáry, syn. n.

Benson (I958a) treated A. syriaca as a species distinct from cyanocrocea, as he found various venational and sculptural differences correlated with the blackened legs of syriaca. Much more material shows that these characters are not significantly correlated and that numerous intermediate combinations occur.

In the cooler parts of Europe all the tibiae and basitarsi as well as the hind femur are marked with yellow; in the warmer parts the legs from the front become more extensively blackened and in various parts of the Mediterranean from Spain to Lebanon occur forms with all the legs entirely or almost entirely black. On the S. Caspian Coast in N. Iran, D. B. Baker has collected a series with still more melanic tendencies: in $26 \hat{0}, \mathrm{I} 2$, , in addition to the legs being black, the wings show a range from normal colouring to almost entire infuscation; and $48 \hat{\sigma}, 9$ q have, in addition to entirely black wings, a deeply infuscate abdomen at most only obscurely brownish on the middle segments.

Turkey, N.W., S.W., S., C., N. and N.E.: Istanbul (2 and 3); Mugla (5 and ro); Mersin (6); Sinop (3); Amasya (I4); Samsun (9 and Io); Mersin (6); Rize (8); Artvin (3 and 6). 7 万人, 25 ‥ 
C. and S. Europe, Lebanon, Syria, Cyprus, Turkey, Transcaucasia, Iran and TURKMEN.

\section{Arge melanochroa (Gmelin)}

(Text-fig. I)

Hylotoma nigritarsis Klug, syn. $\mathbf{n}$.

In the E. Mediterranean, forms of this species often have the Ist tergite \pm infuscate and have been separated as a distinct species (nigritarsis) but every intergrade occurs in our series of over 150 specimens. The species is very similar to the following (scita) but can be distinguished by the black sawsheath in the $q$ with the large inner teeth, and in the $\widehat{o}$ by the entirely different form of penis-valve (Text-fig. I); in both sexes also by absence of a continuous longitudinal glabrous patch on the mesosternum.

Turkey, N.W., S.W., S., C., N., N.E. and E.: Istanbul (I, 2 and 9); Mugla (5); Mersin (6 and 7); Ankara (39, 53 and 54); Amasya (I, 5, 7 and I4); Tokat (3 and 4); Zongulduk (I); Sinop (3 and 4); Giresun (5); Erzurum (4 and 6). 6I o, 48 ․

C. and S. Europe, Syria, Cyprus, Turkey, Transcaucasia and Iran.

\section{Arge scita (Mocsáry)}

Hylotoma proxima André, syn. $\mathbf{n}$.

(Text-fig. 2)

$\uparrow$ Arge debilis Konow, syn. n.

A. zarudnyi Gussakovskiř, syn. n.

As in A. melanochroa, this species varies in the amount of infuscation of the Ist tergite, and also in whether the anastomosis of $M$ with $R$ in the fore wing is long or short, so that it is impossible in our long series from Cyprus and Turkey of over I20 specimens to segregate proxima and debilis from scita. From melanochroa this species is always to be distinguished in the $q$ by its pale sawsheath with only small inner teeth, in the $\delta$ by its very characteristic penis-valve (Text-fig. 2) and by the longitudinal glabrous patch on the mesosternum in both sexes.

Turkey, W., S.W., S., C. and E.: Bursa (69 and I4); Kutahya (II); Mugla (7); Hatay (3); Mersin (6); Nigde (5); Maras (4 and 5); Ankara (3, 4, I7, 53 and 54); Amasya (I, 3, 5, 6, 7 and 8); Tokat (3); Erzurum (4). 32 0, 24 o. It has been reared from a larva on Prunus amygdalus Batsch (Cyprus: Paphos, vi. I950 (Th. Shiakides).

Greece, Israel, Lebanon, Syria, Cyprus, Turkey, Transcaucasia, Iran and TURKMEN.

\section{Arge cingulata Jakoulev}

Avge turanica Kuznetzov-Ugamskiǐ, syn. n.

IRAN: Mazanderan, Panjak Rustaq, 860-I,I25 m., 7 ô, I 9 23.v.Ig66 and 7 ô, 5 ㅇ, 3.v. I967 (D. B. Baker).

TURKestan and Iran. 


\section{*Arge clavicornis seljuki ssp. n.}

Differs from the closely related $A$. clavicornis fuscipes Fallén in that the infuscate band below the stigma stretches right across the fore wing to the anal margin as in A. dimidiata Fallén.

Holotype +. Turkey: Trabzon, Zigana Dagi, I,400 m., I3.vii. I960 (Guichard \& Harvey). B.M. (N.H.).

Paratype q. Same data. B.M. (N.H.).

The species occurs throughout Europe, and in Turkey, Transcaucasia, Siberia and N. America.

\section{TRANSCAUCASIA.}

\section{Arge pallidinervis Gussakovskiř}

\section{Arge aurata (Zaddach)}

This species is very closely related to the European A. ustulata and clavicornis but, apart from its entirely dark legs, the pubescence on its head and thorax is golden instead of silvery.

Turkey, S. and E.: Nigde, Ciftehan, 900 m., 2 ऽ, 26.v. I960 (Guichard \& Harvey); and Erzurum (6). I + .

\section{Arge auripennis Konow}

S.E. Europe, Syria and Transcaucasia.

\section{Arge rustica (L.)}

Turkey, W., S., C., N., N.E., and E.: Izmit, Alem Deg, 600 m., I 9 , 30.vi. 966 (Demelt); Antalya (I3); Nigde (5); Ankara (4I); Amasya (6, I2 and I3); Sinop (2); Samsun (3); Giresun (2); Gumusane (4); Erzurum (6). 22 6ै, I8 .

Europe, Israel, Turkey and Transcaucasia.

\section{Arge pleuritica (Klug)}

Turkey, C., N., and E.: Aydin, Bozdogan, 2 ô, I2 $q$, iv. I950 (Plant Protection

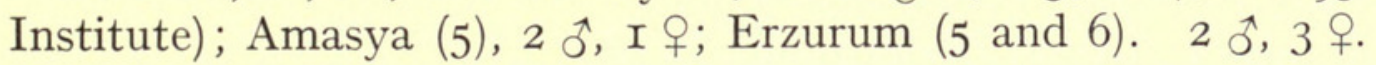

S.E. Europe, Turkey, Transcaucasia and Turkestan.

\section{Arge berberidis (Schrank)}

Turkey, S., C., N.E. and E.: Mersin (I3); Ankara (37 and 39); Giresun (5); Gumusane (I and 5); Erzurum (6). I ô, 9 9.

C. and S. Europe, Turkey and Transcaucasia.

\section{Arge nigripes (Retzius)}

Turkey, C., N.E., E.: Ankara (39); Giresun (2); Erzurum (6). 4 ô, 8 q.

Europe, Turkey, Transcaucasia and Siberia. 


\section{Arge ciliaris (L.)}

Europe, Transcaucasia, Siberia, Mongolia, Manchuria.

\section{Arge gracilicornis (Klug)}

Europe, Transcaucasia, Siberia, Japan.

\section{Arge enodis (L.)}

Turkey, C.: Ankara (35). I ô.

C. and S. Europe, Turkey, Transcaucasia, Siberia and Japan.

\section{Kokujewia ectrapela Konow}

Kokujewia clementi Zirngiebl, syn. n.

$\dagger$ Kokujewia palestina Benson, syn. $\mathbf{n}$.

The type of palestina was reared from a larva and the supposed differences of the sawsheath and tarsi of the adult were probably due to its teneral condition. $K$. clementi is surely a further synonym, as slight differences of colour are only to be expected.

Turkey, C.: Ankara, Elma Dagi, I,700 m., I ô, 28.vi.I959 (Guichard); the types of clementi were from Konya, Aksehir.

Israel, TURKey and Transcaucasia.

\section{STERICTIPHORINAE \\ Sterictiphora furcata (Villers)}

Hylotoma gastrica Klug, syn. n.

Schizoceros nigripes Konow, syn. $\mathbf{n}$.

Schizoceros henschi (Konow), syn. n.

Schizoceros bleusei Pic, syn. n.

Turkey, N.W., C., N. and E.: Istanbul (2 and 3); Ankara (39); Amasya (3 and 5); Zonguldak (I); Sinop (4); Erzurum (6). I ô, 9 ㅇ.

Europe, Syria, Turkey, Transcaucasia and Iran.

\section{Aprosthema tarda (Klug)}

TURKey: Sinop, I +, I8.vi.I959 (Guichard).

Gussakovskiǐ keys 45 palaearctic species of Aprosthema (and Psendaprosthema) but most of these are colour forms of a very few genuine species. In Europe and Turkey there are probably only two, tarda and melanura (see Conde, I934).

Europe, Israel, Turkey, Transcaucasia, Turkestan, Iran and Siberia.

\section{Aprosthema melanura (Klug)}

Europe to Caucasus, Turkestan, Iran and Siberia. 


\section{CIMBICIDAE}

\section{ZARAEINAE}

To distinguish the species see Benson, I95I : 39 .

\section{Zaraea aenea (Klug)}

Turkey, E.: Trabzon (3). I ㅇ.

C.E. Europe, Turkey and Transcaucasia.

\section{Abia sericea (L.)}

Turkey, S. and N.: Mersin (4); Samsun (I8). 3 ô, I 9.

Europe, Turkey and Transcaucasia.

\section{CIMBICINAE}

To distinguish the species see Gussakovskiî, I947.

\section{Pseudoclavellaria amerinae (L.)}

Turkey, E.: Gumusane (5). 5 ô, 2 ㅇ․

Europe, Turkey, Siberia and Corea.

\section{Palaeocimbex quadrimaculata (Müller)}

C. and S. Europe, Turkey and Israel.

\section{GORYNINAE}

\section{CORYNIS Thunberg}

Key to Males and Females

I Abdomen and often head and thorax marked with pale colour (yellowish white to orange or red). Claws sub-bifid or with small inner tooth . . .

Body entirely dark, brown or black, at most legs sometimes pale. Claws subbifid

2 (I) Face, scutellum, mesopleura as well as abdomen red-marked. Clypeo-frontal area convex above and gibbous in shape . . . . (sanguinea-group)

Pale colour yellow or yellowish white and usually less extensive. Clypeofrontal area flattened to form straight line in profile . . . . . .

3 (2) Mesonotum and tergites covered with widely spaced large punctures with the interspaces shining though pitted with numerous fine punctures . . .

Mesonotum in front, and tergites laterally, densely and coarsely punctured without shining interspaces; scutellum and tergites medially with shining interspaces scarcely larger than diameter of punctures.

Colour red with the following parts black: head apart from face below antennae, a medial and lateral fleck each side of mesonotum together with sunken parts thereof and metanotum, lower mesopleuron and mesosternum, 
coxae and base of femora, Ist tergite (except laterally) and fore and hind margins of and and 3rd tergites, together with most of sternites. Stigma and rest of wing venation brown. Antennae much longer than greatest eye measure, with club longer than distance between eyes in front. Hind ocelli about as far from eye-margin as from occipital carina (OOL $=$ OOCL). Claws with small inner tooth. Inner front tibial spur almost as long as basitarsus. Pubescence on parts of head, mesonoton and mesopleurum as long as diameter of front ocellus. ot not seen. $6 \mathrm{~mm}$. CANARY IsLands, Morocco and Tunis . . . . sanguinea (Snellen van Vollenhoven)

4 (3) Claws sub-bifid. Tibiae and tarsi reddish as femora; tarsi not infuscate apically. Hind ocelli one and one-half times further from eye-margin as from occipital carina (OOL > OOCL).

Colour as in sanguinea but the 2 nd -5 th tergites are marked with black medially though progressively less. ot not known. Algeria and TripoliTANIA .

. †semisanguinea (Pic, I9I6)

Claws with only minute inner tooth. Tibiae and base of tarsi yellowish white in contrast to the red apex of the femora, and the apical tarsomeres infuscate. Hind ocelli about as far from eye-margin as from occipital carina (OOL $=$ OOCL).

Otherwise coloured as in semisanguinea but that the lateral and medial dark flecks on the mesonotum are much enlarged and partially joined and the scutellum is infuscate laterally. $6 \mathrm{~mm}$. $\sigma^{t}$ only. Holotype $\sigma^{t}$. Israel: Vadi Ajram, 7.v.1954 (H. Bytinski-Salz) (in B.M.). IsRael haematica sp. n.

5 (2) Antenna not longer than greatest measure of eye, and club often shorter than distance between eyes in front. Face very flat: clypeo-frontal area below scarcely raised above level of inner orbits. Frontal area of head and thorax almost glabrous; pubescence on post-ocellar region of head much shorter than diameter of front ocellus. Claws sub-bifid. Inner front tibial spur about three-fourths as long as basitarsus.

Antenna at least about one-fourth longer than greatest measure of eye and club often longer than distance between eyes in front. Face with clypeo-frontal area with declivous sides raising it above the level of the inner orbits. Head and thorax pubescent all over and in part at least almost as long as diameter of front ocellus. Claws with small inner tooth or sub-bifid. Inner front tibial spur not more than about two-thirds as long as basitarsus (except in citrina)

6 (5) Face below antenna, fleck on mesonotum in addition to scutellum and mesopleuron as well as tegula and pronotum yellow. Thorax with shining interspaces between punctures at least as large as punctures on mesopleura and sides of mesonotum. Post-ocellar region? $5-6 \mathrm{~mm}$. S. and E. Europe (N. to Leningrad) and S.W. Siberia . . . . $\quad$ +

Head with only clypeus, thorax with only tegula and pronotum, \pm yellow. Thorax very densely punctured, without shining interspaces as large as punctures on mesopleura or sides of mesonotum. Post-ocellar region convexly raised above level of hind ocelli. 6-7 mm. S.E. Europe, E. MediTERRANEAN and TURKESTAN concinna (J. P. E. F. Stein)

7 (5) Pronotum and face below antennae \pm yellow, or malar space at most twothirds as long as diameter of front ocellus in $ᄋ$ and less than one-half in $\hat{\sigma}$.

Pronotum and often face below antennae black. Malar space at least about as long as diameter of front ocellus in 9 and two-thirds in $\widehat{\delta}$.

Claws with only small inner tooth.

8 (7) Claws bifid

- Claws with only small inner tooth

9 (8) Fleck on mesopleuron, and abdomen with continuous bands on tergites I and 3 or 4 to 7 , as well as all the sternites, yellowish white. Mesonotum with 
shining surface between large widely-spaced punctures. Hind ocelli further apart than from nearest eye-margin : POL $>$ OOL. $7-8.5 \mathrm{~mm}$. N. AFricA

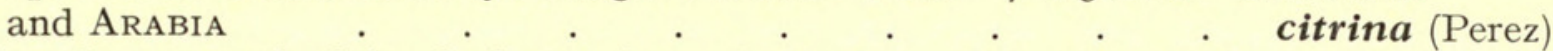

- Mesopleuron and abdominal sternites all black, and tergites with at most continuous yellow band on 7 th segment. Mesonotum dull with rough surface sculpture between the punctures. Hind ocelli as far apart as from nearest eye margin : POL $=$ OOL. 8.5-9 mm. Portugal, Spain, Algeria

dusmeti (Konow)

Io (8) Malar space as long as diameter of front ocellus in 9 and two-thirds as long in c. Pubescence on mesopleura longer than diameter of front ocellus. E. Mediterranean . . . . . . . . . †orientalis (Konow)

Malar space only about two-thirds as long as diameter of front ocellus in $q$ and less than half in $\hat{\sigma}$. Pubescence on mesopleura much shorter than diameter of front ocellus. Spain, Algeria . . . . . . . . jucunda (Klug)

I I (7) Pubescence on mesonotum and mesopleura only about half as long as diameter of an ocellus. Hind ocelli closer to occipital carina than from nearest eyemargin

Pubescence on mesonotum and mesopleura in part longer than diameter of an ocellus. Hind ocelli about as far from occipital carina as from nearest eyemargin.

[POL $>$ OOL. Hind ocelli about twice their own diameter from occipital carina.] N. Africa, C. and S. Europe, Transcaucasus and Ukraine

crassicornis (Rossi)

I2 (II) Clypeo-frontal area entirely black and its medial groove extends only onefourth or one-third of way to antennae. POL $=$ or $>$ OOL. Hypopygium (ㅇ) excised on hind margin each side of middle

Clypeo-frontal area marked in front with yellow, and its medial groove extends half way to antennae. POL $<$ OOL. Hypopygium (o) only slightly emarginate on hind margin each side of middle.

Hind ocelli about twice their own diameter from occipital carina. E. Mediterranean .

$\dagger$ frontina (Konow)

I3 (I2) POL > OOL. Hind ocelli twice their own diameter from occipital carina.

Subcosta of fore wing infuscate except at extreme base. E. Mediterranean

lateralis (Brullé)

$\mathrm{POL}=\mathrm{OOL} . \quad$ Hind ocelli about one and one-half times their own diameter from occipital carina. Subcosta of fore wing brown except at extreme apex. SPAIN, N.W. AFrica . . . . . . mauritanica (Gussakovskiǐ)

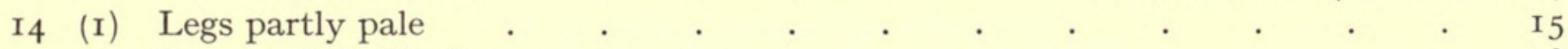

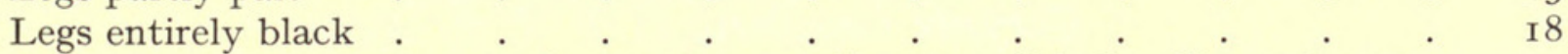

I5 (I4) Pubescence on mesonotum at least as long as diameter of hind ocellus and \pm upstanding. Clypeo-frontal area convex and gibbous above. Malar space less than half as long as diameter of front ocellus

Pubescence on head and thorax much shorter than diameter of hind ocellus and prostrate. Clypeo-frontal area with the middle flattened so that it appears as a straight line in profile. Femora mainly black. 7-1o $\mathrm{mm}$. Malar space more than half diameter of front ocellus. $\delta$ apical tergites unmodified. E. Mediterranean . . . . . †similis (Mocsáry)

r6 (I5) Pubescence on mesonotum and head only about as long as diameter of hind ocellus and pubescence on abdomen much shorter than this. Femora black only basally. Tergites scarcely arched longitudinally . . . .

Pubescence on mesonotum, head and abdomen very coarse and about as long as $4^{\text {th }}$ antennal segment. Femora mainly black. Tergites strongly arched longitudinally. $\delta$ 8th tergite with apical triangle bearing dense fine pubescence. S.E. Europe and E. Mediterranean .

†kruperi (J. P. E. F. Stein) 
I7 (I6) Mesopleura very densely punctate without shining interspaces. $\widehat{\imath}$ with unmodified 7 th and 8 th tergites. E. MEditerRanean . + †reticulata (Benson)

Mesopleura less densely punctate, so that there are some shining interspaces in the middle as large as punctures. $\delta 7$ th and 8 th tergites with an apical medial triangular area bearing dense long fine hairs. Algeria †andrei (Konow)

I8 (I4) Clypeo-frontal area convex above and concave below . . . . . . . $\quad$. 19

- Clypeo-frontal area flattened medially, slightly concave throughout with raised lateral margins.

+ hypopygium only slightly emarginate laterally. $\sigma^{\star} 7_{\text {th }}$ tergite with medial apical longitudinal line densely pubescent. 5-6 mm. long. S. Europe and E. Mediterranean

italica (Lepeletier)

I9 (I8) Clypeo-frontal area evenly convex above and slightly concave below, showing a curved line in profile. Pubescence of head, thorax and abdomen grey. ot apical tergites unmodified. 5.5-7 mm. . . . . . .

Clypeo-frontal area strongly convex above, gibbous in shape strongly depressed below, angular in profile. Pubescence of head, thorax and abdomen fuscous. of $7^{\text {th }}$ tergite with a medial apical triangular area with dense pubescence. 4.5-6 mm. long. S.E. Europe . . . †atricapilla (Mocsáry)

20 (19) Malar space about as long as diameter of front ocellus. + hypopygium with hind margin excised each side. Punctation on mesonotum coarser and more irregular. C. and S. Europe and Turkey . . obscura (Fabricius)

Malar space not more than one half as long as diameter of front ocellus. 우 hypopygium only slightly emarginate each side. Punctation on mesonotum much finer and more regular. S.E. Europe, E. Mediterranean to N. Iran

†caucasica (Mocsáry)

\section{Corynis haematica sp. $\mathrm{n}$.}

Description and comparison with related species is included in the key above. ISRAEL.

\section{$\dagger$ Corynis orientalis (Konow)}

Syria, LEbANON, IsRAEL and IraQ.

\section{Corynis concinna (J. P. E. F. Stein)}

Amasis sarta Kuznetzov-Ugamskiř, syn. n.

A. bleyli Muche, I964, syn. n.

Turkey, S., C. and E.: Mersin (6). I ㅇ. Cankiri, Isik Dag, I,200 m. I $q$, 25.vi.rg66 (Demelt Coll.); Amasya (5, 6 and 7). I7 + ; Erzurum (3 and 4). 4 ‥ At flowers of Potentilla hirta.

S.E. Europe, Turkey and Transcaucasia.

\section{Corynis lateralis (Brullé)}

Turkey, C. and E.: Ankara (4I); Amasya (3 and 7); Artvin (2). I ô, I7 ㅇ.

S.E. Europe, Turkey, Transcaucasia and S. Ural. 


\section{$†$ Corynis frontina (Konow)}

Turkey, S., C., N., N.E. and E.: Mersin (7); Amasya (I, 2, 3, 5 and 7); Ankara (4I); Samsun (I0); Artvin (2); Gumusane (I4). 39 ડิ, 27 ‥

Turkey and Transcaucasia.

\section{Corynis citrina (Pérez)}

Arabia: Bahrein Island in Persian Gulf, I ㅇ, 4.iii.r936 (J. Fernandez).

Algeria, Tunisia, Tripolitania and Arabia.

†Corynis similis (Mocsáry)

Ionian Islands, Crete, Cyprus, Syria and Israel.

$\dagger$ Corynis kruperi (J. P. E. F. Stein)

Amasis enslini Maidl, syn. $\mathbf{n}$.

Turkey, W. and C.: Bursa (3); Amasya (I4). 3 ô, 3 ‥

Balkans, Turkey, Cyrenaica and Tripolitania.

* + Corynis reticulata Benson, I954

Turkey, C.: Nigde, Ulukisla, I ㅇ, I6-20.v.I955 (Seidenstücker).

Turkey and IsRael.

\section{Corynis italica (Lepeletier)}

Turkey, W. and C.: Bursa (9); Amasya (3, 7 and 9). 8 of, 8 ․

S. Europe and Turkey.

\section{†Corynis caucasica (Mocsáry)}

Turkey, N.W., C. and E.: Edirne (I); Amasya (2, 3, 7 and 9); Trabzon (3 and I5). 26 万ิ, 24 ㅇ.

S.E. Europe, Turkey, Transcaucasia and Iran.

Corynis obscura (Fabricius)

Turkey, N.E., and E.: Trabzon (I3); Rize (8); Erzurum (I0). I ô, I $q$.

Europe, Turkey and Transcaucasia.

\section{TENTHREDINIDAE}

The notes on the species of this family are intended for use in comparison with the keys given in Benson, $\mathrm{I} 95^{\mathrm{I}-58}$. 


\section{SELANDRIINAE}

For a recent revision of the Palaearctic species of this subfamily see Zhelochovtsev, I95I.

\section{Thrinax caucasica Schaposchikov}

This species is closely similar to T. mixta Klug, but differs in that the edge of the pronotum, tegulae and venation at base of fore wing are red instead of yellowish white, that on the legs the coxae and trochanters are black as well as \pm the femora and tibiae, and the frontal area of the head is more transversely wrinkled than in mixta.

Turkey, N.E.: Trabzon (I7). 2 ô, 5 ㅇ.

Turkey and Transcaucasia.

\section{T. macula (Klug)}

C. and N. Europe and Transcaucasia.

\section{Strongylogaster lineata lineata (Christ)}

Turkey, N.W., N. and N.E.: Istanbul (2); Sinop (2); Samsun (I9); Rize (5). 9 ㅇ. Europe, Turkey, Transcaucasia, Iran, Siberia to Japan.

\section{$\dagger$ Strongylogaster lineata cypria Benson, I954}

This form, only known from Cyprus and Lebanon, has almost entirely yellow legs and entirely black antenna and epipygium (the typical subspecies has blackbased femora, and the two basal antennal segments and the epipygium brown).

\section{$T$. coronatus Klug, syn. $\mathbf{n}$.}

\section{Aneugmenus padi (L.)}

The only difference that I can discover between $A$. padi and $A$. coronatus is that $A$. coronatus has a small white fleck in the middle of the apical tergites in the + . As these two forms occur together over the same range, together with intermediate forms which can only be ascribed arbitrarily, it is unlikely that they are specifically distinct.

Only one form of $\hat{\jmath}$ is known and this has a large yellow fleck covering the middle of the middle tergites and another covering most of the sternites. The $\delta$ is also remarkable in having a sinus sexualis cutting transversely deeply into the 7 th tergite. The male has occasionally been found in Britain, where however the species is at least almost entirely parthenogenetic. In the Mediterranean region, males are more numerous than females.

Turkey, N.W., S., N. and N.E.: Istanbul (2 and 3); Mersin (6); Tokat (I); Samsun (29); Rize (5). I8 ठ, I5 우.

Lebanon: Felouka, 5 s, I7.v.r953 (G. A. Mavromoustakis).

Europe, N. Africa, Turkey and Siberia (introduced into N. America). 


\section{Aneugmenus oertzeni (Konow)}

This species, which I have never seen, is distinguished from $A$. padi by its untoothed tarsal claws. From A. fuerstenbergensis it is distinguished in the 0 by having the 6th tergite emarginate apically and a transverse groove (sinus sexualis) across the 7 th tergite (as in $A$. padi) and the tergites yellow from the 3 rd segment; and in both sexes by the shining surface of the tergites which in A. fuerstenbergensis are dull with transverse striations.

Crete, Turkey and S.E. Europe.

\section{Birka cinereipes (Klug)}

Melisandra cinereipes (Klug) Benson.

Turkey, N.: Balu (I). I + .

N. and C. Europe, Turkey and Transcaucasia.

\section{Mesoselandria morio (Fabricius)}

Melisandra morio (Fabricius) Benson.

Turkey, C., N., and N.E.: Ankara (39); Sinop (4); Trabzon (3, 7 and 9); Rize (I and 6). 8 o.

Europe, Turkey, Transcaucasia and Siberia.

\section{Selandria serva (Fabricius)}

†Selandria serva fuscitarsis Benson, I954, syn. n.

Turkey, N.W., C., N. and N.E. and E.: Istanbul (3 and I0); Ankara (I5, 34, 39 and 40); Tokat (I and 3); Samsun (5, 7, I0, 20 and 24); Trabzon (8); Gireson (3); Erzurum (5). Plentiful, 9.v-6.ix, from altitudes up to I,300 m. in Karagol lake, Ankara. The form with black tarsi does not represent a distinct subspecies as numerous intermediates occur. Gramineae and Cyperaceae.

Europe, Turkey, Transcaucasia and Siberia.

\section{Brachythops flavens (Klug)}

Europe, Transcaucasia, Siberia, N. America.

\section{Loderus eversmanni (Kirby)}

Turkey, N., N.E. and E.: Samsun (5); Trabzon (4); Gumusane (I3); Erzurum (I3). I,245-2,000 m., 75 今, I5 +. Equisetum.

Europe to Caucasus and Turkey, Siberia to Japan, and N. America (polytypic species). 


\section{DOLERUS Panzer}

In the list which follows, a key is given to the species of the picipes-ciliatus-group.

\section{Loderus vestigialis (Klug)}

Turkey, N.E. and E.: Trabzon (3, 4 and I7); Gumusane (I0); Rize (2). 500I,800 m., 34 ô, II ㅇ. Equisetum.

Europe to Caucasus and Siberia to Japan and N. America (polytypic species).

\section{Dolerus germanicus (Fabricius)}

Turkey, C., N.E. and E.: Amasya (2); Trabzon (7 and 9); Rize (5); Gumusane (3); Erzurum (3, 5 and ro). Trabzon and Rize at sea level. 56 o, 83 ㅇ, I9.iv.20.iv.I959; 40 ô, 24 + , 24.viii.I959. Erzurum and Gumusane, I,700-2,000 m. I9 ô, 4 +, 3 I.V.-I.vi.I962.

Europe and temperate Asia. (polytypic species).

The three series from N.E. TuRkEY represent the spring and summer flights of a double-brooded mountain form. The lowland form would appear to represent D. germanicus meridianus Zhelochovtsev, distinguishable from the mountain form, the S. European etruscus, through its yellow labrum and, in the summer females, through its yellow clypeus also. It is not clear whether the lowland and mountain forms are discrete races, kept apart by altitude and differing flying-seasons, or whether blending occurs in intermediate altitudes and seasons. Every intergrade occurs between the two European forms: germanicus of W. and C. EUROPE with its hind legs more extensively black than its front legs and frequently with black marks also on front mesonotal lobe and scutellum; and etruscus Klug of C. and S.E. EUROPE with its hind legs more extensively yellow than its front legs, and the front mesonotal lobe and scutellum usually entirely yellow.

It would therefore seem very unlikely that the forms $D$. germanicus germanicus, D. germanicus etruscus and D. germanicus meridianus are discrete subspecies.

\section{$\dagger$ Dolerus melanoptera Konow}

Very closely similar to the preceding but larger (I0-II $\mathrm{mm}$. instead of 7-9 $\mathrm{mm}$.) with head more swollen behind eyes, temples more sparsely punctured, with occipital groove and carina less developed and hind femur and tibia entirely yellow. The $\delta$ in lacking the black flecks on the apical tergites differs from the form of germanicus in E. Mediterranean (some $\hat{\delta} \hat{\jmath}$ of germanicus in Italy and Spain lack these flecks).

From $D$. hispanicus it is distinguished by its partly pale legs and deeply excised clypeus (to depth of at least half the total length of clypeus).

Turkey, N.W., C. and N.: Edirne (I); Ankara (I5, 35 and 36); Amasya (2 and 7); Samsun (20). 24 0ิ, I3 우.

S.E. Europe and Turkey. 


\section{$\dagger$ †olerus hispanicus Mocsáry}

Dolerus geniculatus Lepeletier, I823, nec Geoffroy, I785, syn. n.

$\dagger$ Dolerus nigriceps Konow, I891, syn. n.

Dolerus africanus Forsius, I919, syn. n.

This species is similar to D. germanicus in general form and sawsheath, but is larger, with very sparsely punctured head and mesonotum, with poorly developed temporal furrows on head, and the rst tergite and sawsheath in the $q$ are pale, and the legs entirely black. From both germanicus and melanoptera it is distinguished by its less deeply excised clypeus (less than half the total clypeal length). The $\hat{o}$, like the + , has the mesonotum mainly yellow and the apex of the abdomen unmarked with black. The palest forms occur in Algeria, where the whole thorax and abdomen above, including Ist tergite in both $o^{t}$ and $q$, can be yellow, and only the meso- and metasternum black, but usually the scutellum and the sunken surrounding parts are \pm black.

Turkey, C.: Amasya, 500 m., I ठิ, 2 + , 22.v.-6.vi.I959 (Guichard \& Harvey).

N.W. Africa, Spain, Turkey, Transcaucasia and N. Iran.

Dolerus aericeps C. G. Thomson

Europe and Transcaucasia.

*Dolerus anticus seljuki ssp. n.

In the 9 , this race is distinguished from the typical race in that the lateral mesonotal lobes are entirely reddish yellow except where they meet medially. In colour therefore these specimens resemble $D$. madidus f. schulthessi except that the mesopleuron is entirely black. In form of saw, sawsheath with curved setae, and antenna with 8th segment only twice as long as wide, they are clearly distinguished from $D$. madidus. The $\hat{\sigma}$ is distinguished from typical $D$. anticus by having the 2 nd and 7 th tergites unmarked with black.

Holotype +. E. Turkey: Gumusane, Bayburt, I,600 m., 26.v. I962 (Guichard \& Harvey); B.M. (N.H.).

Paratypes. Turkey: N.W., N., N.E. and E.: Edirne, I ㅇ, 6.v.Ig60 (Guichard \& Harvey); Samsun, Lake Ladig, 800 m., I +, 26.vii.I959 (Guichard); Erzurum, Ovacik, 2,000 m., I ô, 30.v.I962 (Guichard \& Harvey); Gumusane, Bayburt, I,600 m., I ㅇ, 26.v. I962 (Guichard \& Harvey). B.M. (N.H.).

The species not previously recorded outside Europe.

\section{Dolerus triplicatus triplicatus (Klug)}

This subspecies is distinguished from steini thus: (I) ô colour pattern is different from the $q$, the thorax and Ist tergite being entirely black; and $(2)+$, though similar to steini, in having a reddish yellow thorax with a black fleck on each of the mesonotal lobes and a large fleck on the underthorax, covering the mesosternum and much of the mesopleura. This fleck does not reach the front edge of the mesepisternum, and 
the depressed lateral parts of the mesonotum are not infuscate. This subspecies would appear to be the continental part of an atlantic/continental subspecies pair which it forms with steini: these two subspecies overlap in TURKEY.

Turkey, N.W., C. and E.: Edirne (I); Ankara (I3); Gumusane (I3); Erzurum (7); I,000 to I,800 m., 43 ô, 7 ㅇ.

Sweden, Germany, Czechoslovakia, Austria, and N.W., C. and E. Turkey.

\section{Dolerus triplicatus steini (Konow, I885)}

Dolerus triplicatus (Klug); Benson, I952 nec Klug.

Dolerus triplicatus steini (Konow); Benson, I966.

This subspecies is the atlantic counterpart of an atlantic-continental subspecies pair which it forms with the preceding subspecies. It is distinguished by the $\hat{0}$ and $q$ having the same colour pattern, which differs from that of the triplicatus $o$ in that the black fleck on the underthorax reaches right to the front of the mesepisternum and that depressed lateral parts of the mesonotum are \pm infuscate (see fig. 4 in Benson, I966).

Turkey, N.E.: Trabzon, Soganli Gecidi, 2,600 m., I ô, 27.vi.Ig62 (Guichard \& Harvey); Rize, Sivrikaya, I,700 m., I ㅇ, 3.vi.I962 (Guichard \& Harvey).

England, Switzerland, Italy and N.E. Turkey.

Dolerus puncticollis C. G. Thomson

Turkey, N. and E.: Samsun (I2 and I5). 3 ô, 3I + , I,600-2,390 m., 2-II .iv. I959. Rize (8); Gumusane (3, I0); Erzurum (5, I2 and I4). 26 6, 25 क , at sea level, 23.v to $3 \cdot$ vi.I962.

Europe, Israel and Turkey.

\section{[Dolerus gonager $(\mathrm{F}$.}

(Text-fig. 7)

Turkey, N.W.: Istanbul, Belgrat Orman, I §ૈ, 23.iii.I962 (Guichard \& Harvey). EUROPE].

\section{*Dolerus montivagus sp. n.}

(Text-figs. 4, 9)

ㅇ․ Black except for the red knees (the extreme apex of all the femora and extreme base of all the tibiae). Pubescence silvery. Wings subhyaline with black venation. Length: 9-Io mm.

Head: subparallel-sided behind the eyes, which are separated above from the occipital margin by about their own length. Malar space about one-third of inter-antennal line. Clypeus broadly and shallowly emarginate to a depth of only about one-fifth of the clypeal length. Antenna with 8 th segment about $\times 5$ as long as basal breadth and 3 rd segment longer than greatest measure of an eye as ( $\mathrm{I} \cdot 0$ : 09). Punctation coarse with several large shining interspaces on temples and notably a large spot as large as 2 or 3 ocelli adjoining each of the lateral ocelli. Occipital furrows not very clearly marked above. 
Thorax: Mesonotum coarsely and rather irregularly punctured but shining between the punctures; large sparsely punctate shining areas occur each side of the middle line of the front lobes, most of the front and middle of the lateral lobes and the front and middle of the scutellum; post-tergite of scutellum shining without punctures or microsculpture and longer than the shortest measure of a cencher. Mesopleuron coarsely and densely punctured, without interspaces as large as a puncture. Mesosternum with only very shallow fine scattered punctures. Legs normal, with hind tarsus about five-sixths as long as a tibia. Wings normal.

Abdomen: Normal but with transversely alutaceous surface sculpture obsolescent on the ist and middle of the and tergite. Sawsheath in dorsal view long and narrow, but with apical setae much as in $D$. puncticollis (Text-fig. 4).

Pubescence silvery all over and up to about as long as $\times 2$ diameter of an ocellus on head and thorax, obsolete on the 2 nd, 3 rd and 4 th tergites and middle of ist tergite.

$\hat{0}$ as $q$ but head contracted slightly behind eyes, which are separated above from the occipital margin by little more than their own shortest measure, 8th antennal segment only about $\times 3.5$ as long as its basal breadth. Abdomen more pubescent on ist and middle of 2 nd and $3^{\text {rd }}$ tergites, the tergites beyond $4^{\text {th }}$ lacking even the mid-dorsal base line; penis-valve (Textfig. 9).

Holotype ㅇ. N.E. Turkey: Trabzon, Soganli Gecidi, 2,600 m., 26.v.Ig62 (Guichard \& Harvey). B.M. (N.H.).

Paratypes. N.E. Turkey: $3 \hat{\jmath}$ (with same data as holotype); Trabzon, Zigana Gecidi, I,650 m., I3 ô, 22.v. I962; Trabzon, Hamsikoy, I,245 m., I ô, I + , 2324.v.I962; Rize, Sivrikaya, I,700 m., I ô, I +, 3.vi.I962; and Erzurum, Tortum, I,550 m., I + , Io.vi. I962 (Guichard \& Harvey). Total 4 ㅇ, I8 ơ. B.M. (N.H.).

This species has the sparse punctation of $D$. gonager on the mesonotum, but the narrow sawsheath bears setae more like those of $D$. puncticollis: from both these species though it differs in having a scarcely emarginate clypeus, longer antennae in $q$ (in neither $D$. gonager nor $D$. puncticollis $q$ is the 3 rd antennal segment clearly longer than an eye), and in $\hat{\delta}$, absence of bare hairless mid-dorsal line on abdomen from 4 th tergite, apart from differences in the penis-valve.

\section{The PICIPES-CILIATUS-GROUP}

In S.E. Europe, Asia Minor and Transcaucasia there occurs a group of species related to the two last species (Dolerus gonager F. and puncticollis Thomson) but in which the female sawsheath is sharply expanded behind in dorsal view (see Benson, I95I-58, fig. I98), the legs are often red about the knees (the joint between the femur and the tibia) and the temples have an impunctate spot $c . \times 3$ diameter of an ocellus adjoining the postocellar area each side. The males are under $9 \mathrm{~mm}$. and have: (I) either the lateral mesonotal lobe punctate at least behind, or infuscate pubescence on the head, and (2) either very densely pubescent tergites without a bare medial line or a clypeus with a much-reduced medial front marginal excision (to less than one-third of total clypeal length). In three of the species the females are \pm brachypterous with correlated changes in the mesonotum (flattening and shortening of lobes with obsolescence of suture dividing front pair and shortening of post-tergite of scutellum). 


\section{Key to Males and Females}

I Wings hyaline and fully-developed in $\hat{\sigma}$ and ㅇ. Clypeus apically broadly emarginate to a depth of at least one-third of its total length, with the lateral lobes narrower than the medial emargination. Pubescence on head and thorax silvery

Wings infuscate and often brachypterous in ㅇ. Either clypeus with a narrow and shallow excision apically (to a depth not exceeding one-third of its total length and leaving obtuse or truncate lateral lobes) or pubescence on head and mesonotum infuscate

2 (I) Legs not red about the knees (joint between femur and tibia). Head behind the eyes slightly swollen, longer than shortest measure of eye and with occipital furrows obsolescent. $\delta$ abdomen lacks the medial bare line through the pubescence on tergites 3-8; penis-valve (Benson, I95I-58, fig. 240). Larger species: 7-9 mm. EUROPE

picipes Klug

Legs red about the knees. Head slightly contracted behind eyes, not longer than shortest eye-measure and with occipital furrows clearly developed. ot abdomen with medial bare line through pubescence on tergites 3-8; penisvalve (Text-fig. 5). Smaller species: $7-8 \mathrm{~mm}$. IRAN

hyrcanus $\mathrm{sp} . \mathrm{n}$.

[Dolerus vernalis Ermolenko, I964 (unique 우) (Ukraine) would run here and may be synonymous, but has red on front and middle knees limited to apex of femur.]

3 (I) Either clypeus excised medially in front to a depth less the diameter of the front ocellus, or pubescence on head and wings silvery. $q \pm$ brachypterous

Clypeus broadly emarginate in front to a depth of almost one-third of its total length. Upper head and wings with infuscate pubescence. Wings fullyformed in both sexes.

Legs red on the knees. Penis-valve (Text-fig. 6). S.E. Europe and Transcaucasia . . . . . . . . . . kokujewi Konow

4 (3) + wings less than one-half as long as abdomen. At least $\hat{o}$ with infuscate pubescence on upper head and wings . $\quad . \quad$. $\quad . \quad . \quad . \quad$.

ㅇ wings much more than one-half as long as abdomen. Pubescence on head and wings silvery in $\sigma^{t}$ and + . . S.E. EUROPE . . $\quad$ subalatus Kirensky, I926

5 (4) Legs entirely black. क with infuscate pubescence on head and wings. Pubescence on mesopleura shorter than on head and mesonotum, where it is as long as 2nd antennal segment. Greece (Mt. Parnassus, 2,00o m.) (ô un-

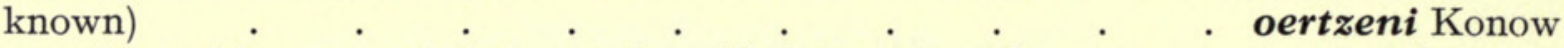

Legs with red knees. $\delta$, but not ${ }$, with infuscate pubescence on head and wings; + with pubescence on mesopleura as long as that on head and mesonotum, where it is about as long as 2nd antennal segment. S.E. Europe and Transcaucasia

ciliatus Konow

\section{Dolerus picipes Klug}

Europe, Turkey and Transcaucasia.

\section{Dolerus kokujewi Konow}

(Text-fig. 6)

Turkey, N.E.: Trabzon, Zigana Gecidi, I,650 m., I §̋, 2.v.I962 (Guichard \& Harvey).

S.E. Europe, Turkey and Transcaucasia. 


\title{
Dolerus hyrcanus sp. n.
}

\author{
(Text-figs. 3, 5)
}

o. Black with the knees red (the apical half of the femur and basal fourth of the tibia); pubescence silvery; wings hyaline with black venation. Length $8-9 \mathrm{~mm}$.

Head: slightly contracted behind eyes which are separated above from the occipital margin by about their own shortest measure. Malar space about one-half of inter-antennal line. Clypeus broadly emarginate in front to a depth of about one-third of its total length and strongly arched transversely. Antenna with 8th segment about $\times 4$ as long as its basal breadth. Punctation coarse and without interspaces in front of ocelli but the temples adjoining the postocellar region each side have an impunctate area as large as 2 to 3 ocelli. Occipital furrows clearly marked.

Thorax: front lobes of mesonotum coarsely punctured laterally without interspaces but with the middle half shining with shallow sparse punctures; middle lobes shining with sparse shallow punctures on the front half, widely spaced becoming denser behind; scutellum densely punctured except in front and \pm along middle line, and with its post-tergite longer than the shortest length of a cencher and obliquely striated with rugulae. Mesopleura coarsely punctured but with a few impunctate spots in the middle up to about twice the diameter of a puncture. Mesosternum with only very shallow fine scattered punctures. Legs normal with hind tarsus about five-sixths as long as tibia. Wings normal.

Abdomen normal with tergites transversely alutaceous; penis-valve as in Text-fig. 5 .

Pubescence silvery all over; on head and thorax up to about $\times 2$ diameters of ocellus; abdomen with tergites $\mathrm{I}-3 \pm$ glabrous laterally, rest of tergites densely clothed except for base medial line.

ㅇ as $\hat{\sigma}$ except as follows: 8 th antennal segment only $\times 3$ as long as broad at base; hind tarsus only about two-thirds as long as tibia; ovipositor longer than hind femur; sawsheath in dorsal view incrassate apically, where it is twice as broad as at base (Text-fig. 3). Saw as in D. picipes.

Holotype ô. Iran: Mazandaran, Chalus-Chahsavar coast, 23.iii.Ig66 (D. B. Baker). B.M. (N.H.).

Paratypes. Same locality, I9 ô, 3 + , 25.ii-28.iii (D. B. Baker). B.M. (N.H.).

The $q$ is distinguished from other species of the picipes-ciliatus group in the key above. The $\hat{\sigma}$ penis-valve (Text-fig. 5) is unlike that of any other known species but is perhaps most like that of $D$. puncticollis (cf. Benson, I95 I-58, fig. 230).

\section{Dolerus nigratus (Müller)}

Europe and Turkey (Bytinski-Salz).

\section{Dolerus aeneus Hartig}

Turkey: Trabzon, Soganli Gecidi, 2,600 m., I ô, 27.v.Ig62 (Guichard \&. Harvey); Trabzon (I7). I + .

Europe and Asia Minor.

\section{Dolerus asper Zaddach}

Dolerus asper megapteroides Muche ㅇ, I964a (nec ô) syn. n.

Turkey, E.: Gumusane (II); Erzurum (7, I2 and I3). I,800 m., 2,390 m., 5 ô, I $+29 . \mathrm{v}$. to I.vi.I962; Bolu (Muche).

ENTOM. 22, 4 . 

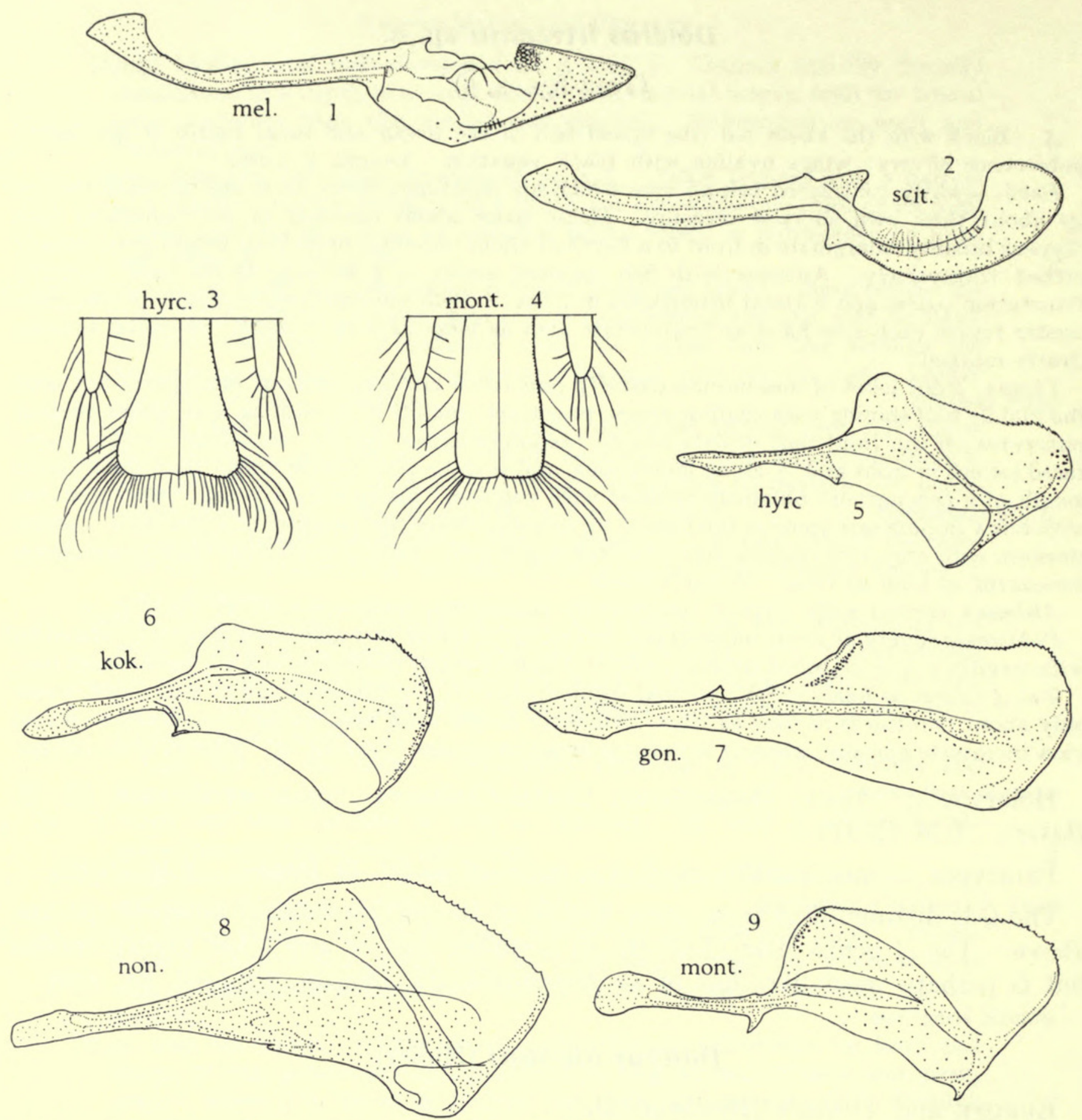

Figs. I-9. I, 2. Penis-valves: I, Avge melanochroa; and 2, A. scita. 3, 4. Sawsheaths from above: 3, Dolerus hyrcanus sp. n.; 4, D. montivagus sp. n. 5-9. Penis-valves: 5. Dolerus hyrcanus sp. n.; 6, D. kokujewi; 7, D. gonager; 8, D. nonutimus; and 9, D. montivagus sp. $\mathrm{n}$.

The specimens from Gumusane and Erzerum have more infuscate wings than any specimens seen from Europe.

Species from Europe, Turkey and temperate Asia to Kamtchatka.

\section{Dolerus haematodes Schrank.}

Turkey, N., N.E. and E.: Samsun (5, I2 and I5); Trabzon (7 and I7); Gumusane (3). Sea level to I,600 m., 80 ô, 53 ‥ 
In the series from sea level at Samsun, I2 out of 23 thave the female colouring, with red pronotum and tegulae; in the series from Gumusane, at I,600 m., only I out of $58 \sigma^{\wedge}$ have this colouring while $57 \hat{0}$, as in typical W. European form, lack any red on pronotum and tegulae.

Europe, Turkey and Transcaucasia.

*Dolerus nonultimus Zhelochovtsev, I94I (with figs.)

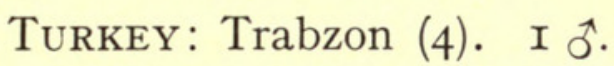

This species belongs to the anthracinus-nitens group with sawsheath as in Benson, I95I-58, fig. I96, but has a distinct penis-valve and saw. The male has infuscate pubescence on the upper head but differs from anthracinus in having the head strongly contracted behind. The female differs from other known females in the group in having infuscate pubescence on its head as in the male, and from anthracinus and coracinus differs also in having unmodified front mesonotal lobes.

TURKEy and Transcaucasia.

\section{$* \dagger$ Dolerus megapterus Cameron}

? Dolerus asper megapteroides Muche, r964a (ô nec of).

Turkey: Gumusane (3). 2 ô. G. Ovacik, 2,000 m., 4 ô, I $9,30 . v .1962$ (Guichard \& Harvey); Erzurum (5). I

Not previously recorded from outside EuRope.

\section{BLENNOCAMPINAE}

\section{ATHALIINI}

Tribe revised by Benson, I962.

\section{$\dagger$ Athalia cuspidata Benson, I954}

ISRAEL, endemic.

\section{$\dagger$ Athalia dimidiata Konow}

TURKEy, endemic.

\section{Athalia bicolor Lepeletier}

Turkey, N.W., W., C., N., N.E., and E.: Edirne (I); Bursa (4 and 9); Usak (I); Bilecik (2); Samsun (5, 6 and I6); Trabzon (3 and 4); Artvin (4); Erzurum (7). 29 ô, 2 ㅇ.

Europe, Mediterranean, Turkey, Transcaucasia to Turkmen Republic. 


\section{$\dagger$ Athalia maculata Mocsáry}

Turkey, N. and C.: Bolu (2); Samsun (30); Amasya (9). 3 ‥

S.E. Europe, Turkey and Transcaucasia.

TURKEY, endemic.

\section{$\dagger$ Athalia paveli Mocsáry}

\section{$\dagger$ Athalia rufoscutellata Mocsáry}

Turkey, W., C., N.E. and E.: Bursa (3, 9); Ankara (II); Corum (2); Samsun (2); Artvin (4); Gumusane (II). 5 ô, 7 ㅇ.

C. and S.E. Europe, Turkey and Transcaucasia.

\section{$\dagger$ Athalia glabricollis glabricollis $\mathrm{C}$. G. Thomson}

Turkey, W., S.W., C., N.E. and E.: Bursa (3); Mugla (7 and 8); Ankara (3, II, I4 and 63); Amasya (I2); Trabzon (9); Erzurum (I); Kars (II). I2 $\widehat{0}$, I5 ㅇ.

All Europe, Mediterranean and Turkey.

\section{$\uparrow$ Athalia glabricollis meridiana Benson, I954}

This subspecies is distinguished from the preceding in having more than half the Costa from the base yellow in the fore wing.

It is known only from IsRAEL and S.W. IRAN (Benson, I962, was wrong in ascribing material from GREECE and TURKEY to this form).

\section{Athalia ahngeri Kokujev}

Turkey, C. and E.: Nigde (5); Gumusane (I5). 2 ㅇ.

Steppe species. Israel, Turkey, Transcaucasia and Mesopotamia to Turkmen, Uzbek Republics and Afghanistan.

\section{Athalia circularis circularis Klug}

Turkey, N.W., W., S., N., C. and N.E.: Istanbul (3 and 9); Mugla (7); Bolu (3); Zonguldak (I); Mersin (7); Sinop (4); Samsun (5, I0, I9 and 2I); Corum (2); Amasya (3 and 5); Tokat (I); Trabzon (I4 and I5); Artvin (6); Rize (6). 21 ô, 2 ‥

Females of the summer flight in the mountains and to a lesser extent those of the autumn flight at sea level have the scutellum and sides of the mesonotal lobes \pm yellow (e.g., from Samsun, Kundaz Ovacik, at I,300 m., 22 . vii. I959 and Samsun, Engiz at sea level, 22.ix.I960). 
Typical form from Europe and Mediterranean; replaced by ssp. melanoptera Benson in E. Siberia, JApan and mountains of C. Asia (Kopet Dag and Afghanistan to the Pamirs, Altai and W. Himalayas).

\section{Athalia cordata Lepeletier}

Turkey, W., S.W., N., N.E. and E.: Kutahya (5); Bursa (3); Aydin (2); Mugla (I and 9); Bolu (3); Samsun (I5); Giresun (7); Trabzon (3, 4 and I4); Rize (3); Kars (I and 9). I5 ô, I5 9 .

Europe, Mediterranean and Turkey.

\section{$\dagger$ Athalia rosae rosae (L.)}

Turkey, N.W., W., S., N., N.E. and E.: Istanbul (3); Kutahya (3 and I0); Mersin (2); Adana (3); Antakya (6); Samsun (5, 6, I9, 20 and 2I); Trabzon (9); Rize (I); Gumusane (4); Kars (I and 7). 8 б, I2 +9.

Europe, Mediterranean, Israel to Iran; S.W. Siberia and N.W. China. Replaced by ssp. ruficornis in E. Asia.

\section{Athalia liberta liberta Klug}

Turkey, N.W., S.W., N., C., N.E. and E.: Istanbul (3); Aydin (I) ; Samsun (Io); Amasya (5 and 7); Trabzon (9 and I4); Gumusane (I3); Erzurum (I0). II 0, 3 ‥

Europe and Mediterranean to S.W. Iran, Mountains of C. Asia to Uzbek, KIRGHIZ and the AmUR region of E. AsIA; replaced by ssp. yanoi in Japan.

\section{$* \dagger$ Athalia cornubiae Benson}

Turkey, N. and N.E.: Bolu (I); Trabzon (7 and I5). Sea level to 2,000 m. 3 ․ Europe and Mediterranean to Iran.

\section{$\dagger$ Athalia paradoxa Konow}

Turkey, W. and E.: Bursa (3); Gumusane (3); Erzurum (3). 3 ㅇ.

Mountains of C. Europe (France, Switzerland and Austria), Macedonia and TURKEY.

\section{EMPRIINI}

*Harpiphorus lepidus (Klug)

Turkey, E.: Erzurum (5). I + , in Quercus scrub.

Not previously recorded outside Europe. 


\section{Monostegia abdominalis (F.)}

Turkey, N., C. and N.E.: Samsun (Io, II and 2I); Ankara (II and 33); Amasya (I and 7); Tokat (I); Trabzon (4). 20 ㅇ.

Europe to Spain and Caucasus, Israel, Turkey, Transcaucasia, Siberia and Atlantic coast of N. America.

\section{*Monsoma pulverata (Retzius)}

Turkey, N.E.: Trabzon (4). I + ; Rize (5). I ô;; Rize (2). I 9.

Not recorded previously outside EUROPE.

\section{Empria archangelskii Dovnar-Zapolskiǐ}

Cyprus, Turkey and Transcaucasia.

\section{Empria pravei Dovnar-Zapolskiř}

N. IRAN: Mazandaran, Chalus-Shahasavar coast of Caspian, I ㅇ, Io.iv. I967 (D. B. Baker).

N. Caucasus, Transcaucasia and N. Iran.

$\dagger$ Empria klugii Stephens

Turkey, N.E.: Trabzon (I7); Rize (2). 3 ㅇ.

Europe, Turkey and Transcaucasia.

\section{$\dagger$ Empria excisa Thomson}

Turkey, N.: Samsun (2). I $\widehat{\jmath}$.

Europe and Turkey.

\section{Empria baltica Conde}

Europe and Transcaucasia.

\section{Empria liturata (Gmelin)}

Turkey, N.E.: Rize (2). I $\widehat{\jmath}$.

Europe, Turkey and Siberia to Irkutsk.

Empria tridens (Konow)

Turkey, N.E.: Giresun (I); Trabzon (3). 2 ㅇ.

EUROPE and TURKEY.

Empria konowi Dovnar-Zapolskiǐ

Ukraine and Transcaucasia. 


\section{Ametastegia equiseti (Fallén)}

Turkey, S., N., C., N.E. and E.: Mersin (7); Samsun (2I); Amasya (9); Trabzon (3); Rize (I and 6); Erzurum (7). 7 ô, 4 ㅇ.

Europe, Mediterranean, Turkey, Siberia to N. America.

\section{Protemphytus pallipes (Spinola)}

Turkey, N. and N.E.: Samsun (6); Trabzon (7). 3 q.

Europe to Iceland, Mediterranean, Turkey to Iran, Siberia, N. America.

$$
\text { Protemphytus carpini (Hartig) }
$$

Europe, Mediterranean, Turkey, Transcaucasia and Siberia.

\section{Protemphytes tener (Fallén)}

Europe, Mediterranean, Turkey, Transcaucasia, Siberia to N. America.

\section{ALLANTINI \\ Taxonus agrorum (Fallén)}

Turkey, N.E.: Artvin, above Artvin, 700 m., I ô, I +, 2.vi.Ig62 (Guichard $\mathcal{E}$ Harvey). Not previously recorded outside Europe.

\section{Taxonus sticticus (Klug)}

C. and S.E. Europe and Transcaucasia.

\section{Allantus togatus Panzer}

Turkey, E.: Erzurum (Io). I ô.

Europe, Turkey, Siberia to Japan.

\section{Allantus viennensis (Schrank)}

C. and S. Europe and Transcaucasia.

\section{Allantus calceatus (Klug)}

Europe and Transcaucasia.

\section{Allantus basalis (Klug)}

Turkey, W. and N.: Bursa (9); Samsun (6). I ô, 2 ㅇ.

N. and C. Europe, Turkey and Siberia. 


\section{Allantus cinctus (L.)}

Turkey, C. and N.E.: Amasya (7 and I3); Gumusane (II). I I 0 , 2 ․

Europe, Turkey, Transcaucasia, Siberia to N. America.

\section{Allantus cingulatus (Scopoli)}

Europe, Transcaucasia and Siberia.

\section{Allantus didymus (Klug)}

Turkey, S., N., C. and E.: Mersin (6); Nigde (5); Bolu (2); Ankara (29); Amasya $(2,3,5,6$ and 7); Tokat (I); Gumusane (I0); Erzurum (4 and 6). I9 ô, I2 ㅇ. N. N. IrAN : Mesanderan, Chalus-Shahsavar coast of Caspian Sea, alt. 20 m., I + , I9.iv. 1966 (D. B. Baker).

Mediterranean, Turkey and Iran.

*Allantus melanarius (Klug)

N. Iran: Mesandaran, Chalus-Shahsavar coast of Caspian Sea, alt. 20 m., 2 , I9.v.Ig66 (D. B. Baker).

All Europe and Iran.

\section{GALIROINI}

\section{Endelomyia aethiops (F.)}

Turkey, N.: Samsun (2 and 25); 2 ㅇ.

Europe, Turkey, Transcaucasia and introduced into N. America.

\section{Caliroa cerasi (L.)}

Turkey, N.: Samsun, Engiz, 9 ô, v.r959 (Guichard).

Holarctic. Obligatorily parthenogenetic races of this species have been introduced with rosaceous fruit-trees, from its native country, presumably in EURASIA, to N. America and almost all other temperate regions of the world. The occurrence of males in Turkey may be significant in indicating the native country of this species, on the theory that introduced parthenogenetic races are descended from normally sexual races, native to some part of the world.

\section{*Caliroa varipes (Klug)}

Turkey, N.W., S., N. and C.: Istanbul (I, 3 and 8); Tekirdag (2); Mersin (6); Kastamonu (I); Samsun (I, 6, 7 and I3); Amasya (I3). I2 $0^{\hat{2}}$, II 9 .

All Europe and Turkey. 
Caliroa annulipes (Klug)

Turkey, N.E.: Trabzon (I5 and I6). 5 ô, 3 ㅇ.

Europe, Turkey and temperate Asia to E. Siberia.

\section{HETERARTHRINI \\ *Heterarthrus vagans (Fallén)}

Turkey, N.E.: Rize, at sea level, 2 ㅇ, I2.iv.I959 (Guichard).

All Europe and Turkey.

\section{FENUSINI}

\section{Metallus beckeri (Konow)}

Very close to European $M$. pumilus Klug, but the hind legs are almost entirely pale (pumilus has hind femur mainly infuscate from base) and the individual marginal saw teeth have more-rounded projections. In the saw therefore it resembles the nearctic $M$. rohweri MacGillivray; $M$. albipes Cameron and $M$. gei Brischke have saws resembling $M$. pumilus. The $\delta$ antenna is flattened as in pumilus.

Turkey, N. and N.E.: Samsun (9). I ô, 2 क; Trabzon, at sea level, I + , 24. viii. I 959 (Guichard); Rize (5); I +.

Only known from Turkey.

\section{Profenusa thomsoni (Konow)}

Europe, Transcaucasia and N. America (? introduced).

\section{Profenusa pygmaea (Klug)}

Turkey, W. and C.: Bilecik (I); Amasya (I3). I ô, I 9 .

Europe and Turkey.

Hinatara recta (C. G. Thomson)

Europe and Transcaucasia.

\section{Scolioneura hyrcana sp. $\mathrm{n}$.}

o. Black except for the following, which are brownish to yellowish white: labrum, palps, antennal segments 9 and underside of 5 to 8, tarsi, tibiae and apical one-third to one-half of femora. Wings hyaline; stigma, and venation black to piceous. Length $4.5 \mathrm{~mm}$.

Head with mouthparts normal, antenna about $\times \mathrm{I} \cdot 5$ breadth of head; 4 th segment $=8$ th $+9^{\text {th }}=$ ist $\times 0.8$. Eyes much enlarged and strongly converging in front where the distance between them is much less than the longest measure of the eye $(\mathrm{I} \cdot \mathrm{O}: \mathrm{I} \cdot 5)$. Malar space linear.

Thorax with tarsal pulvilli of legs developed only on two apical tarsomeres. Claws bent medially at right angles and with sharp basal tooth.

Wings normal. 
Abdomen without any visible sculpture.

Pubescence dense on upper head and mesopleura; on mesopleura up to about as long as diameter of an ocellus but on head shorter than this. On mesonotum and abdomen sparse.

Holotype ô. N. Iran: Mazandaran, Shalus-Shahsavar coast, I8.iv.Ig66 (D. B. Baker). B.M. (N.H.).

This species is distinguished at once from S. betuleti Klug and S. tirolensis Enslin by its strongly converging eyes, which are much closer together in front than their greatest length (in S. betuleti and tirolensis they are further apart than their greatest length, as $\mathrm{I} \cdot 2: \mathrm{I} \cdot 0$ ) and also by the loss of the tarsal pulvilli on the two basal tarsomeres of the legs.

\section{Messa hortulana (Klug)}

EUROPE and Transcaucasia.

\section{Fenusa dohrni (Tischbein)}

Turkey, E.: Rize (I). I

Europe, temperate Asia and N. America; introduced to S. Africa.

\section{Kaliofenusa ulmi laevinota ssp. n.}

Differs from the typical north holarctic race in that the coriaceous surface sculpture on the front and lateral mesonotal lobes is absent and the lobes are entirely smooth. The frontal basin is much shallower and the furrow separating the frontal area from the inner orbits is more clearly defined.

Holotype 9. Turkey: Mugla, Ula (Mezarlik) 700 m., on Ulmus, I7.iv.I962 (Guichard \& Harvey). B.M. (N.H.).

Paratypes. Turkey: Mugla, Ula (Mezarlik) $700 \mathrm{~m}$.; on Ulmus, I $q$ and $8 \hat{\jmath}$, I7.iv. I962 (Guichard \& Harvey); Bursa, Bursa-Mudanya Rd., 50 m., I + , 28 .iv. I962 (Guichard \& Harvey); Corum, Iskilip, 700 m., I ㅇ, 9.v.I962 (Guichard \& Harvey).

Species holarctic in distribution.

\section{LYGAOTINI}

This tribe was revised by Benson, I966.

\section{*†Seljukia tenebrosa Benson, I966}

Turkey, S.: Mersin, Gözne 600 m., 6 今ૈ, Ir ㅇ, 3-5.vi. I96o (Guichard \& Harvey).

The representatives of this species were taken in a rocky broken terrain with alder-lined streams, $34 \mathrm{kms}$ north of Mersin.

\section{PHYMATOGERINI}

\section{Phymatocera aterrima (Klug)}

C. and S. Europe and Transcaucasia. 


\section{TOMOSTETHINI}

Tomostethus nigritus claripennis Enslin

N. Africa and Turkey.

Typical subspecies throughout Europe and across Siberia.

Eutomostethus gagathinus (Klug)

E. gagathinus meridionalis Benson, I954, syn. $\mathbf{n}$.

Turkey, E.: Erzurum (I3). I 9 .

All Europe, N. Africa, Cyprus, Turkey, Transcaucasia and Siberia.

\section{Eutomostethus luteiventris (Klug)}

All Europe, Transcaucasia and N. America.

\section{Eutomostethus ephippium vopiscus (Konow)}

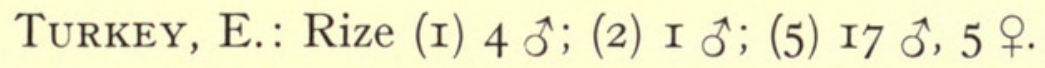

This subspecies differs from the typical one in that males predominate and that whereas the $\delta^{t}$ has an entirely black body (as in one of the two $q$ phases of the typical subspecies) the $q$ is more extensively red than in the red phase of the typical subspecies: it has the whole thorax red (in the red phase of the typical subspecies the mesoscutellum, with its post-tergite and the mesosternum are black). The legs of o vopiscus differ from those of both of forms of the typical subspecies in having the apical third of the femora, all the tibiae except the extreme apex as well as the basal tarsal segment and \pm the apical one yellowish white; in the males the pale colour is brownish.

The typical subspecies is now found throughout EURope and N. AmERICA (? introduced) and there is a black-bodied form in the Himalayas: ssp. vopiscus is recorded only from Turkey and Transcaucasia.

Stethomostus fuliginosis (Schrank)

Turkey, C. and N.E.: Bolu (3); Ankara (4); and Rize (I). $4 \hat{\delta}$, I.+

Europe, Turkey, Siberia, to Japan and N. America.

Stethomostus funereus (Klug)

Turkey, N.E.: Rize (I). 3 ô.

Europe, Turkey and Siberia.

\section{BLENNOGAMPINI \\ Monophadnus spinolae (Klug)}

Turkey, N.W.: Edirne (I). I .

EURope and TURKEY. 


\section{Monophadnus fulviventris athalioides Jakovlev stat. $\mathbf{n}$.}

The only known difference between $M$. athalioides $q$ and fulviventris Scop. $q$ is in the colour of the thorax; the underthorax is all black in fulviventris, and in athalioides with the upper mesopleuron red. The mesonotum, apart from the postergite of the scutellum, is all red in fulviventris but is \pm black-flecked in athalioides. They are probably best treated as geographical subspecies. $M$. $f$. fulviventris is restricted to C. and S. Europe and M. f. athalioides to Transcaucasia and China.

\section{Monophadnus longicornis Hartig}

Turkey, N.: Samsun (I2, I4 and I5). 5 ô, 5 ㅇ.

EURope and TURKEy.

\section{Monophadnus pallescens (Gmelin)}

Turkey, N.E.: Trabzon (4 and I7); Rize ( 2 and 5). II 9.

Temperate Eurasia and N. America.

\section{PERICLISTA Konow}

Apericlista Enslin

Cornaria Malaise 1964, syn. n.

\section{Key to European Males and Females}

I Abdomen mainly pale beneath. Hind wing with anal cell sessile or subsessile (peduncle not more than one-half as long as width of anal cell). Clypeus medially emarginate. Ovipositor not longer than hind tibia . . .

- Either abdomen mainly dark beneath or anal cell in hind wing with peduncle longer than one-half width of anal cell, or clypeus subtruncate, or ovipositor longer than hind tibia

2 (I) $\delta$ with abdomen mainly yellowish above and hind wing with marginal vein; o w with head black above and hind wing often with enclosed middle cell .

$\widehat{ } \widehat{t}$ with body entirely black above except for white tegula and apical margins of tergites, and hind wing without marginal vein; ㅇ with head mainly reddish yellow above and without enclosed middle cell in hind wing. MediterRanean (Morocco, and Portugal to Balkans)

andrei (Konow)

3 (2) Antenna about as long as head + thorax; 우 with mesonotum mainly red. C. Europe to Spain and Caucasus

Antenna longer than head + thorax; $ᄋ$ mesonotum all black. ( $\hat{0}$ not seen). C. EUROPE

4 (I) Anal cell of hind wing with peduncle longer than one-half of width of cell. Hind wing with or without enclosed middle cell in o or marginal vein in $\widehat{0}$. Ovipositor longer than hind tibia

Anal cell of hind wing subsessile (peduncle less than one-half of width of cell). Hind wing with enclosed middle cell in 9 and marginal vein in $\sigma^{\star}$. Ovipositor shorter than hind tibia. Legs with femora black. Spain and Portugal

dusmeti (Konow)

5 (4) Clypeus emarginate medially. ㅇ hind wing with enclosed middle cell, and $\delta$ with marginal vein. Malar space at least two-thirds as long as diameter of ocellus in $\sigma^{\wedge}$ and $q$ 
- Clypeus evenly truncate. $q$ hind wing without enclosed middle cell and $\widehat{\sigma}$ without marginal vein. Malar space less than one-half of diameter of ocellus in $q$ and linear in $\hat{\sigma}$. Body entirely black except for white-margined pronotum and abdominal segments. C. EUROPE . . albipennis (Zaddach)

6 (5) Head and thorax with only normal pubescence on middle of mesonotum, not longer than diameter of ocellus

Head and thorax clothed in woolly pubescence on mesonotum up to $\times 2$ diameter of ocellus. Abdomen black with pale apical margins to segments and, in ㅇ, with orange lateral band on down-turned lateral portions of tergites. Legs in $\sigma^{t}$ yellowish with black coxae and bases of femora, but in o femora mainly yellow with only extreme bases infuscate.

C. Europe

pubescens (Zaddach)

7 (6) Legs in both $\delta$ and $q$ mainly yellow except only for coxae and extreme bases of femora. Abdomen in $\sigma^{t}$ infuscate below but \pm yellow above; + mainly black with pale apical margins to segments. Austria and TURKey lenta Konow Legs in both $\delta$ and +9 with mainly black femora and \pm pale tibiae. Abdomen in both $\delta$ and $q$ mainly black with pale apical margins to segments. C. EUROPE

- lineolata (Klug)

\section{Periclista lenta Konow}

Turkey: Mugla, Kestep, 50 m., 3 ठิ, I2.iv. I962 (Guichard \& Harvey).

Turkey [type locality Brussa].

Monardis plana (Klug)

Europe and Transcaucasia.

Ardis brunniventris (Hartig)

Europe, Turkey, Siberia to Japan and N. America.

\section{Cladardis elongatula (Klug)}

EUROPE and TURKEy.

\section{Claremontia tenuicornis (Klug) Ross, I95I}

Blennocampa tenuicornis (Klug) Konow.

Pseudoblennocampa tenuicornis (Klug) Malaise, I935.

Monophadnoides tenuicornis (Klug) Benson, I952.

It seems to me reasonable to separate Claremontia Rohwer, I909, in which the hind-orbits have a deep coriaceous groove and the hind wing has no enclosed middle cells, from Monophadnoides, in which the deep coriaceous hind-orbital groove is absent and the hind wings have normally an enclosed middle cell $M$. To Claremontia also belong alternipes Klug, comb. n. puncticeps Konow, comb. n. confusa Konow, comb. n. and the following species.

Europe, Turkey and Siberia. 


\section{Claremontia waldheimii (Gimmerthal) comb. $\mathrm{n}$.}

EUROPE and SiBERIA.

\section{*Monophadnoides ruficruris (Brullé)}

Turkey, N.E.: Rize (5). I 0 .

Males of this species in Britain have some of the middle tergites \pm marked with yellow. The $\widehat{\sigma}$ from Turkey has tergites $3-5$ and \pm 2 and 6 , and sternites $2-6$ yellow. This may indicate a distinct race but more specimens would be needed to demonstrate this.

Not previously recorded outside EUROPE.

\section{Halidamia affinis (Fallén)}

Turkey: Amasya (5). I ㅇ.

Europe, Turkey, Transcaucasia and N. America.

\section{Pareophora pumilio Konow}

N. IRAN: Mazandaran, Chalus-Shahasavar coast of Caspian, I + , 28.iii. Ig66 (D. B. Baker).

S. and S.W. Caspian coast. [Type locality Azerbaydzhan, S.S.R., Lenkoran].

\section{TENTHREDINIDINAE ERIOGAMPINI \\ *Eriocampa ovata ovata (L.)}

Turkey, E.: Tokat (I). 3 ㅇ.

Europe, not previously recorded from Turkey, introduced into N. America.

\section{*Eriocampa ovata nitens ssp. $\mathbf{n}$.}

A series of this species from E. TURKEY lacks the transverse sculpture on the abdomen.

Holotype +. Turkey : Rize, Cayeli, I5 m., 22.viii.I959 (Guichard). B.M. (N.H.).

Paratypes. Turkey: Rize, Cayeli, I5 m., I9 ㅇ, 22.viii.I959 (Guichard); Rize, Rize, I5 m., I + , 2I.viii.I959; Trabzon, Trabzon, at sea level, I $ᄋ$, 24.viii.I959 (Guichard). B.M. (N.H.).

The absence of transverse sculpture on the abdomen occurs as a rare aberration in the typical race of this species (e.g. SwEden: Skanne, Kivik, I + , I5.vii. 938 (D. M.S. E J.F. Perkins)), and is also characteristic of certain other species in the genus such as E. dorpatica Konow (E. EUROPE) and E. peineae Zirngiebl (IRAN)it is possible that the latter is another form of $E$. ovata. 
IRAN.

$$
\text { Eriocampa peineae Zirngiebl, I956 }
$$

\section{*Eriocampa umbratica (Klug)}

Turkey, N.E.: Trabzon (3, 4 and I6); Rize (2, 3 and 5); Artvin (4). 38 ô, 5I , Not previously recorded from outside EUROPE.

\section{PERINEURINI}

\section{Aglaostigma langei (Konow)}

\section{Europe and Transcaucasia.}

\section{*Aglaostigma aucupariae lacteore ssp. n.}

o differs from typical race in that the inter-antennal area and the whole face below the antennal sockets (except for the anterior tentorial pits) are yellowish white and this colour is continued along the edge of the inner orbits. (In the typical race most of the clypeus, the inter-antennal area, and the face below the antenna are black.)

The o is scarcely distinguishable from that of the typical race except that the costa of the fore wing is paler apically.

Holotype ô. Turkey: Trabzon, Zigana Gecidi, I,650 m., 22.v.Ig62 (Guichard \& Harvey). B.M. (N.H.).

Paratypes. Turkey: Bursa, Uludag, 500 m., I ô, I + , 26.iv. I962 (Guichard \& Harvey); Samsun, Samsun, I + , 20.vii.I959 (Guichard); Trabzon, Zigana Gecidi, I,650 m., I o, 22.v.I962; Artvin, above Artvin, I,800 m., I q, 6.vi.rg62 (Guichard \& Harvey). B.M. (N.H.).

Typical race throughout Europe to E. Siberia.

\section{TENTHREDOPSIS A. Costa}

\section{Key to SPECIES-GRoups OF THE WORLD}

I Clypeus subtruncate in front

Clypeus acutely or semicircularly excised in front medially to a depth of more than one-fourth of its maximal length. Penis valve without a spine. (Textfigs. io and i9). Europe and E. Mediterranean . . stigma-group (p. I57)

2 (I) Postocellar region slightly convex medially where it is about level with upper edge of the occipital carina and the temples. Antennal crests much smaller than ist antennal segment, and joined behind to the edge of the frontal area without any deep excision

Postocellar region excavated so that medially it is much below the level of the sharp edge of the occipital carina and the temples. Antennal crests often larger than ist antennal segment and separated from edge of frontal area by a deep excision. Penis valve as in stigma-group. N. Eurasia

3 (2) Antenna not white-ringed, nor abdomen with ist tergite black and flecked with opaque white, nor mesopleuron dull with dense sculpture 

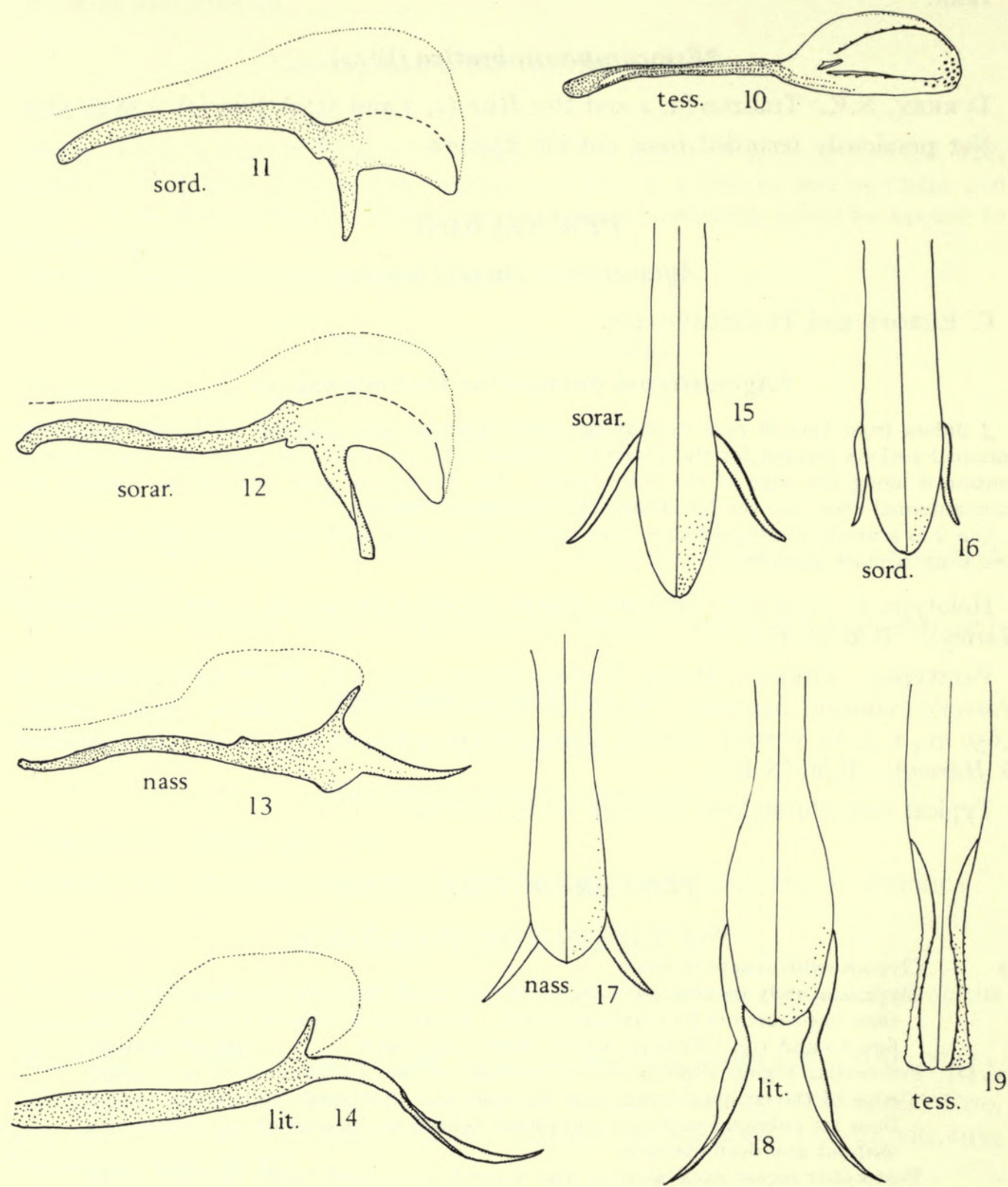

Figs. IO-I9. IO-I4. Tenthredopsis penis-valves in lateral view: Io, tesselata; II, sordida; I2, soraria; I3, nassata; and I4, litterata. I5-19. Tenthredopsis penis-valves in dorsal view: 15, soraria; I6, sordida; I7, nassata; 18, litterata; and 19, tesselata. 
- Either antenna white-ringed, or abdomen with ist tergite black and flecked with opaque white, or mesopleuron dull with dense sculpture . . .

4 (3) Antenna longer than costa and stigma of fore wing. Clypeus not entirely black. Abdomen never with flecks of opaque white, but in 9 usually with a pair of ventral lateral black stripes. Penis valve as in stigma-group. C. EuRope and C. to E. Asia

tarsata-group (p. I 59)

Antenna not as long as costa + stigma of fore wing. Clypeus often entirely black. Abdomen sometimes with flecks of opaque white. Penis valve as in stigma-group. S.E. Europe and E. Mediterranean. albonotata-group (p. I 59)

5. (3) ô with apical tergite carinate medially between two glabrous depressions; penis valve with spine (Text-figs. II-I 8). O either has hypopygium with the posterior medial projection enlarged and strongly excised apically (Text-figs. 2I-23), or has malar space \pm equal to inter-antennal line (I: I to $\mathrm{I} \cdot 2)$ and c. $\times \mathrm{I}_{5} 5$ diameter of front ocellus. Occipital carina well developed and continuous. + abdomen variously coloured but not with a pair of black ventral lateral stripes on a paler background except sometimes in sordida. PAlaearctic . . . . . . . nassata-group (p. i6 I)

- $\quad$ o with apical tergite not modified thus; penis valve as in stigma-group, without a spine. o with medial posterior projection of hypopygium not enlarged nor excised apically. Malar space much shorter than inter-antennal line ( $\mathrm{I}: \mathrm{I} \cdot 3$ to $\mathrm{I} \cdot 5)$ and at most as long as front ocellus, or occipital carina obsolescent laterally behind the orbits. \& abdomen usually with a pair of black ventral lateral stripes. E. Mediterranean . . . festiva-group (p. i6o)

\section{Key to $A U R I C U L A T A$-group Males and Females}

Antenna longer than costa + stigma of fore wing. $q$ black with following parts white: labrum, clypeus, face, antennal crests, orbits, \pm temples, pronotum, tegula, scutellum, flecks on mesonotal lobes and pleura, broad ventral and lateral strips on abdomen which dorsally is brown, medially, legs; legs brown to piceous with coxae, trochanters and tarsi \pm white; $\hat{\sigma}$ differs in that the underside of the thorax is \pm entirely white, and the head is almost entirely white except for frontal area. 9-10 mm.

The Japanese race, ssp. japonica Takeuchi, is often larger (IO-I $2 \mathrm{~mm}$.) and the black is more extensive: the $q$ is entirely black except for the white labrum, clypeus, lateral and ventral stripe of the abdomen, and the legs are black except for the yellowish white trochanters, front and middle tibiae, and tarsi. N. Palaearctic (N. Europe to E. Siberia and Japan)

carinata Malaise

Antenna shorter than costa \pm stigma of fore wing. $q$ mostly yellowish brown with white markings; ô mostly black above and \pm white below. 9-Io $\mathrm{mm}$. N. Palaearctic (N. Europe to E. Siberia) . † †auriculata C. G. Thomson 1

\section{Key to STIGMA-group Males and Females} each side of labrum, inner orbits, temples, pronotum, tegula, scutellum and

1 The following are synonyms of $T$. auriculata: Tenthredo sachalinensis Matsumura, I9II, syn. n. Tenthredopsis camtschatcali Enslin, I927, syn. n. 
metanotum. Wings sybhyaline; venation black except for base of stigma, $C$ and $S c$ of fore wing, which are white. 9-II mm. S. and S. E. Europe

2 (I) Head with occipital carina well developed from gena to vertex

floricola Costa

Head with occipital carina obsolescent laterally behind eyes.

Head and thorax black with white on labrum, inner orbits, temples, pronotum, tegula, scutellum; abdomen fulvous except for ist tergite and sawsheath. Wings subhyaline and venation black except for base of stigma, $C$ and $S c$ of fore wing. 9-II mm. TuRkey . . . . . . .

guichardi sp. n.

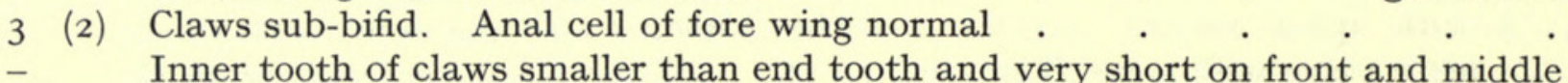
legs. Anal cell of fore wing with cross-vein missing (? abnormal specimen). Black species with the following parts white: labrum, sides of clypeus, inner orbits, temples, edge of pronotum, tegulae, femora (except for inner stripe) and tibiae (except for inner stripe of hind pair) and yellowish white lateral stripe from 2 nd to 7 th tergites of abdomen. $8 \mathrm{~mm}$. Turkey. O only

harveyi sp. n.

4 (3) Antenna shorter than costa of fore wing in $q$ and about as long as costa in $\hat{\delta}$. With 8 th segment $\times 2-2.5$ times as long as broad. with venation yellowish white to brown. Black with the following parts yellow: labrum, sides of clypeus, fleck on inner orbits, fleck on temple, underside of antenna, edge of pronotum, tegula, scutellum, tergites 3-6 of abdomen (except for mid-dorsal stripe) and most of legs. $\hat{\sigma}$ as $q$ except that the middle segments of the abdomen are buff with a black mid-dorsal band and a ventral lateral band each side. 9-I I mm. C. and N. Europe stigma (Fallén)

Antenna as long as costa in $q$ and costa + stigma in $\delta$, with 8 th segment $\times 2.5-3$ times as long as broad. Wings subhyaline or slightly infuscate, with venation mainly black or brown. 6.5-I I $\mathrm{mm}$.

This complex of colour-forms more or less segregated into local races but with every intergradation have heretofore been treated as divisible into numerous species. Basically the of colour pattern is black with the following parts white: labrum, \pm clypeus, fleck on inner orbits and temples, underside of antenna, edge of pronotum, tegula and middle of scutellum. Abdominal segments 3-6 are reddish yellow apart from a \pm developed mid-dorsal line and a longitudinal lateral ventral stripe each side. The femora, tibiae and tarsi are also mainly reddish yellow.

In the paler forms the extent of white increases and the head can be almost entirely white apart from the frontal area, the posterior orbits, the postgenae and occiput; on the thorax the pronotum can become entirely white and white flecks can develop on the mesonotal lobes and mesopleura; on the abdomen yellowish white and then white flecks appear first on the sides of the first tergite and then yellow progressively entirely replaces the reddish yellow colour of the abdomen (f. albata Konow, Caucasus). In some forms the basic reddish brown is replaced by white and the black mid-dorsal line extends along the apical margins of the tergite (f. hungarica Klug and lactiflua Klug, C. and S.E. Europe). In f. corcyrensis André S. and S.E. Europe, the basic pattern is altered by the labrum, clypeus, scutellum and \pm legs becoming entirely black, with, at the same time, the disappearance of the mid-dorsal and lateral ventral abdominal lines. The basic 0 pattern is as that described above for stigma. Europe and E. Mediterranean

tesselata (Klug) ${ }^{2}$

${ }^{2}$ Synonyms of T. tessalata: Tenthredo hungarica Klug, syn. n. T. lactiflua Klug, syn. n. Perineura excisa Thomson, syn. n. Tenthredopsis corcyrensis André, syn. n. T. albata Konow, syn. n. 


\section{Key to $A L B O N O T A T A$-group Males and Females}

Lateral ridge to frontal area of head continuous with antennal crests. Antenna
not white-ringed and scutellum not marked with white. Two colour phases
described originally as subspecies: mainly brown and mainly black. Burma-

\section{Key to TARS $A T A$-group Males and Females}

Smaller $(8-9 \mathrm{~mm}$.) with head strongly contracted behind eyes in dorsal view. Mesopleura scarcely punctate but with fine surface sculpture. S.E. Asia (BURMa and Formosa) .

Larger (Io-I $2 \mathrm{~mm}$.) with head parallel-sided in dorsal view. Mesopleura dull with dense surface sculpture between coarse punctures. (Black with 4 middle abdominal segments red in 9 , and scutellum white-marked; 0 with the middle abdominal segments \pm infuscate as in scutellum.) C. and S.E. Europe

ํํำ tarsata (Konow) YUNNAN frontier

birmanica (Malaise) $^{5}$

${ }^{3}$ Synonyms of $T$. albopunctata: Tenthredo benthini Rudow, syn. n. Tenthredo balcana Mocsáry, syn. n. Tenthredopsis casia Konow, syn. n. T. quadrannulata Konow, syn. n. T. triforis Konow, syn. n.

${ }^{4}$ Synonyms of T. annuligera: Tenthredo tischbeini Frivaldskii, syn. n. *Tenthredopsis andrei Konow, syn. n. ${ }^{*} T$. pisinna Konow, syn. n.

$\mathbf{5}$ Synonym of $T$. birmanica: Thomsonia birmanica nigrorufa Malaise, syn. $\mathbf{n}$. 
Lateral ridge to frontal area of head and antennal crests notched medially. Antenna often \pm white-ringed from 6 th and following segments, and scutellum usually white-marked. S.E. Asia (Burma and Formosa)

insularis Takeuchi ${ }^{6}$

\section{Key to FESTIVA-group Males and Females}

In the B.M. (N.H.) there is a 9 unnamed N. American species of this group of Tenthredopsis. It was sent to the Museum by Norton in $\mathrm{I} 865$ as a representative of his recently described Allantus piceocinctus but it is not even congeneric with the type of that species. It was collected at Farrington, Connecticut. The genus is not now recognized in N. America, though larvae are recorded by Maxwell, I955 : 93.

I Green species with black markings, and either occipital carina obsolescent laterally, or inner tooth of claw diverging from end tooth and slimmer than it

- Brown or red and black species. Occipital carina well-developed along whole hind margin of head, and inner tooth of claw parallel to end tooth and equal to it in girth

2 (I) Occipital carina obsolescent behind eyes. Malar space (ㅇ) $\times 2$ diameter of front ocellus. Claws with inner tooth parallel to end tooth and equal to it in girth. Pulvillus on hind basitarsus only about half as long as apical breadth of basitarsus. Green with black fleck on frontal and postocellar regions of head, on each of the mesonotal lobes and in the middle of each tergite so as to form a medial abdominal row. Stigma entirely green. $8.5 \mathrm{~mm}$. TransCAUCASIA

viridis Zhelochovtsev

Occipital carina well developed along whole hind margin of head. Malar space (ㅇ) about $\times \mathrm{I}_{5} 5$ diameter of front ocellus. Claws with inner tooth diverging from end tooth and slimmer (ㅇ) or shorter ( $\left.\sigma^{\prime}\right)$ than it. Pulvillus on hind basitarsus about as long as apical breadth of hind basitarsus. Green with black markings on head, mesonotum, mesosternum, middle dorsal line and two lateral ventral lines on abdomen. Stigma dark with green base. 9-ro mm. Transcaucasia

ornatrix Konow

3 (I) Anal cell of fore wing with cross-vein suberect and nearer base than apex of cell. Claws sub-bifid. Abdomen banded yellow or red, and with a pair of ventral dark stripes

Anal cell of fore wing with cross-vein oblique and near middle of cell. Claws with inner tooth shorter than end tooth. Black with white markings on head, thorax and margins of abdominal segments.

Unique ㅇ. $7 \mathrm{~mm}$. (? abnormal dwarf) has asymmetric supernumerary cross-veins. Transcaucasia . . . . . . . nigrescens Konow

4 (3) Head with clypeus, inner orbits, temporal spot and thorax with edge of pronotum and fleck on mesonotum white. Inner hind tibial spur about half as long as basitarsus

Head with clypeus black and thorax (apart from tegula and \pm mesoscutellum) entirely black. Inner hind tibial spur only about two-fifths as long as basitarsus.

Abdomen with yellow band covering segments 3-9. Legs yellow with infuscate coxae and hind tarsus. $\hat{o}$ not seen. $7.5 \mathrm{~mm}$. Transcaucasia and TURKEY

nigella Konow

${ }^{6}$ Various colour forms of this species were originally described as sympatric subspecies on the BurmaYunnan frontier and together with another from Formosa are synonyms of insularis Takeuchi: Thomsonia insularis brunnescens Malaise, syn. n. T. insularis continentalis Malaise, syn. $\mathbf{n}$. T. insularis deannulata Malaise, syn. n. T. insularis fuscicornis Malaise, syn. n. T. insularis ruficornis Malaise, syn. n. (Formosa). 
5 (4) Abdomen with segments 2-6 pale yellow. Hind coxae entirely black. $\widehat{o}$ not seen. 8-IO mm. TURKeY . . . . . . . straminata Konow Abdomen with segments 2-8 reddish yellow. Hind coxae black with broad lateral and ventral yellowish white stripes. Io mm. Transcaucasia

festiva Konow

KEY TO NASSATA-GROUP

I

우우

ธิరే

Spine on penis-valve shorter than inner hind tibial spur (Text-figs. II-I3 and I 5-I7). Hypopygium with at most a small emargination, not as wide as the length of this spur (Text-figs. 20, 22 and 23). Colour variable but antennae are always fuscous above and pale brown below .

Spine on penis-valve longer than inner hind tibial spur (Text-figs. I4 and I8).

Hypopygium with a wide apical emargination about as wide as the length of this spur (Text-fig. 2I). Head white below and on orbits, black above; antennae reddish yellow below and brown above; thorax yellowish white with black and yellow markings above; abdomen mainly reddish yellow marked with black on basal tergites. Large species IO-I $2 \mathrm{~mm}$. EUROPE

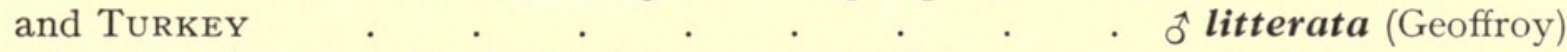

(2) Penis-valve with spine attached before apex (Text-figs. I I, I2, I5 and I6).

Penis-valve with spine at apex (Text-figs. I3 and I7).

ô without external vein to hind wing is thought by some to represent the $\hat{\sigma}$ of another species known as coquebertii but their exact significance is unknown. 7-II mm. Europe, Turkey and Siberia to Japan ot nassata (L.)

4 (3) Spines set close together on penis-valve and much shorter than apical breadth of hind tibia (Text-figs. II and I6). Straw-coloured species with black markings on head, thorax and abdomen. 8-Io mm. EUROpE ot sordida (K1.)

Spines set about half their own length apart on penis-valve and about as long as apical breadth of hind tibia (Text-figs. I 2 and I5). Black species with yellowish white markings on face, orbits and thorax. II mm. TransCAUCASIA

5 (I) Medial projection to hypopygium greatly enlarged so it is longer and broader at base than length of an inner middle tibial spur (Text-figs. 2 I and 22) .

Medial projection to hypopygium much shorter and narrower than length of inner middle tibial spur .

6 (5) Projection to hypopygium narrowed behind, where it is narrower than the length of an inner middle hind tibial spur, and at its apex it is sharply excised (Text-fig. 2I). Malar space almost equal to inter-antennal line and diameter of front ocellus. Pulvillus on basitarsus about as long as basal breadth of basitarsus and almost as long as pulvillus on succeeding tarsomere. II $-\mathrm{I} 3$ mm.

Projection to hypopygium scarcely narrowed behind where it is as wide as the length of an inner middle hind tibial spur, and at its apex it is broadly and slightly emarginate (Text-fig. 22). Malar space only about two-thirds of inter-antennal line and equal to diameter of front ocellus. Pulvillus on hind basitarsus about two-thirds of basal breadth of basitarsus and two-thirds of length of pulvillus on succeeding tarsomere. $\mathrm{I} 2 \mathrm{~mm}$.

q sororia Konow

7 (5) Straw-coloured species marked with brown and black. Projection to hypopygium deeply excised apically (Text-fig. 23). 9-I I mm.

ㅇ sordida (Klug)

Very variable in colour from yellowish white, to brown, or red and more or less marked with black and white, to almost entirely black. Projection to hypopygium at most emarginate at an extreme apex (Text-fig. 20). 9-12 mm.

우 nassata (L.) 

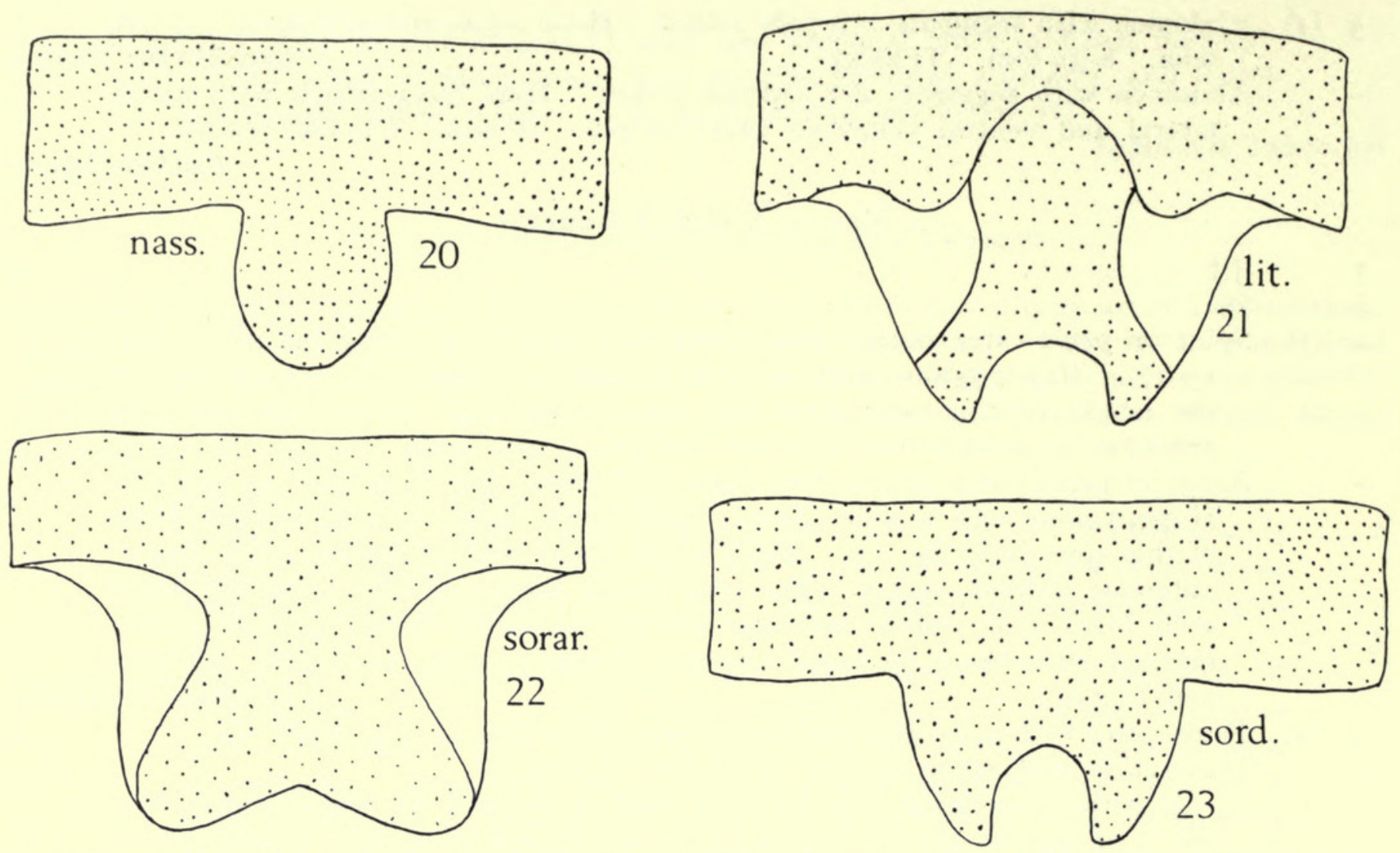

FIGS. 20-23. Tenthredopsis hypopygia: 20, nassata; 21, litterata; 22, soraria; and 23, sordida.

\section{[Tenthredopsis floricola A. Costa}

TURKEY: Istanbul (2-3). 2 ․

S. and S.E. EUROPE].

\section{*Tenthredopsis guichardi sp. $\mathrm{n}$.}

․ Head and thorax black with the following parts creamy white: labrum, \pm clypeus, inner orbits, fleck behind eyes on lateral hind margin of head above, underside of flagellum, hind margin of pronotum, tegula, scutellum and fleck in middle of its post-tergite, metascutellum, small fleck on front and middle coxae and large fleck on side of hind coxa. Legs yellow except for most of coxae, trochanters and extreme base of front and middle and most of hind femora, which are black. Wings subhyaline; stigma with basal half white and apical black; costa and subcosta yellow; rest of venation piceous except at extreme base of wing. Abdomen yellowish brown, except for the mainly black Ist, \pm middle of 2 nd and 9 th tergites, and sawsheath. Length: Io-I I mm.

Head shining, with obsolescent punctation. Clypeus medially emarginate in front to depth of nearly one-third of its total length. Malar space nearly as long as diameter of front ocellus. Antenna about $\times 2$ as long as width of head behind the eyes. Frontal area with raised lateral margins fused with antennal crests and with a deep median groove from the front ocellus to the interantennal region. Carina on hind margin of head obsolete laterally behind the eyes so that genal carina below is separated from the occipital carina above. Distance between hind ocelli less than distance of an ocellus from occipital carina as $I \cdot 0: I \cdot 7$, and less than distance of an ocellus to margin of eye as $\mathrm{r} \cdot 0$ : $\mathbf{r} \cdot 9$.

Thorax normal with underthorax and mesonotum, apart from front half of front lobes, almost impunctate except in the sunken lateral areas of the latter which are rugose and the 
scutellum which is opaque with a line of regular punctures separating the post-tergite which is \pm alutaceous.

Legs normal; inner hind tibial spur about half as long as basitarsus.

Wings normal.

Abdomen with fine surface alutaceous sculpture above. Hypopygium and saw as in $T$. stigma.

Pubescence over head and thorax pale and shorter than diameter of ocellus.

$\widehat{o}$ as in $q$ but thorax including tegular entirely black and white on inner orbits and temples is much reduced. Pubescence on head infuscate. Distance between hind ocelli less than distance between ocellus and occipital carina as $\mathrm{I} \cdot \mathrm{O}: \mathrm{I} \cdot 3$, and as distance between ocellus and eye margin as $\mathrm{I} \cdot \mathrm{O}: \mathrm{I} \cdot 7$. Hind wings with marginal vein. Genitalia much as in $T$. stigma Klug (Text-figs. Io and I9).

Length: 9-10.5 $\mathrm{mm}$.

Holotype ㅇ. Turkey: Ankara, Kubuk, 830 m., 22.v. I960 (Guichard \& Harvey). B.M. (N.H.).

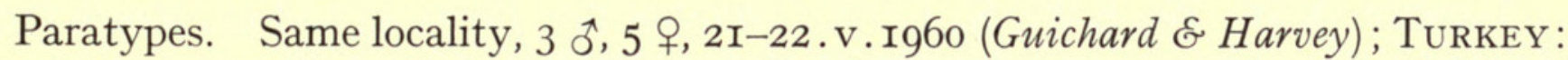
Erzurum, 20 m. from Ispir on Ikizdere Road, I,700 m., I , 2.vi. I962 (Guichard \& Harvey). B.M. (N.H.).

\section{*Tenthredopsis harveyi sp. n.}

․ Black with the following parts white to yellowish white: palps, mandible bases, labrum, clypeus (except middle third), underside of antenna, spot on gena, inner orbits and spot behind temple, edge of pronotum, tegula, legs (except coxae, trochanters, spot on inner base of front femur, line on inner side of middle femur, and inner side of hind femur and tibia, most of hind tarsus), lateral each side of abdomen covering one-fourth of the width of tergites $2-7$, a lateral fleck each side of middle of ist tergite and \pm narrow apical margins of succeeding tergites and sternites.

Wings hyaline with costa and subcosta and base of stigma white, rest of venation piceous. Length $8.5 \mathrm{~mm}$.

Head shining, with obsolescent punctation. Clypeus medially emarginate in front to depth of nearly one-third of its total length. Malar space slightly longer than diameter of front ocellus. Antenna more than $\times 2$ as long as width of head behind eyes. Frontal area slightly convex above but with a deep round concavity above the interantennal area. Occipital carina clearly defined throughout. Hind ocelli further apart than from occipital carina as $\mathrm{I} \cdot \mathrm{O}: \mathrm{I}^{\cdot} 4$ and from margin of eye as $\mathrm{I} \cdot \mathrm{O}: \mathrm{I} \cdot 9$.

Thorax shining but with definite punctures dense on front of mesonotum, sparse on lateral lobes, scutellum, episternum and sternum of thorax, but the depressed lateral areas of the mesonotum as well as the mesepimeron and metapleura are dull and regulose. Legs normal with inner spur of hind tibia about half as long as basitarsus, but the inner tooth of the claw is not as long as the end tooth on the hind legs and on the front and middle legs is only about half as long as end tooth.

Wings with the cross-vein to the anal cell missing in the fore wings but this may be an individual abnormality.

Abdomen finely alutaceous above, hypopygium and saw normal (as in T. stigma).

Pubescence pale on head and thorax and up to as long as diameter of an ocellus.

Holotype +. Turkey: Bolu, Ala Dagi, 2,000 m., Kartal Kaya Tepe, I5.vii. 1962 (Guichard \& Harvey). B.M. (N.H.). 


\section{Tenthredopsis tesselata (Klug)}

Turkey, N.W., W., N. to E.: Widespread from Istanbul (3); Bursa (4); Samsun (5 and 6); Erzurum (6). Up to I,700 m. 52 ๙, 59 ㅇ, iv-vi, in many colour forms including f. albata, Konow, f. excisa Thomson and f. corcyrensis André.

N. Iran: Elburz Mts., 2,000 m. (G. Heinrich).

All Europe and Turkey to N. IRAN.

$\dagger$ Tenthredopsis convergens Benson, I954

ISRAEL.

\section{Tenthredopsis albopunctata (Tischbein)}

Turkey, N.W., W., S.W., S., C., N.: Istanbul (2); Bursa (4 and 9); Mugla (ro); Antalya (I0); Samsun (24); Amasya (2, 5, 6, 7 and I3); Corum (2); up to I,000 m. (near Merzifon in Amasya on 3.vi.59), 17.iv to 6.vi.1959-62 and 20.vii.59 (near sea level at Samsun? 2nd brood). Forms with and without white-ringed antennae or tarsi occurred together. $20 \hat{\delta}, 2$ ㅇ.

S.E. Europe (Yugoslavia, Bulgaria, Greece and Turkey) and Asia Minor.

\section{Tenthredopsis annuligera (Tischbein)}

Turkey, C.: Amasya (I and 6). I $\hat{o}, 6$ q.

C., S. and S.E. Europe (France, Germany, Czechoslovakia, Yugoslavia, Corfu, Russia) and Turkey.

\section{Tenthredopsis albonata (Brullé)}

S.E. Europe (Greece and Turkey) and E. Mediterranean (Syria, Lebanon and Israel).

Tenthredopsis viridis Zhelochovtsev, I94I

Transcaucasia.

\section{$\dagger$ Tenthredopsis ornatrix Konow}

Transcaucasia.

\section{$\dagger$ Tenthredopsis nigrescens Konow}

Turkey (W.): Usak, Bulgaz Dag, Namrun, I,400-I,600 m., I ㅇ, 9-I6.vi.1965 (Gembloux Coll. Belgium), and Transcaucasia.

\section{$\dagger$ Tenthredopsis nigella Konow}

Transcaucasia, Turkey, 


\section{$\dagger$ Tenthredopsis straminata Konow}

S. Turkey (Taurus Mountains).

\section{$\dagger$ Tenthredopsis festiva Konow}

Transcaucasia.

\section{Tenthredopsis litterata (Geoffroy)}

Turkey, N.W., C. and E.: Istanbul (3); Amasya (3 and 7) and Erzurum (6). $4 \hat{0}, 2$ ‥

All Europe and Turkey.

\section{$\dagger$ Tenthredopsis sororia Konow}

Transcaucasia.

\section{Tenthredopsis nassata (L.)}

Turkey (C. and N.E.): Ankara (39); Cankiri, Isik Dag, I,200 m., I q, 25 . vi. Ig66 (Demelt Coll.); Amasya (3, I3); Trabzon (I5).

Europe, Asia Minor, Siberia to Japan.

\section{TENTHREDINIDINI \\ RHOGOGASTER Konow}

Rhogogaster was revised by Benson, I965.

$* \dagger$ Rhogogaster genistae Benson

Turkey, C.: Amasya (7). I $\widehat{0}, 2$ ㅇ․

Also Europe, N. Africa.

\section{Rhogogaster picta (Klug)}

Turkey, N.W., W., C., N.E. and E.: Istanbul (3); Bilecik (I and 2); Konya (3); Amasya (7 and I3); Giresun (3); Erzurum (4). Io ठิ, I4 +.

Also Europe and Turkey.

$$
* \dagger \text { Rhogogaster dryas (Benson) }
$$

Turkey, C.: Amasya (5 and I8). 4 ㅇ.

EUROPE and TURKEY. 


\section{Rhogogaster punctulata (Klug)}

Turkey, N.E.: Trabzon (4 and I5); Artvin (4). I,246-I,800 m. 5 ㅇ․

These specimens seem to be racially distinct from the normal European form in the complete lack of the lateral row of black spots each side of the abdomen. This form has also occurred as a rare aberration in Finland.

Europe and Turkey.

\section{$* \dagger$ Rhogogaster naias Benson, I965}

Turkey, E.: Gumusane (5). II $\widehat{\delta}$, I2 우.

Type series.

\section{Rhogogaster viridis (L.)}

Turkey, C., N.E. and E.: Ankara (I2); Amasya (I3); Trabzon (3); Rize (8); Artvin (3) ; Erzurum (Io). From sea level up to 2,600 m., 3 ô, 7 ㅇ. Holarctic species.

\section{$* \dagger$ Rhogogaster chlorosoma (Benson)}

Turkey, N.W., C., N.E. and E.: Istanbul (9); Ankara (I5, 35 and 4I); Tokat (I); Konya (3); Giresun (3); Erzurum (6). From sea level up to I,400 m., I ô, 23 o.

Europe, Turkey and Siberia.

\section{Rhogogaster auctor Weiffenbach, I967}

Turkey: Nigde, Ciftehan, vi. I965 and Ankara, Kizilkahaman, v. I965 (Demelt Coll.).

\section{TENTHREDO L.}

Keys to the palaearctic species of the bifasciata-, zonula-, scrophulariae- and arcuata-groups, (as well as the species now segregated as Elinora and Cuneala) were given by Enslin, I9Io, and to the olivacea-mesomelas-, cyanatra-atra- and maculata-temula-groups by Enslin, I920.

\section{Key to SPECIES-GROUPS}

I

Antennal crests, over antennal sockets, reach further forward (in dorsal view) than the level of the front of the eyes, and in the olivacea-mesomelas group, the crests are separated from the sides of the frontal area by a deep excision; the area between the crests is more than half as deep as the distance between them. Flagellum of antenna more than $\times \mathrm{I}_{2} \frac{1}{2}$ the width of the head behind the eyes

- Antennal crests confluent with the sides of frontal area, and not reaching
forward further than the level of the front of the eyes and/or the area between

- Antennal crests confluent with the sides of frontal area, and not reaching
forward further than the level of the front of the eyes and/or the area between them is not half as deep as the width between them

2 (I) Mostly green or green and black species but some partly yellow or brown, with antennal crests separated behind from the sides of the frontal area by a deep excision

olivacea-mesomelas-group (p. I67) 
Species variously coloured, often with black, red, brown or yellow but some with green, antennal crests behind confluent with sides of frontal area

cyanata-atra-group (p. I67)

3 (I) Head strongly swollen behind eyes and, together with thorax, entirely black (except at most for small yellow flecks on edge of pronotum). Wings infuscate on at least apex of front pair (W. PAlaearctic) bifasciata-group (p. I69)

Head not strongly swollen behind eyes, or head and thorax more richly marked with yellow. Wings \pm hyaline or with infuscate patches .

4 (3) Head with temples shining and at most sparsely punctured, and occipital carina obsolete behind post-ocellar region. Antenna less than twice as long as breadth of head behind eyes. Male hind tarsal claws without acute basal lobe

zonula-group (p. I7o)

Head dull with strong punctation above or occipital carina well developed along whole of hind margin of head or including the post-ocellar region. Antenna long or short. Male hind tarsal claw with or without acute basal lobe

5 (4) Wings hyaline in fresh specimens and antenna short (penultimate segment less than $\times \mathrm{I}_{2} \frac{1}{2}$ as long as broad). Stigma mostly pale. Claws usually with a basal lobe \pm developed. (Holarctic) . . . $\quad$ arcuata-group (p. I76)

Wings strongly flavescent, or infuscate, at least partly. Antenna often elongate (penultimate segment at least $\times \mathrm{I}_{\frac{1}{2}}$ as long as broad). Stigma often dark. Claws often without basal lobe . . . . . . .

6 (5) Fore wings evenly \pm infuscate. Stigma black. Abdomen with metallic lustre. Mesosternum each side and mesoscutellum with tooth-like projection. Antenna often with penultimate segment less than $\times \mathrm{I}_{\frac{1}{2}}$ as long as broad. (Oriental) .

opposita-group

Fore wings subhyaline, flavescent or with infuscate patches. Stigma often pale. Abdomen not metallic. Mesosternum and often mesoscutellum without tooth-like projection. Antenna with penultimate segment at least $\times \mathrm{I}_{2} \frac{1}{2}$ as long as broad

7 (6) Wings flavescent, or fore wing with infuscate apex or front margin. Stigma

pale. (HOLARCTIC) . . . vespiformis-scrophulariae-group (p. I75)

Wings hyaline or stigma dark. (PALAEARCTIC) maculata-temula-group (p. I73) finschi and japonica

The OLIVACEA-MESOMELAS-group

Tenthredo mesomelas $\mathrm{L}$.

Turkey, N., N.E. and E.: Bolu (I); Zonguldak (I); Trabzon (3, 4, I5 and I6); Gumusane (7 and 8). 700-2,600 m. I3 ô, 28 ․

Europe, Turkey, Transcaucasia and Siberia.

The $C Y A N A T A$-ATRA-group

\section{Tenthredo atra duplicata (Enslin)}

This race differs from the typical race in always having white on the genae and each side of the Ist tergite.

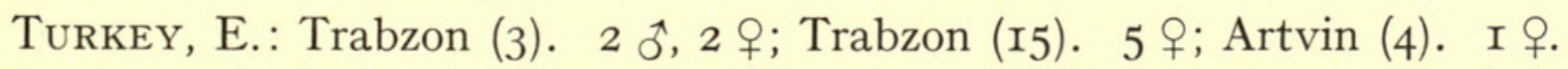

Europe and Transcaucasia.

The species occurs throughout Europe to E. Siberia. 


\section{Tenthredo mandibularis $\mathrm{F}$.}

C. Europe and Transcaucasia.

\section{Tenthredo araxana Mocsáry}

Transcaucasia.

\section{Tenthredo caligator Eversmann}

Turkey, N.E.: Trabzon (I5-I6). 40 oิ, 59 ㅇ․

Turkey and Transcaucasia.

\section{Tenthredo albopicta Puls}

Turkey, N.E.: Trabzon (I5-I6). I 0 .

TURKey and Transcaucasia.

\section{Tenthredo discophora Konow}

Turkey, N., N.E. and E.: Bolu (I); Gumusane (7 and II); Trabzon (I4, I5, I6 and I7); Rize (8). I,400 to 2,500 m. 22 ô, 5I +, 27. V-I4.vii.

Turkey and Transcaucasia.

Tenthredo purpurea Puls

Turkey, N.E.: Trabzon (I5-I6). 3 ô, 4 우.

Turkey and Transcaucasia.

Tenthredo livida L.

Turkey, N.: Zonguldak (I). I + .

Europe, Turkey, Transcaucasia and Siberia.

\section{Tenthredo colon Klug}

Turkey, W. and N.E.: Kutahya (9); Trabzon (I4 and I5). 3 бิ, 3 ㅇ.

Europe, Turkey, Transcaucasia and N. Asia to Kamtchatka.

\section{Tenthredo balteata Klug}

Turkey, N.E.: Trabzon (I5); Rize (8). 2 ㅇ. Not previously recorded outside EUROPE.

\section{Tenthredo solitaria Scopoli}

C. and S. Europe and Transcaucasia. 


\title{
Tenthredo ferruginea Schrank
}

\author{
Turkey, N.E.: Trabzon (I5); Rize (8). I ô, I 9. \\ Europe, Turkey, Transcaucasia, Siberia to Japan.
}

\section{Tenthredo luteipennis Eversmann}

\author{
Turkey: Trabzon (I3). I ô; (I4, I5). I7 ô, 26 ㅇ. \\ Turkey, and Caucasus and Pamirs up to $3,400 \mathrm{~m}$.
}

\section{The BIFASCIATA-group}

This group consists of those species with \pm infuscate wings, and head, greatly swollen behind the eyes, together with the thorax entirely black (except at most for small lateral yellow fleck on pronotum). Abdomen black with sometimes one or more tergites flecked or banded with yellow but very variable in colour pattern as are the wings.

\section{Key to Males and Females}

I Mesoscutellum shining, almost impunctate . . . . . . . . . . 2

- Mesoscutellum at least partly dull with dense punctures or surface sculpture . 3

2 (I) Pubescence on head and thorax silvery, not infuscate. II-I3 mm. of not seen. S.E. Europe and E. Mediterranean . . . . kiefferi (Konow)

Pubescence on head and mesonotum infuscate. II-I3 mm. C. and S. EUROPE,
E. Mediterranean to Iran
costata Klug

3 (I) Mesoscutellum entirely dull with dense surface sculpture between punctures. Pubescence on head and mesonotum fuscous
Mesoscutellum with some shining areas anteriorly between the punctures . 5 - Abdomen with 3 rd to 7 th tergites (o) or 3 rd and 4 th $\left(0^{*}\right)$ margined apically with yellow and legs with yellow tibiae and tarsomeres, flecked with brown at their apices. Inner hind tibia scarcely half as long as basitarsus. Wings
of 9 flavous + infuscate apically. I $2-14 \mathrm{~mm}$. C. EUROPEAN ALPS at their apices. Inner hind tibia scarcely half as long as basitarsus. Wings
of $q$ flavous \pm infuscate apically. I $2-14 \mathrm{~mm}$. C. EuropeAn Alps yellow flecks on 2 nd and 4 th, but $\sigma^{t}$ often entirely black. Legs entirely black. Inner hind tibial spur more than half length of basitarsus. Wings usually

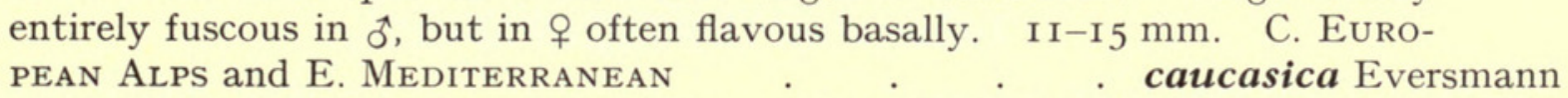
stecki (Konow)

5 (3) Abdomen or legs \pm marked with yellow. Inner hind tibial spur longer than apical width of tibia. Wings sometimes \pm flavous . . . . .

Entirely black species with strongly infuscate wings. Inner hind tibial spur about as long as apical width of tibia. I3-I4 mm. E. Mediterranean

6 (5) Abdomen with ist tergite black. Scutellum strongly convex, gibbous . . 7

- $\quad$ Abdomen with Ist, 3rd, 4th and sometimes 2nd, 5th and 6th tergites flecked or margined apically with yellow, as also is often the pronotum; otherwise black, except for paler tibiae and tarsi. Mesoscutellum only slightly convex in middle. I2-I $5 \mathrm{~mm}$. ôt not seen. TURKESTAN . . . bractea Enslin

7 (6) Fore wings fuscous throughout and either stigma dark brown or pubscence on head and thorax partly fuscous 
Fore wings flavous basally with infuscate apices and yellow stigma. Pubescence on head and thorax silvery. IO-I $2 \mathrm{~mm}$. EUROPE and SIBERIA rossii (Panzer)

8 (7) Stigma and costa of fore wing yellow or brown. I2-I4 mm. C. and S. Europe

bifasciata Müller

Sigma and costa of fore wing infuscate. (? subspecies of preceding). I I-I $3 \mathrm{~mm}$. ô not seen. E. Mediterranean . . . . . . diversipes Mocsáry

\section{Tenthredo kiefferi (Konow)}

Turkey, S.W., S. and C.: Aydin (2); Antalya (5 and I4); Mersin (7, I2 and I4); Ankara (I2, I4, I5, 2I, 35 and 37); Corum (2); Amasya (2, 3 and 7); Kayseri (3 and 4); Sivas (3). Up to r,600 m. in Mersin. 69 ô, 93 ㅇ.

S.E. Europe, Lebanon, Israel and Turkey.

\section{Tenthredo costata Klug}

Turkey, C., N.E. and E.: Nigde (5); Ankara (15); Amasya (7); Sivas (3); Giresun (3); Artvin (2); Erzurum (4 and 6). 700-I,700 m., 2 0, II ․

C. and S. Europe, Turkey and Iran.

\section{Tenthredo caucasica Eversmann}

Turkey, N.E. and E.: Trabzon (3, I4, I5 and I6); Gumusane (Io); Erzurum (6). I,400-2,000 m., 33 o, 60 ․

European Alps (France and Switzerland), Turkey and Transcaucasia.

\section{Tenthredo violascens (Konow)}

Turkey, E.: Erzurum (6). I3 ㅇ.

Also Transcaucasia.

\section{Tenthredo diversipes Mocsáry}

Syria, LEBANON and IsRaEL.

\section{The ZONULA-group}

\section{Key to Males and Females}

I Flagellum of antenna mainly black. Head scarcely swollen behind eyes or \pm punctate above. Wings subhyaline; stigma infuscate apically

Flagellum of antenna mainly yellow. Head strongly swollen behind eyes and impunctate above. Wings yellowish throughout; stigma yellow with brown apex.

Occipital carina continues only up to level with top of eyes, being obsolete behind temples. S.E. Europe and E. Mediterranean

flavipennis Brullé

2 (I) Tongue long (prelabium longer than greatest measure of eye). Occipital carina obsolete behind upper half of eyes, temples and postocellar region. Frontal area densely punctate. Clypeus excised to only about one-third of its total length. Abdomen with Ist tergite black, but with whole of $4^{\text {th }}$ and 5 th segments yellow above and often 3 rd and 6th laterally 
- Tongue normal (prelabium shorter than greatest measure of eye). Occipital carina defined along whole hind margin of head except behind postocellar region. Frontal area sometimes shining with sparse punctures. Clypeus excised to more than one-half its total length. Abdomen with \pm Ist, whole of $5^{\text {th }}$, sometimes $4^{\text {th }}$ and apices of some of the following tergites yellow .

3 (2) Frontal area deeply concave in the middle to a depth and size much greater than that of an inverted ocellus. Antenna with ist segment yellow. S.E. Europe and E. Mediterranean . . . . . . dialeuca (Konow)

- Frontal area not concave in the middle to a depth as great as an inverted ocellus. Antenna entirely black. C. and S. Europe and E. Mediterranean

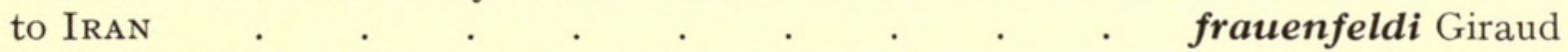

4 (2) Mesopleura above dull with dense surface sculpture . . . . . . $\quad$. 5

- $\quad$ Mesopleura above shining between the follicles of dense pubescence . $\quad$. 6

5 (4) Ist antennal segment and tegula mainly yellow. Frons densely punctured and lower inner orbits dull with dense surface sculpture. C. and S. EURopE and N. Africa . $\quad . \quad$. $\quad . \quad$. $\quad . \quad$. distinguenda (R. v. Stein) Ist antennal segment entirely, and tegula mainly, black. Frons sparsely punctured and lower inner orbits shining between surface sculpture. E.

Mediterranean . . . . . . . . hyrcana sp. n. (p. I72)

6 (4) Hind femur tipped with black at apex only. Antenna with one or two basal segments mostly yellow. Hind tibia and tarsus of $q$ marked with black or dark brown. C. and S. Europe, N. Africa and E. Mediterranean zonula Klug

Hind femur with most of inner side black. Antenna entirely black. Hind tibia and tarsus of $q$ marked with reddish brown. EUROPE amoena Gravenhurst

\section{Tenthredo flavipennis Brullé}

Allantus lautus Konow.

A. luminosus Konow, syn. n.

Turkey, E.: Gumusane (II); Erzurum (6). I,700-I,800 m.

S.E. Europe, Turkey and Transcaucasia.

\section{Tenthredo dialeuca Konow}

Allantus jugalis Konow, syn. n.

Turkey, N. and E. : Samsun (8); Gumusane (I0); Erzurum (I5). Up to 2,300 m., I $\widehat{\jmath}, 4$ 우.

S.E. Europe, Turkey and Transcaucasia.

\section{Tenthredo frauenfeldi Giraud}

Allantus helveticus Konow, syn. n.

A. merceti Konow, syn. n.

A. montanus Enslin, I9ro.

Turkey, N. and E.: Samsun (5); Gumusane (I0). Up to I,800 m., I ô, 2 ㅇ. Iran: Mazandaran, Kalar Dasht, Sardab, Rud Valley, $3 \mathrm{~km}$. above Rudbarak, I,500 m., I +, I7.iv.I966 (D. B. Baker).

C. and S.E. Europe, Turkey and Iran. 


\section{Tenthredo zonula Klug}

Allantus similis Mocsáry.

A. nazareensis André, syn. n.

A. serena Konow, syn. n.

Turkey, N.W., W., S.W., S., C., N.E. and E.: Istanbul (3); Bursa (2 and I4); Aydin (2); Mugla (9 and ro); Antalya (9 and ro); Nigde (5); Ankara (I2); Corum (2); Amasya (2, 3 and 7); Artvin (2); Erzincan (I); Erzurum (5, 6 and I4). Up to $2,250 \mathrm{~m}$. in the east, 50 ô, 35 ㅇ․

C. and S. Europe, Israel, Syria, Lebanon and Turkey.

\section{*Tenthredo hyrcana sp. $\mathbf{n}$.}

(Text-figs. 26, 26a)

․ Black with the following parts yellow: mandibles, labrum, clypeus, hind margin of pronotum, outer margin of tegula, trochanters extreme base, and apex of femora, tibiae except apices of middle and hind pair and apices of middle and hind tarsomere, apical half of ist tergite, $5^{\text {th }}$ abdominal segment and apex of 7 th, 8th and 9 th tergites. Wings subhyaline; base of stigma and costa yellow, apex of stigma and rest of venation piceous. Length 8-9 mm.

Head slightly contracted behind and with clearly marked occipital carina, though this is obsolete behind postocellar region; labrum acute in front; clypeus deeply excised in front to depth of more than half total length of clypeus, slightly convex above; flagellum of antenna longer than width of head behind $(\operatorname{as~} \mathrm{r} \cdot 3: \mathrm{r} \cdot \mathrm{O})$. Frontal area with an 8 -shaped medial concavity. Punctation sparse and very fine on ridges of frontal area and lower inner orbits but gena dull with dense surface sculpture.

Thorax normal and shining between fine widely-separated punctures on mesonotum. Mesothorax below dull with very dense surface sculpture. Legs normal; inner hind tibial spur scarcely half as long as basitarsus. Abdomen dull above with dense transverse alutaceous sculpture. Saw. (Text-figs. 26 and 26a.)

Pubescence white and well-developed on head and thorax and in length up to about $\times \mathrm{I}_{2}$ diameter of an ocellus.

$\widehat{o}$ as $q$ but that the legs are much paler (the whole of the front legs are yellow except for the spurs, the claw bearing segment and extreme bases of other segments; the middle legs except for the tarsus and an outer black line on the tibia and the hind legs except for the base of the coxae, the apical half of the femur together with the whole tibia and tarsus which are black), the costa is darker, the ist tergite is pale only on the apical margin and \pm the 3 rd $-5^{\text {th }}$ sternites of the abdomen.

Holotype ㅇ. Transcaucasia: Armenia, Delizhan, I,500-2,200 m., I6.vi.I934 (A. N. Zhelochovtsev). B.M. (N.H.).

Paratypes. Transcaucasia: I ô (same data). Turkey: Ankara, Idris Dagi, I,300 m., I +, 30.vi. I962 (Guichard \& Harvey); Amasya, 500 m., I2 ô, 22-23.v. I959 (Guichard), 460 m., 2 ô, I ㅇ, 2-6.vi. I959; Erzurum, Ispir, $20 \mathrm{kms}$ on Ikisdere Rd., 700 m., I ô, 2.vi.I962 (Guichard \& Harvey). B.M. (N.H.).

This species is differentiated in the key above from $T$. distinguenda Stein, to which it is most closely related. According to Dr. Zhelochovtsev this species was recognized and named "Allantus hyrcanus" by Gussakovskin in his MSS on the Tenthredininae in the Faune de l'URSS before the war, but was never published. I have therefore 

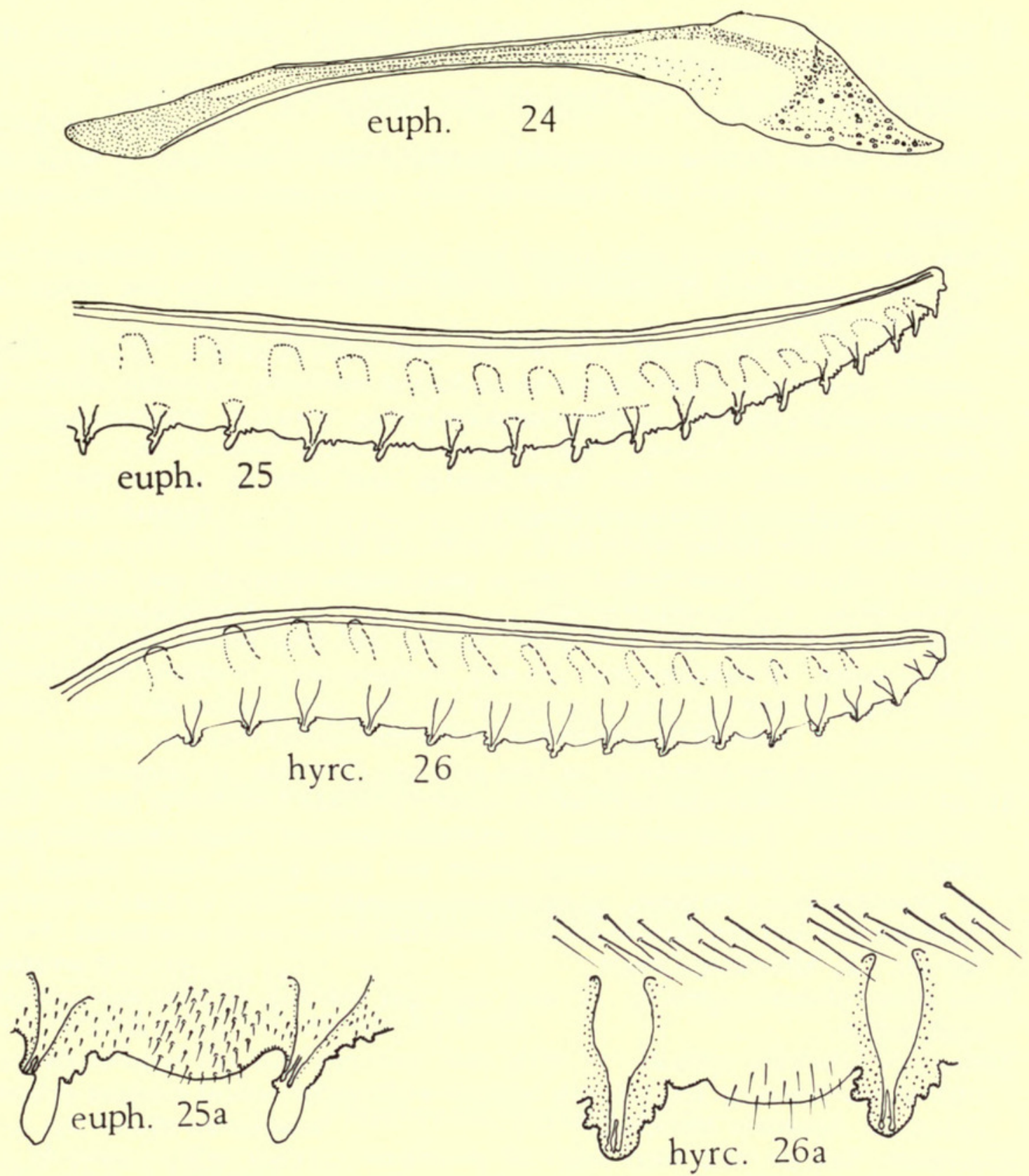

Figs. 24-26. 24. Tenthredo euphorbiae sp. n. penis-valve. 25-26. Tenthredo saws: 25 , euphorbiae sp. n.; and 26, hyrcana sp. n. 25a-26a. Enlarged Ioth and IIth teeth from apex of saws: 25a, euphorbiae sp. n.; 26a, hyrcana sp. n.

selected as the holotype the specimen sent to me by Zhelochovtsev, bearing the name given by Gussakovskii.

\section{The MACULATA-TEMULA-groups}

Key to Males and Females

I

\& Abdomen only one tergite (3rd) or two (3rd and 4 th) entirely yellow; 5 th tergite at least partly black; ô with underthorax pale. Mesopleura with angular projection. Hind claws with acute basal lobe. Io-I $2 \mathrm{~mm}$.

(temula sspp.) 
ㅇ Abdomen with two tergites (4th and 5 th) entirely yellow or orange; 3rd tergite at least mainly black; $\delta^{x}$ with underthorax black. Mesopleura without angular projection. Hind claws without basal lobe. I2-I6 $\mathrm{mm}$.

2 (I) $\sigma^{*}$ has 8 th tergite with at most apical margin yellow; 우 has apex of abdomen with at most 8 th and 9th tergites broadly yellow and a small fleck in the middle of the 7 th .

$\delta$ has 8 th tergite with at least apical half yellow and $q$ apex of abdomen has at least a large fleck of yellow on the 7 th tergite and mostly has yellow on 6 th-9th tergites.

Scutellum sharply raised so as to form right angle in profile. 0 3rd tergite entirely yellow and $+4^{\text {th }}$ tergite black-flecked medially, scutellum all black.

Britain, S.W. France, N. Spain and Italy

temula celtica Benson

3 (2) ot 3 rd tergite entirely yellow; + 4 th tergite with medial fleck of black. Scutellum flatter, with front face more shining and with no yellow fleck. C. Europe (excluding Spain and Italy)

temula temula Scopoli

of 3 rd tergite with medial black fleck; + with $4^{\text {th }}$ as well as 3 rd tergite entirely yellow. Scutellum forming almost a right angle in profile and often with yellow fleck. E. Mediterranean . . . . . temula xanthaspia Enslin

4 (I) Middle and hind coxae and trochanters mainly, and hind femur entirely, black in both sexes. +9 abdomen with 4 th and $5^{\text {th }}$ segments pale yellow; $\sigma^{t}$ abdomen pale yellow except for the \pm infuscate ist and 2nd tergites and two apical segments. 0 tarsus strongly swollen so that in ventral view the 2 nd and 3 rd tarsomeres are less than twice as long as broad (Text-fig. 29) (maculata sspp.)

Middle and hind coxae and trochanters mainly pale and hind femur pale at base in both sexes. O abdomen with $4^{\text {th }}$ and $5^{\text {th }}$ segments orange above and pale yellow below; $\delta$ abdomen orange above and pale yellow below except for \pm infuscate first 2 tergites. $\delta$ tarsus less strongly swollen so that in ventral view the 2nd and 3 rd tarsomeres are more than twice as long as broad (Textfig. 30). E. Mediterranean vestita André

5 (4) Hind tibia infuscate apically. \& with 2 nd and 6 th-8th tergites not marked with yellow. .

Tibiae not infuscate apically. 9 with $2 \mathrm{nd}, 3 \mathrm{rd}$, 6th and 7 th tergites flecked with yellow laterally and 6th-9th tergites with medial apical margins yellow. Italy, N. Appenine Mountains

maculata diana ssp. n. (p. I74)

6) (5) Scutellum, tengula and hind edge of pronotum marked with yellow in o. W. and C. Europe and ItAly (except N. Appenines) maculata maculata Geoffroy Thorax entirely black except for narrow outer edge of tegula. Hungarian Plain (Czechoslovakia, Hungary and Austria) maculata semseyi Mocsáry

\section{[Tenthredo maculata diana ssp. $\mathrm{n}$.}

ㅇ. Black with the following parts yellow: labrum, clypeus, posterior half of pronotum, tegula, scutellum, fleck on metapleura and on fore and middle coxae, trochanters and front of fore and middle femora, all tibiae and tarsi, 4 th and 5 th segments of abdomen together with a lateral fleck each side of 2nd, 3rd and 6th tergites and medial hind margin of 6th-9th tergites.

Wings subhyaline, with costa, front of subcosta and veins in anal regions, yellow; stigma and rest of venation black.

Structure as in $T$. maculata but mesoscutellum is more convex medially. $\mathrm{I}^{-\mathrm{I}} 4 \mathrm{~mm}$. long.

Holotype ㅇ. Italy: Emilia, Mt. Bretra, I.v. Igr2 (A. Fiori) (Genova Mus.).

Paratypes. Italy, Emilia, La Lama, I ㅇ, ıo.vi. I962 (A. Servadei) (Padova Mus.); Marches, Mt. Catria, I ㅇ, v.r933 (Alzona). B.M. (N.H.)]. 
Tenthredo vestita André

Turkey, C., N., N.E., E.: Amasya (3, 6 and I3); Samsun (I7); Gumusane (I4); Trabzon (3, 4 and I5); Erzurum (6). 500-I,400 m., 23 ô, 24 ㅇ.

Turkey and Transcaucasia.

\section{Tenthredo temula xanthaspis Enslin}

Turkey, N. and N.E.: Sinop (2); Trabzon (3 and 4); Rize (5); Artvin (3). 900I,400 m., 3 oิ, 7 우.

Subspecies only in Turkey and Transcaucasia. Species otherwise confined to EUROPE.

\section{The VESPIFORMIS-SCROPHULARIAE-group}

These species are coarsely punctured on the head, which is often swollen behind the eyes; the antennae often have the flagellum yellow and the wings often have infuscate patches.

\section{Tenthredo marginella Fabricius}

Turkey, W., N.E. and E.: Bursa (I3); Trabzon (I4); Gumusane (4). I $\hat{0}, 3$ ‥ Europe, Turkey and Transcaucasia.

\section{*Tenthredo zona Klug}

Turkey, S.W.: Mugla (Io). I 9 .

Not previously recorded outside EUROPE.

\section{Tenthredo vespa Retzius}

Turkey, N.E.: Trabzon (I5). I ㅇ.

Europe, Turkey, Transcaucasia and Siberia.

\section{Tenthredo scrophulariae L.}

Turkey, C.: Tokat (I); Sivas (2). 3 ô, 2 ㅇ․

Europe, Turkey and Transcaucasia.

\section{Tenthredo excellens (Konow)}

$\dagger$ Allantus persa Konow.

Turkey, S., C. and E.: Mersin (I2 and I5); Ankara (9, I2, 3I, 37 and 39); Amasya (I and 7); Kayseri (3); Sivas (3); Erzurum (7, 8 and 9). 5,000-2,300 m., 21 ô, 24 9.

N. Iran: Elburz Mountains, Ig66 (D. B. Baker).

S.E. Europe, Turkey, Transcaucasia and Iran. 


\section{Tenthredo cinctipleuris (Enslin)}

Turkey, S. and E.: Mersin (7); Gumusane (5); Erzurum (6). I4 0 , I2 9.

Iran: Elburz Mountains, N. side of Kandara Pass, 2,360 m., I ô, I ㅇ, 9.vi. I965 (D. B. Baker).

Europe, Turkey, Transcaucasia and Iran.

\section{*Tenthredo propinqua Klug}

Turkey, N.: Kastamonu-Cankiri Border (2). 2,000 m., I ô.

S.E. Europe and Turkey.

\section{Tenthredo luteocincta Eversmann}

Turkey, N.E.: Trabzon (I4 and I5). 3 ㅇ.

Turkey, Transcaucasia and S.E. Russia.

\section{Tenthredo reitteri (Enslin)}

Allantus lituratus Mocsáry.

Turkey, W., C., N.E. and E.: Kutahya (9); Cankiri (4); Trabzon (4, I4, I5 and I6); Gumusane (7). I,400-2,500 m., 42 ô, 23 ㅇ.

Turkey and Transcaucasia.

\section{Tenthredo lauta (Konow)}

TRANSCAUCASIA.

\section{Tenthredo luminosa (Konow)}

TURKEY.

$$
\text { The ARCUATA-group }
$$

The species of this group were revised by Benson (I959).

\section{Tenthredo schaefferi Klug}

Outside C. and S.E. Europe, a few specimens of f. perkinsi of this species were found in N. Iran: Elburz Mountains, 2,500-3,200 m. (see Benson, I959).

\section{$* \dagger$ Tenthredo acerrima Benson}

Turkey, N.E. and E.: Trabzon (I4 and I5); Artvin (4); Gumusane (8). I,400$2,450 \mathrm{~m}$., vi-viii, many $\delta^{t}$ and o.

Europe and Turkey. 


\title{
$* \dagger$ Tenthredo titania Benson
}

Turkey: Trabzon, Zigana Dagi, I,400 m., plentiful vii-viii, I959-60, and Soganli Gecidi, 2,600 m., 40 ô, 84 ㅇ, v-vii. I960-62 (Guichard \& Harvey).

Transcaucasia and Turkey.

\section{Tenthredo trivittata (André)}

$\dagger$ Allantus kussariensis Konow, syn. n.

TRANSCAUCASIa.

\section{*Tenthredo euphorbiae sp. n.}

\author{
(Text-figs. 24, 25, 25a)
}

․ Green with the following parts black: head above the clypeus (except for gena and lower outer orbits), with antenna (except underside of flagellum), prothorax (except pronotum behind), mesothorax (except tegula, scutellum and its post-tergite, the posterior half of the episternum, the epimeron and the sternum), a posterior line on the hind and middle coxae and femora, on all the tibiae and tarsi, and on the abdomen a transverse fleck on the middle basal part of each tergite. Wings hyaline; stigma, costa, subcosta and anal cells green, rest of venation piceous.

Length 8-9 mm.

Head dull with coriaceous sculpture, slightly contracted behind with occipital carina well developed from gena to post-ocellar region. Labrum rounded in front. Clypeus excised in front of a depth less than half the total length of clypeus $(\mathrm{I} \cdot 0: 2 \cdot 5)$, scarcely convex, shining with only obsolescent punctures and surface sculpture. Eyes closer together in front than the length of an eye $\left(\mathrm{I} \cdot \mathrm{O}: \mathrm{I}^{4} 4\right)$. Malar space about half diameter of front ocellus. Antenna more than $\times I_{2}^{\frac{1}{2}}$ as long as width of head behind eyes $(\mathrm{I} \cdot 6: \mathrm{I} \cdot 0) ; 3$ rd segment $=4^{\text {th }}+5$ th. Distance between antennal sockets about the same as the diameter of a socket. Antennal crests project less than half the distance between them; crests continuous with lateral walls of frontal area. Posterior ocelli closer together than distance from occipital carina $\left(\mathrm{I}^{\circ} \mathrm{O}: \mathrm{I}^{\cdot} 2\right)$ and half the distance from nearest eye margin $(\mathrm{I} \cdot \mathrm{O}: 2 \cdot \mathrm{O})$; postocellar region clearly defined laterally by deep furrows, and almost $\times 2$ as broad as long $(\mathrm{I} \cdot 9: \mathrm{I} \cdot \mathrm{O})$.

Thorax normal; dull with dense coriaceous sculpture; mesoscutellum slightly roundedly convex; mesopleura without any raised protuberance. Legs with hind femur almost as long as tibia $(I \cdot 0: I \cdot 3)$; hind tarsus longer than tibia $(I \cdot I: I \cdot O)$; inner hind tibial spur about half the length of basitarsus; tarsal pulvillus on hind basitarsus about as long as apical width of basitarsus. Claws sub-bifid without basal lobe.

Abdomen with typical transverse alutaceous sculpture above. Hypopygium not emarginate laterally. Sawsheath slender and about two-thirds the length of hind tibia. Saw (Text-figs 25 and $25 \mathrm{a}$ ).

Pubescence fuscous on upper head where it is up to a length greater than the diameter of an ocellus; colourless on thorax and shorter than diameter of an ocellus.

$\tau$ as $q$ but the underthorax and abdomen are almost entirely green except for the black sutures between the sclerites, and the medial basal halves of the ist and 2nd tergites. The eyes converge more strongly in front where the distance between them to the length of an eye is as $\mathrm{I} \cdot \mathrm{O}: \mathrm{I} \cdot 7$. The malar space is but one-quarter as long as the diameter of the front ocellus. The antenna is almost twice as long as the width of the head behind the eyes.

Hind ocelli closer together than from occipital carina as I.O : I.4 and then from nearest eye margin as $\mathrm{I} \cdot \mathrm{O}: 2 \cdot 5$. Postocellar region wider than long as $2 \cdot 5: \mathrm{I} \cdot \mathrm{O}$. Tarsal pulvillus on hind basitarsus only about one-third the width of basitarsus, though one-half the width on front legs. Penis-valve as in Text-fig. 24. 
Holotype ․ Turkey: Trabzon, Soganli Gecidi, 2,600 m., on flowers of Euphorbia, 27.v.I962 (Guichard \& Harvey). B.M. (N.H.).

Paratypes. Same data, $6 \hat{\sigma}, 47$ 우. B.M. (N.H.).

This remarkable species is to be distinguished at once from all others in the arcuata-group by the green ground colour and by the punctation of the head and thorax, which are dull all over, with dense even coriaceous surface sculpture without coarser punctures: in all the other species known to me the head and thorax are coarsely punctured, \pm shining in places between the punctures especially on the temples of the head and mesoscutellum, but the underthorax and frons of head are usually dull with coarse surface sculpture.

\section{CUNEALA Zirngiebl, 1956}

This group of species was previously included in Tenthredo but is readily recognized by the long mouthparts (prelabium longer than greatest eye-measure) and the subtruncate apex of the labrum.

Whether this genus is the true Cuneala is not entirely certain, as Zirngiebl gave no full description of either the genus or type-species $C$. tricolor. He says merely that the mouthparts are elongate as in Amauronematus, ${ }^{7}$ the clypeus prism-shaped and the colour as in Tenthredo parviceps (Konow). He also says that the type is deposited in the Staatliches Naturkunde Museum, Stuttgart (where unfortunately it cannot now be found), and in correspondence Dr. Zirngiebl tells me he has no other representative of this species in his own collection.

\section{Key to Males and Females}

Face and tegula entirely black. Hind tibia and tarsus yellow, with orange apices or almost entirely infuscate. Clypeus with coarse irregular punctures obscuring the obsolescent reticulate surface sculpture. Hind tarsus of $\hat{\sigma}$ longer, but of $q$ shorter than hind tibia. $q$ either with densely pubescent basal tergites or with shining interspaces between punctures on scutellum .

Face or tegula \pm marked with yellowish white. Hind tibia and tarsus yellow with infuscate apices. Clypeus with evident reticulate surface sculpture all over between scattered shallow punctures. Hind tarsus of both $\delta$ and $q$ longer than hind tibia. क with 3 basal tergites shining and with only very sparse pubescence, but scutellum and mesopleura dull with dense microsculpture in the interspaces between punctures

2 (I) $q$ with basal tergites dull all over with dense pubescence; $\delta$ middle tergites without red markings. Interspaces between punctures on mesoscutellum dull with dense surface sculpture.

o body black with yellowish white apical margins to 4 th, $5^{\text {th }}$ and 6 th tergites and sometimes Ist and 7 th also. Legs black with tibia and tarsus yellowish white with orange apices; $\hat{\sigma}$ as $ᄋ$ but apical margins usually restricted to $4^{\text {th }}$ and 5 th tergites. IO-I $2 \mathrm{~mm}$. Mountains of C. EUROPE.

${ }^{7}$ This is not strictly true of what I here call Cuneala, because in Amauronematus it is the prementum and cardo that are elongate, while the glossa, paraglossa, galea and palps are shorter than in the species of the related genus Nematus, which has not got elongate mouthparts (c.f. Benson, 1958, figs. 388 and 389 ). In the group called here Cuneala all the mouthparts are lengthened, especially the glossa, paraglossa and palps. 
우 with Ist-3rd tergites shining medially with only very short and sparse pubescence; $\hat{\sigma}$ middle tergites usually \pm marked with red. Interspaces between punctures on mesoscutellum mostly shining with only obsolescent surface sculpture.

Colour extremely variable: $\hat{\sigma}$ and $\rho$ can be as in koehlevi, but more commonly the 3 rd and often $4^{\text {th }}$ and $5^{\text {th }}$ tergites in o are \pm marked with orange or more extensively yellow (of $\mathrm{I} 4 \mathrm{O} \%$ in B.M. only $\mathrm{I} 8$ are without some orange on abdomen); and in the commonest form of $\delta$ the whitish apical margins to the tergites are missing and the 3 rd and 4 th segments are entirely covered by a red band, while the legs are entirely black ( 85 out of $96 \sigma^{*}$ in B.M. are coloured like this); in some forms the body and legs are entirely black (f. atrata André). 9.5-I2 mm. Mountains of TURKey and eastwards to $\mathrm{N}$. IrAN $(\mathrm{I}, 000-2,400 \mathrm{~m}$.$) . . . . . . †confinis (Konow,$

3 (I) Larger species, II-I4 mm. long. Face with clypeus, labrum and base of mandibles yellowish white. Clypeus with apical excision about as deep as half its total length. Scutellum flattened medially.

Abdomen black with ist tergite \pm white, and 3 rd-6th with entire apical margins and 2nd and 7 th with apical margins laterally white

Smaller species, 8-ro mm. long. Face with clypeus and labrum black in $ᄋ$ but \pm white in $\delta$. Clypeus with apical excision usually about one-third and at most less than half its total length. Scutellum evenly convex, not flattened medially.

Tegula black with pale apical margin. $ᄋ$ abdomen black with ist and 3 rd-7th tergites \pm margins apically with white and 3 rd and 4 th may be \pm orange; $\sigma^{t}$ black but 3 rd or 3 rd and 4 th tergites may be \pm yellow. Pubescence on head and thorax long, so that the longest hairs are about as long as diameter of an ocellus. Mesonotum with interspaces between the punctures dull with surface sculpture. Transcaucasia and N. Iran . †longipes (Konow)

4 (3) Tegula mainly yellow with a small black basal spot. Pubescence on head, mesonotum and mesopleura shorter (longest hairs up to three-quarters of diameter of lateral ocellus). $\sigma^{t}$ and +9 with ist tergite enitrely white. Mesonotum with interspaces between punctures dull with surface sculpture. TURKEY . . . . . . . . . . $\dagger^{*}$ amasiensis (Kriechbaumer) sp. rev. Tegula mainly black with a yellow apical margin. Pubescence on head and thorax longer (longest hairs about as long as diameter of lateral ocellus). Ist tergite in + entirely white but in $\sigma^{*}$ black with only apical margin white. Mesonotum with interspaces between punctures shining. S.E. EUROPE (Hungary, Jugoslavia, Albania, Corfu, Greece)

dahli Klug8

\section{†Cuneala confinis (Konow, I886)}

$\dagger$ Allantus parviceps Konow, I898.

Turkey, C., N., N.E. and E.: Kayseri (I); Bolu (I and 3); Cankiri and Kastamonu (2); Trabzon (3, 4, I4, I5 and I6); Gumusane (7 and 8); Rize (8). I,0002,500 m., 96 ऽ, I35 + , I2.v-9.viii. Many on flowers of Geranium psilostemum Ledeb.

Iran : C. Elburz, Kandavan Pass, 9 km. above Siahbishe, 2,350 m., I ㅇ, 7.vi. I966 (D. B. Baker). Taken in "Lush vegetation (? former cultivation) bordering stream in semi-desert (thorn-cushion) zone".

Turkey, Transcaucasia and Iran.

${ }^{8}$ Synonym of $C$. dahli: Allantus xanthorius Kriechbaumer, syn. n. 


\section{Cuneala longipes (Konow)}

IrAN: Mazandaran, Chalus-Shahsavar Coast of Caspian Sea, $34 \hat{\delta}, 21$ ㅇ, 24. iii to 6.vi.I966, and 90 , 5 ㅇ, 20.iv to II.v.I967 (D.B. Baker). Mainly collected from flowers of Ranunculus in woodland and in forest clearings.

IRAN and TRANSCAUCASIA.

Cuneala amasiensis (Kriechbaumer)

Turkey, W., S.W. and C.: Bursa (2); Aydin (2); Ankara (I4); Corum (2); Amasya (I, 2, 3, 5, 7, 9 and I4). 50 to $560 \mathrm{~m} ., 25$ హ, 28 q.

Not known outside TURKEy.

\section{TENTHREDININAE}

\section{SCIAPTERYGINI}

\section{ELINORA Benson}

The following syntypes of Allantus found to belong to this genus in Konow's collection have been examined and the lectotypes labelled. The species are differentiated in the keys that follow.

Allantus andrei Konow. LECTOTYPE $q$ selected from I $\hat{o}$ and I $q$.

$A$. antigae Konow. LECTOTYPE ㅇ, with abdomen still intact, labelled "Barcelona " (i.e. "Hisp. prov. Catalonia " of original description), selected from 2 o and 2 o one of which had its saw mounted but no abdomen intact.

A. contiguus Konow. LECTOTYPE $\&$ with mesopleuron bearing only a yellow fleck as in original description, selected from I 0 and 4 , three of which have mesopleura almost entirely yellow.

A. dusmeti Konow. LECTOTYPE o , selected from I $\delta \hat{~ a n d ~ I ~} 9$.

A. nigritarsis Konow. LECTOTYPE , selected from I 0 and $\mathrm{I}$ ㅇ.

A. obscuratus Konow. LECTOTYPE , with yellow hind tibia and tarsus as in original description, selected from $2 \hat{\sigma}$ and 4 , three of which have hind tibia infuscate behind. Elinora obscurata (Konow) comb. n.

A. striatipes Konow. LECTOTYPE $q$ selected from I 0 and I + .

In the keys the following species, described from S.E. EUROPE or Transcaucasia, and thought also to belong to this genus, had to be omitted as no specimens have been available for study: Allantus frivalskyi Mocsáry, A. limbifer Mocsáry and A. pubescens André.

The key to the males will be found to be more unsatisfactory than that to the females, on which most of the species are based, as many of the females have not yet had males correlated with them.

Key to Females

I Orbits extensively yellow (at least hind orbits lined with yellow for their whole length)

- At least hind orbits mainly black (at most lower gena yellow) 
2 (I) Clypeus with front lobes flat and rounded or truncate apically

3 (2) Ist tergite black with at most separated pale flecks. Clypeus with surface flat and \pm punctate

Ist tergite with a broad yellowish white apical band. Clypeus convex and shining between sparse punctures. Caucasus. 7.5-9 $\mathrm{mm}$. . ornata (André)

4 (3) More punctate species. Mesopleura, scutellum and ist tergite with evident punctation and sculpture. Abdomen with tergites black and \pm laterally pale-margined apically

Sparsely punctate species. Mesopleura, scutellum and ist tergite shining and almost impunctate. Abdomen with medial orange band covering tergites 2-3 and all tergites with a yellowish white apical lateral fleck each side.

Stigma infuscate apically. Hind tibia with black-tipped apex; inner spur about as long as tibial breadth. II-I 2 mm. Morocco dulcis sp. n. (p. I 84)

5 (4) Clypeus dull with fine surface sculpture. Stigma infuscate apically. IsRaEL. I0.5 mm.

stolida $\mathrm{sp} . \mathrm{n}$. (p. I 85 )

Clypeus shining between coarse punctures. Stigma \pm unicolorous.

This species varies greatly in the amount of yellow on the orbits, antennal segments and tergites. In S.W. EUROPE the coxae are mostly black and the femora, tibiae and tarsi \pm black-lined; in some of the N. African forms the legs are almost entirely pale. S.W. Europe and N. Africa (Portugal, Spain, Morocco, Algeria (including Ahagger Mountains in Sahara Desert), Tripolitania and Cyrenaica)

6 (I) Tegula at least partly black

7 (6) Inner hind tibial spur longer than apical width of tibia

- Inner hind tibial spur shorter than apical width of tibia

8 (7) Antennae and mesopleura entirely black. Head and thorax dull with surface sculpture between dense punctures. $8 \cdot 5-10 \cdot 5 \mathrm{~mm}$. SPAin and N. Africa

limbalis (Spinola) ${ }^{10}$

Antenna with basal segment and mesopleura \pm with yellow fleck. Head and mesonotum shining between fine punctures, though on mesopleura surface is dull between the punctures. Io-I I mm. Spain and N. Africa (Morocco and Algeria)

vilarrubiai (Conde)

9 (7) Gena pale below. Abdomen black apart from apical lateral margins of tergites. 8-I I mm. N. AFrica. . . . . . . deserta (Enslin) ${ }^{11}$

Gena entirely dark. Abdomen with red girdle covering segments $3-5$ and segments from 6 and following with increasing white apical margins so that 9 is entirely white. $9 \mathrm{~mm}$. E. MEDITERRANEAN . . . asiatica (Enslin)

Io (6) 2nd and following tergites black with yellowish white lateral apical marginal flecks which, on following tergites, become more extensive till they form continuous apical bands, and on posterior segments cover the whole tergites . 2nd or 3 rd and following tergites mainly orange so that the lateral apical yellowish white flecks, which become continuous apical bands on posterior segments, are inconspicuous.

Stigma scarcely darker apically than basally. $8 \cdot 5^{-10} \cdot 5 \mathrm{~mm}$. E. MEDITERRANEAN to N. IRAN .

coniensis (Enslin)

${ }^{9}$ Synonyms of E. xanthopus: †Allantus pectoralis Kriochbaumer, syn. n. †Macrophya cognata Kirby, syn. n. $† M$. corynetes Kirby, syn. n. $\dagger M$. jugurtha Kirby, syn. n. †Allantus striatipes Konow, syn. n. $\dagger A$. andrei Konow, syn. n. $\dagger A$. tunetensis Konow, syn. n. Tenthredo adequata Enslin, I910, syn. n. Allantus diversipes Pic, I925, syn. n. Tenthredo limbergorum Forsius, I930, syn. n. T. afra Benson, I930, syn. n. $† T$. sahariensis Benson, 1954, syn. $\mathbf{n}$.

10 Synonyms of E. limbalis: †Allantus balteatus Kriechbaumer, syn. n. A. gribodoi Konow.

${ }^{11}$ Synonym of E. deserta: †Elinora guichardi Benson, syn. n. 
I I (Iо) Ist tergite almost entirely pale and stigma infuscate apically (pallipes complex)

Ist tergite with at least broad base black up to one-third of its medial length, or stigma entirely pale.

I2 (I I) Abdomen less extensively pale: 3 rd and often following tergites without continuous pale apical band. Front mesonotal lobe entirely black or with at most obsolescent pale flecks.

Abdomen more extensively yellowish white: 3 rd tergite with continuous pale apical band and $4^{\text {th }}$ onwards mainly pale. Front mesonotal lobe with conspicuous white lateral borders. 9-10 mm. TURKESTAN

pallipes (Freymonth)

I3 (I2) Larger species (I I mm.). Hind femur often with apical half \pm black. Scutellum dull and densely punctate, scarcely convex. II-I $2 \mathrm{~mm}$. TURKEsTAN

†dissidua (Konow)

- Smaller species (8-ro mm.). Hind femur entirely pale. Scutellum shining and sparsely punctate, strongly convex. 9-II mm. S. and W. CAspian Coast.

caspia (André)

I4 (Io) All femora and tibiae \pm infuscate behind . . . . . . . . . . . $\quad$ I5

- Femora at most infuscate only at base, and tibiae at extreme apex $\quad . \quad$. $\quad$ I7

I5 (I4) Gena black . . . . . . . . . . . . . I6

- Gena pale below. N. Africa. 9-1o mm. . . . . . †obscurata (Konow)

I6 (I5) Scutellum all black. Pronotum and mesopleura almost entirely yellow. Stigma scarcely darker apically. E. Mediterranean. 7.5-8 mm. barbalis (Enslin)

Scutellum with pale spot. Pronotum with only hind margin and mesopleura with only a small spot pale. Stigma conspicuously bicoloured with apical half black. N. AFrica. Io mm.

rufonigra (André)

I7 (I4) Wings subhyaline. Prelabium shorter than head capsule. Abdomen with at least posterior tergites laterally pale-margined apically. Ist tergite often \pm punctate and with surface sculpture between punctures. Inner hind tibial spur shorter than apical width of tibia

Wings infuscate. Prelabium longer than head capsule. Abdomen black with middle tergites $(3-5)$ red but other not pale-margined apically even laterally shining and very sparsely punctured species: Ist tergite impunctate and without surface sculpture. Inner hind tibial spur longer than apical width of hind tibia. Io-II mm. S.E. Europe

$\dagger$ sabariensis (Mocsáry)

I 8 (I7) Abdomen with unbroken lateral yellow stripe (tergites are entirely yellow laterally), or more extensively yellow. Antenna usually 8-segmented. Clypeus \pm shining between coarse punctures with front lobes acute or truncate. Ist tergite often without pale apical stripe. W. EUrope and N. AFrica

Abdomen without lateral yellow stripe (tergites are black basally right up to lateral margin). Antenna 9-segmented. Clypeus dull with dense surface sculpture and with front lobes pressed flat. Ist tergite with continuous pale apical stripe. Io-I $2 \mathrm{~mm}$. C. Europe to E. Mediterranean

flaveola (Gmelin)

I9 (I8) Ist tergite without pale apical band dorsally

Ist tergite with pale apical band \pm developed dorsally. tergites with continuous pale apical band. Io-I $2 \mathrm{~mm}$.

(England, France, Belgium, Portugal, Spain)

20 (I9) Stigma unicolorous yellow scarcely darker apically

Pale lateral stripe of abdomen with straight upper margin . . . $\quad$ 2I

$4^{\text {th }}$ and following

Atlantic Europe

$\dagger$ dominiquei (Konow)

2I (20) Clypeus slightly convex and shining between scattered punctures. $\quad$ 7.5-io mm.

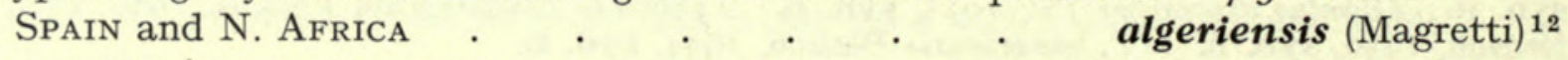

${ }^{12}$ Synonyms of E. algeriensis: †Allantus tricolor Kriechbaumer, syn. n. $\dagger A$. contiguus Konow, syn. n. 
Clypeus pressed flat against labrum and with dense surface sculpture between punctures. E. Mediterranean. $7.5 \mathrm{~mm}$. . . †parvula (Kriechbaumer)

Smaller species (under $8 \mathrm{~mm}$.). Stigma with at least lower half infuscate. Abdomen yellow-brown (? greenish in life) with a continuous black medialdorsal vitta. E. Mediterranean . . . †vittata (Kriechbaumer)

Larger species (Io-I2 mm.). Stigma with apex infuscate. Abdomen with the basal tergites black and only the lateral portions yellow, but the yellow is progressively more extensive on the apical tergites which beyond the $4^{\text {th }}$ segment have also yellow apical margins. SPAIN and N. AFrica

baetica (Spinola) ${ }^{13}$

\section{Key to MaLes}

\section{Tegulae marked with black}

Tegulae entirely pale

(I) Inner hind tibial spur longer than apical width of tibia. Stigma strongly infuscate apically .

Inner hind tibial spur much shorter than apical width of tibia. Stigma either unicolorous or \pm infuscate apically . and Algeria). 8-Io mm.

Head with shining unsculptured patches on temples. Spain and N. Africa (Morocco and Algeria). 9-Io mm.

(2) Stigma yellow often \pm brownish apically. 8 -ı mm. . . . . . . . 5 Stigma black apically with a pale base. 9-IO mm. N. AfricA rufonigra (F. André)

(4) Hind femur at least pale-lined on the outer side . Hind femur almost entirely black. Stigma brownish. 8-ro mm. N. AfricA

obscurata (Konow.) comb. $\mathbf{n}$.

(5) Clypeus with front lobes rounded or truncate apically and flattened . . 7 Clypeus with front lobes acute and convex. 9-Io mm. E. Mediterranean

maculata (Kriechbaumer)

(6) Head above antennae, mesonotum and mesopleura \pm punctate and with fine surface sculpture. 8-io mm. W. Mediterranean (Spain, Portugal and N. AFrica)

xanthopus (Spinola)

Head above antennae, mesonotum and mesopleura smooth and shining with at most, sparse obsolescent punctures. $8-9 \mathrm{~mm}$. N. Africa deserta (Enslin)

(I) Abdomen with at least one medial or apical tergite entirely pale. Often over $8 \mathrm{~mm}$.

Abdomen yellow-brown with a continuous black medial dorsal vitta and no entirely pale tergites. Hind legs mainly pale yellow except for extreme base of femur, apex of tibia and most of tarsi. Mesopleura yellow above and black below together with mesosternum. Under $8 \mathrm{~mm}$. E. Mediterranean vittata (Kriechbaumer)

9 (8) Abdominal tergites $\mathrm{I}-7$ each at least marked with black at the base medially but with the two apical tergites and hypopygium mainly yellowish white. Hind femur marked with black. Wings flavescent with unicolorous yellow stigma often \pm brownish below. Large species, IO-I $2 \mathrm{~mm}$. . . .

Abdomen with one or more of the middle tergites entirely reddish brown. If the apical tergites and hypopygium are mainly pale then the hind femur is not marked with black. Wings often hyaline and stigma usually infuscate apically or below. Often smaller species . . . . . . . . .

(9) Clypeus with front lobes truncate and flattened. Antenna 9-segmented. IO-II mm.

C. Europe to E. Mediterranean

flaveola (Gmelin)

${ }^{13}$ Synonyms of E. baetica: †Allantus antigae Konow, syn. n. $\dagger$ A. dusmeti Konow, syn. n. 
Clypeus with front lobes acute and convex. Antenna 8-segmented. Io-I3 $\mathrm{mm}$. E. EUROPE $\quad$. $\quad$. $\quad$. $\quad . \quad$. $\quad$. $\quad$ dominiquei (Konow)

I I (9) Crests above antennal sockets scarcely project beyond level of middle of the inter-antennal area

Antennal crests project strongly beyond level of middle of inter-antennal area .

I2 (I I) Clypeus flat and densely punctate. 7-Io mm.

algeriensis Magretti (N. AfRICA); boetica (Spinola) (SPAIN); dissidua (Konow), fulveola (Zhelochovstev) (TURKESTAN) and parvula Kriechbaumer

(TURKEY)

Clypeus strongly convex and \pm shining between sparse punctures. 8-ro mm. E. Mediterranean . . . . . . . . . . ornata (André)

I3 (II) Three apical tergites black, each with a yellowish white fleck each side . . I4

Three apical tergites mainly yellow, each with yellowish white fleck each side and \pm a medial black fleck. Mesonotum black except for white fleck on scutellum. 9-I I mm. E. Mediterranean . . . coniensis (Konow)

I4 (I3) Front lobe of mesonotum with lateral margins white, as is scutellum. Pale lateral flecks on apical tergites reach more than half way to middle of segment. 8-9 mm. Turkestan . . . . . . . . pallipes (Freymonth) Mesonotum usually entirely black. Pale flecks on apical tergites mostly confined to lateral ventral portions of tergites . . . . . . .

I 5 (I4) Wings \pm infuscate, with stigma pale above and infuscate below. Clypeus and mesopleura shining between scattered punctures. Inner hind tibial spur longer than apical breadth of tibia. S.E. EUROPE . . sabariensis (Mocsáry)

Wings hyaline; stigma pale basally and infuscate apically. Clypeus and mesopleura above dull with fine microsculpture between punctures. Inner hind tibial spur shorter than apical breadth of tibia. S. and W. CAspian Coast caspia (André)

\section{Elinora maculata (Kriechbaumer, I869)}

Allantus syriacus André.

A. nigritarsus Konow.

Tenthredo aulica Enslin, I9I2.

Syria, Israel, Turkey and Transcaucasia.

Elinora ornata (André, I88I)

Allantus $\dagger$ discolor Konow.

Transcaucasia.

Elinora dulcis sp. n.

ㅇ. Black with the following parts yellowish white: mandible base, labrum, clypeus, outer orbits to level of top of eyes, basal segment of antenna (rest of antennae missing in unique type), posterior half of pronotum, tegula, meso- and meta-scutella, fleck in middle of mesepisternum, fleck on metapleura, coxae (except their bases), femora, tibiae (except their extreme apices) middle of basitarsi, lateral fleck each side of 1 st and 2 nd tergites, the 3 rd, $4^{\text {th }}$ and $5^{\text {th }}$ tergites except for a lateral black fleck on each and that dorsally these three tergites are fulvous, and there is a lateral yellow fleck on the hind margin of tergites, 6, 7, and continuously on hind margin of 8 th and 9 th.

Wings slightly brownish subhyaline; basal half of stigma, extreme apex of subcosta and basal two-thirds of costa yellow; rest of venation piceous. Length $12 \mathrm{~mm}$. 
Head slightly swollen behind the eyes and shining with sparse punctation. Clypeus slightly convex but with the front lobes pressed flat and with a few scattered punctures. Frons with a medial groove widening behind. Hind ocelli further apart than from hind margin of head as $\mathrm{I} \cdot 0$ : $0 \cdot 9$, but further from eye margin than from each other (POL : OOL as $\mathrm{I} \cdot \mathrm{O}: \mathrm{I} \cdot 6)$.

Thorax strongly shining between widely-spaced obsolescent punctures; mesoscutellum evenly convex; post-tergite shorter than shortest measure of a cencher.

Legs with inner hind tibial spur about as long as apical breadth of tibia.

Abdomen normal.

Pubescence on head and thorax pale and up to a length as long as diameter of an ocellus.

Holotype ․ Morocco; Grand Atlas, Idni, 8.v. I94I (K. M. Guichard). B.M. (N.H.).

\section{Elinora stolida sp. $\mathrm{n}$.}

ㅇ. Black with the following parts yellowish white: mandible base, labrum, clypeus, outer orbits to level of top of eyes, Ist and upper side of 2nd antennal segments, pronotum, tegula, $\mathrm{V}$-shaped outer margin of front mesonotal lobe and fleck on inner side of each of the lateral mesonotal lobes, anterior three-quarters of mesoscutellum, upper half of mesepisternum, small fleck on mesepimeron and on metapleura, coxae (except extreme bases), femora, tibiae (except extreme apices) basitarsus except for a fleck at extreme base and extreme apex, fleck on lateral hind margin of Ist and following tergites progressively longer from the ist tergite backwards, so that on the $5^{\text {th }}$ and following tergites the hind margin is continuously pale.

Wings slightly brownish subhyaline; front half of stigma, costa, subcosta (front half of $S c+R)$ and veins at extreme base of wings yellow; rest of venation piceous. Length ro $\mathrm{mm}$.

Head shining with very fine surface sculptures. Clypeus slightly convex with front lobes pressed flat and the whole surface dull with dense surface sculpture. Frons with a L-shaped medial groove. Hind ocelli further apart than from hind margin of head as $1 \cdot 0: 0 \cdot 7$, but further from the eye margin than from each other (POL : OOL as $I \cdot 0: I \cdot 7)$.

Thorax shining between sparse punctures, which become denser at front of mesonotum and in middle of mesonotum, where they are scarcely further apart than the diameter of a puncture. Mesoscutellum slightly convex and not separated medially from the raised centre of the posttergite which is about as long as the shortest measure of a cencher.

Legs with inner hind tibial spur scarcely three-quarters as long as apical width of tibia.

Abdomen normal.

Pubescence on head and thorax pale and up to a length as long as the diameter of an ocellus.

Holotype ㅇ. Israel: Jerusalem, I5.iii.I923 (P. A. Buxton). B.M. (N.H.).

\section{Elinora asiatica (Enslin)}

TURKEY.

\section{Elinora coniensis (Enslin)}

Allantus (Tenthredo) kaveli Muche, I962, syn. n.

TURKEY: Ankara (57). I $\delta^{\hat{t}}$ and I 9 ; Kayseri (on flowers of Lepidium, Muche, I962).

N. Iran: W. Elburz, Qazvin, c. 760 m., 2 ô, I + , 25.iv.1967 (D. B. Baker).

Turkey, Transcaucasia and N. Iran.

Elinora caspia (André)

S.E. Russia, Transcaucasia and Iran. 


\section{Elinora barbalis (Enslin)}

SYRIA.

\section{Elinora flaveola (Gmelin)}

$\dagger$ Allantus orientalis Kriechbaumer.

C. and E. Europe and Turkey.

†Elinora parvula (Kriechbaumer) comb. n.

TURKEY.

\section{†Elinora vittata (Kriechbaumer) comb. n.}

ISRAEL and IRAQ.

\section{TENTHREDININAE SGIAPTERYGINI}

\section{SCIAPTER YX Stephens}

Previous keys to world Sciapteryx were compiled by Konow, I908, KuznetzovUgamskii, I929 and the Caucasian species by Dovnar-Zapolskii,, I930.

The following species, from studies of the types, are now placed in other genera as shown:

Sciapteryx galerita Konow (Sikkim) = Tenthredo galerita (Konow) comb. $\mathbf{n}$.

Sciapteryx kozlovi Konow (Tibet) $=$ Tenthredo kozlovi (Konow) comb. n.

Sciapteryx gilva Konow (Tibet) = Rhogogaster gilva (Konow) comb. $\mathbf{n}$.

Sciapteryx virescens Konow (Tibet) $=$ Rhogogaster virescens (Konow) comb. n.

Sciapteryx caucasica Dovnar-Zapolskǐ (Caucasus) and S. montana Dovnar-Zapolskǐ (Caucasus) cannot be placed because they are based on inadequately described males and are excluded from the key below.

All the species of this genus have size 7-10 $\mathrm{mm}$.

\section{Key to Species Males and Females}

I Gena dull with dense surface sculpture between punctures or with punctures closer together than their diameters. + hypopygium evenly or acutely emarginate each side of middle . . . . . . . .

- Gena behind eyes, shining, with punctures obsolescent or more widely spaced than their diameters. + hypopygium not emarginate each side of middle .

2 (I) Fore wings \pm infuscate or milky and $S c+R$ not longitudinally bicoloured. Inner hind tibial spur not longer than apical breadth of tibia and only 4-5 times as long as broad.

Hypopygium in + slightly emarginate each side of middle 
- $\quad$ Fore wings subhyaline and the fused $S c+R$ paler in front $(S c)$ than behind $(R)$. Inner hind tibial spur longer than apical breadth of tibia and 7 or 8 times as long as broad

3 (2) $S c+R$ and also usually $C$ in fore wing pale yellow or brown Wings milky or with the fore wings \pm infuscate. Stigma pale with or without dark apex

$S c+R$ and $C$ in fore wing mainly black. Wings almost uniformly infuscate. Stigma pale with dark apex. Atlantic Europe and Mediterranean

4 (3) Stigma of fore wing bicoloured with dark apex and pale base. $C$ of fore wing

$\dagger$ soror Konow pale as in $S c+R$. Fore wings \pm infuscate . . . . . . .

Stigma pale without dark apex and $C$ infuscate apically. Wings uniformly milky. E. Mediterranean .

5 (4) Tegula entirely yellowish white

†lactipennis Konow

- Tegula with most of basal half black. E. Mediterranean . (costalis) 6

(5) Inner orbits and lower half of outer orbits lined with white in $\widehat{\delta}$ and $q$; $\widehat{\delta}$ with face below antennae entirely white; + with interantennal area pale marked CORSICA . . . . . . . . . . † costalis corcyrensis Benson

Only the inner orbits above pale-lined in $q$ and interantennal area entirely black; in $\delta^{t}$ whole inner orbits and lower outer orbits pale-lined but clypeus \pm marked with black. C. and E. Europe

costalis costalis (Fab.)

7 (2) Darker species, flagellum of antenna and, even in $\hat{\sigma}$, base of clypeus, most of face between antennae and clypeus, mesopleura, \pm stigma black. Abdomen without a continuous pale lateral band and with no entirely pale apical sternites. Antenna with flagellar segments all longer than broad . .

Paler species, underside of flagellum, most of clypeus and face below antennae even in + , \pm fleck on mesopleura, most of stigma, a broad lateral band on the abdomen and at least I or 2 entire apical sternites yellowish white. Antenna with 7 th and 8 th segments as broad as long $(\hat{\delta})$ or broader than long (ㅇ). Head and thorax with aeneus reflections. E. Mediterranean

†laeta Konow

8 (7) Inner orbits in $\widehat{o}$ and $q$ pale-lined to top of eyes. Head and thorax often with cupreous or aeneus metallic reflections. Stigma yellowish white infuscate below or at apex

Inner orbits in $\hat{\sigma}$ and $q$ at most only pale-lined on lower half, with a small fleck at top of eye. Head and thorax carbonarius or with slight bluish, purplish or greenish reflections. Stigma piceous. क hypopygium slightly and evenly emarginate each side of middle. W. and C. EUROPE

consobrina Klug

9 (8) Stigma pale \pm infuscate below. Labrum and \pm base of clypeus pale. $q$ hypopygium sharply excised each side of middle (as in laeta). E. Mediter-

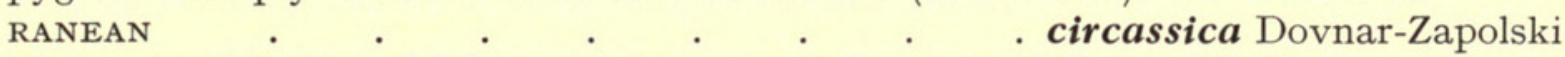

Stigma pale at base and infuscate at apex. Labrum and clypeus black except at most for a lateral pale fleck each side of clypeus. + hypopygium evenly emarginate each side of middle (as in consobrina). S.E. Europe (Thrace)

byzantina $\mathrm{sp}$. n. (p. I 88 )

Io (I) Stigma bicoloured with infuscate apex or mainly infuscate . . . . . $\quad$ II

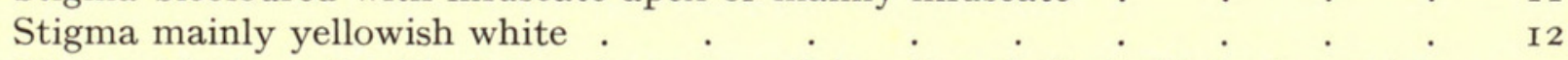

I I (Iо) Stigma bicoloured with infuscate apex. Veins $C$ and $S c+M$ in fore wing entirely pale. Tegula black with narrow white apex. All legs black with a white line above or on outside. S.E. Mediterranean †cleopatra Benson

Stigma mainly infuscate. Only base of $C$, and $S c$ pale. Tegula black. Legs mainly black. CRIMEA

I 2 (Io) Tegula entirely yellowish white. TURKestan

semenowi Jakovlev

Tegula black with only the apex yellowish white. Turkestan

nigriventris André ${ }^{14}$

hauseri Forsius

${ }^{14}$ Synonym of $S$. nigriventris: Sciapteryx costalis vernalis Kuznetzov-Ugamskil, syn. n. 


\section{$\dagger$ Sciapteryx soror Konow}

Turkey, E.: Gumusane (II). I ô, I .

Elsewhere only in Atlantic and Mediterranean Europe (Britain, W. France, Switzerland, Spain and Italy). This species forms an Atlantic/Continental species pair with $S$. costalis F. (Benson, I952).

\section{$\dagger$ Sciapteryx lactipennis Konow}

Transcaspia, Iran, Transcaucasia and Israel.

\section{Sciapteryx levantina André}

Syria and Lebanon.

\section{$\dagger$ Sciapteryx laeta Konow}

Turkey, E.: Gumusane (II). 4 ơ. 8 ㅇ.

TURKEy and Transcaucasia.

\section{*Sciapteryx circassica Dovnar-Zaposkiî}

Turkey, E.: Gumusane (II); Trabzon (3 and I7). 3I ô, 28 ㅇ.

TURkey and Transcaucasia.

\section{Sciapteryx cleopatra Benson, I954}

EGYPT and ISRAel.

\section{*Sciapteryx byzantina sp. $\mathrm{n}$.}

ㅇ․ Black with the following parts yellowish white: labial palps, inner orbits above level of antennae, hind edge of pronotum, front half of tegula, extreme apex of femora and \pm outer edge of tibiae, \pm base of basitarsus and apical margin of all tergites. Wings hyaline: basal half of stigma, extreme apex and base of costa and subcosta (front half of $S c+R$ ) yellowish white; rest of venation piceous. Length 8-9 $\mathrm{mm}$.

Head and thorax normal, dull with dense punctures closer together on gena than their diameters and the interspaces \pm with fine surface sculpture. Antenna with all flagellar segments longer than broad. Inner hind tibial spur longer than apical width of tibia and about $\times 7$ or $\times 8$ times longer than its own basal width. Abdomen dull with dense transverse surface sculpture.

Hypopygium emarginate each side of middle saw. $\widehat{c}$ as in $q$ apart from sexual characters but that the clypeus has a small whitish fleck each side and the pale margin of the inner orbits reaches to bottom of eyes.

Holotype o. Turkey, N.W.: Istanbul, Belgrat Orman, at sea level, 25.iii.62 (Guichard \& Harvey). B.M. (N.H.).

Paratypes. Same data, I5 $\hat{0}, \mathrm{I}$ q. Turkey, N.E.: Rize at sea level, I + , 22.iv.I959 (Guichard). B.M. (N.H.). 


\section{TENTHREDINAE}

\section{MACROPHYINI}

\section{Pachyprotasis rapae (L.)}

Turkey, N.E.: Giresun (7); Trabzon (3, 4, I5 and I7). 20 ô, 20 ㅇ.

N. temperate Holarctic species.

\section{MACROPHYA Dahlbohm}

Two major sections of the genus are defined as species-groups in the present paper and keys are given for the species of these groups from Europe and S.W. Asia.

\section{Macrophya punctumalbum (L.)}

Turkey, N. and C.: Amasya (6); Samsun (8). Io ㅇ․

N. Iran: Mazandaran, Panjak Rostaq, 860-900 m., I +, 29.iv. I967 (D. B. Baker).

\section{Macrophya albicincta (Schrank)}

Turkey, W., N. and N.E.: Bursa (3, 9); Bolu (I); Samsun (9, I5, etc.); Giresun (7); Trabzon (4, 7, I7); Rize (2). 36 o, 39 ‥

Europe, to Transcaucasia, N. Iran, W. Siberia.

\section{Macrophya crassula (Klug)}

Turkey, W., S., N., and N.E.: Bursa (3 and 9); Mersin (6 and 7); Sinop (I); Samsun (9, IO, 2I, etc.); Trabzon (I7, etc.); Artvin (2). 33 ô, 39 우.

C. and S. Europe to Transcaucasia.

\section{Macrophya consobrina Mocsáry}

TURKEY and Transcaucasia.

Macrophya pallidilabris A. Costa

Turkey, W. and N.E.: Bursa (4, 5 and 9); Gumusane-Trabzon (II). 6 ô, 6 q. C. Europe to Transcaucasia.

Macrophya erythrocnema A. Costa

Turkey, N.E.: Rize (8); Artvin (3). 2 ㅇ.

S. Europe to Transcaucasia.

\section{$\dagger$ Macrophya rufipes orientalis Moscáry}

For nec $M$. orientalis Mocsáry; Benson, I954 vide $M$. diaphenia sp. n. Turkey, C. and E.: Ankara (35); Gumusane (7). 3 ㅇ. 
In this race the red markings on the middle tergites ( 3 and 4 ) are entirely absent.

In N. Africa the species is represented by $M$. rufipes ruficincta Konow, stat. n., which differs from the typical race in having a black clypeus and black hind tibia and tarsus in both sexes.

\section{Macrophya sanguinolenta (Gmelin)}

Turkey, N.E. and E.: Trabzon (3); Rize (8); Erzurum (9). 2 ô, I +.

Europe, Turkey and Transcaucasia.

\section{The BLANDA-DUODECIMPUNCT ATA-group}

Representatives of this species-group are recognized by the presence of a small appendage behind the metepisternum as a separate sclerite between the hind coxa and the Ist tergite.

In addition to the species from Europe and S.W. Asia keyed below, M. apicalis Smith (JAPAN), M. ignava Smith (JAPAN), M. infumata Rohwer (E. Siberia) as well as $M$. fumator Norton (N. AmerICA) belong to this group.

\section{Key to Males and Females of Europe \& S.W. Asia}

I

2 (I) Hind legs not marked with red.

- Hind legs partly red

3 (2) Wing membrane yellowish; stigma and venation yellowish brown. Hind tarsus black. Europe, Asia Minor, and Siberia to Japan

duodecimpunctata (L.)

Wing membrane subhyaline. Stigma and venation infuscate. Hind tarsus with apical segments white. Transcaucasia and Iran

4 (3) Hind coxa with a white fleck laterally or beneath

longitarsus Konow

Hind coxa entirely black. Europe, S.W. Asia to Iran and Siberia

annulata (Geoffroy)

5 (4) of with hind tarsus normal (4th segment much longer than broad in ventral view (Text-fig. 27). + hypopygium only slightly emarginate apically each side

ô with hind tarsus swollen (4th segment scarcely longer than broad in ventral view) (Text-fig. 28). + h hypopygium excised apically each side of middle.

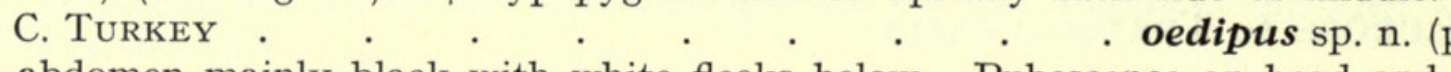

6 (5) ô abdomen mainly black with white flecks below. Pubescence on head and thorax up to as long as diameter of an ocellus. Penis-valve Text-fig. 33. (o unknown). Mountains of E. Turkey . . hamata sp. n. (p. 194)

$\delta$ abdomen \pm red-banded and without white flecks below. Pubescence on head and thorax not longer than half diameter of an ocellus. Penis-valve as in Text-fig. 32. Europe, Asia Minor, to Iran and Siberia

blanda (Fabricius) 
7 (2) Metepisternum with lower two-thirds shining and without surface sculpture apart from hair follicles. Frons shining between punctures and without a continuous medial groove. Wings subhyaline. of with pale yellow front and middle femora and tibia strongly contrasting with its hind legs and with the red front and middle legs of the + . Europe, Asia Minor to

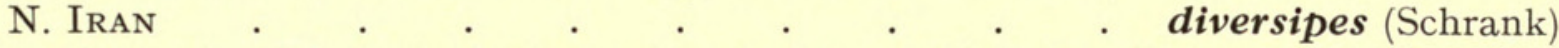

Metepisternum dull with dense surface sculpture all over. Frons dull with dense surface sculpture and with a deep medial groove reaching from front ocellus to interantennal area.

Wings uniformly slightly infuscate. $\widehat{\sigma}$ with front and middle femora and middle tibia reddish as in the hind legs and as in the ㅇ․ Iran

diaphenia sp. n. (p. I95)

\section{7 ham.}
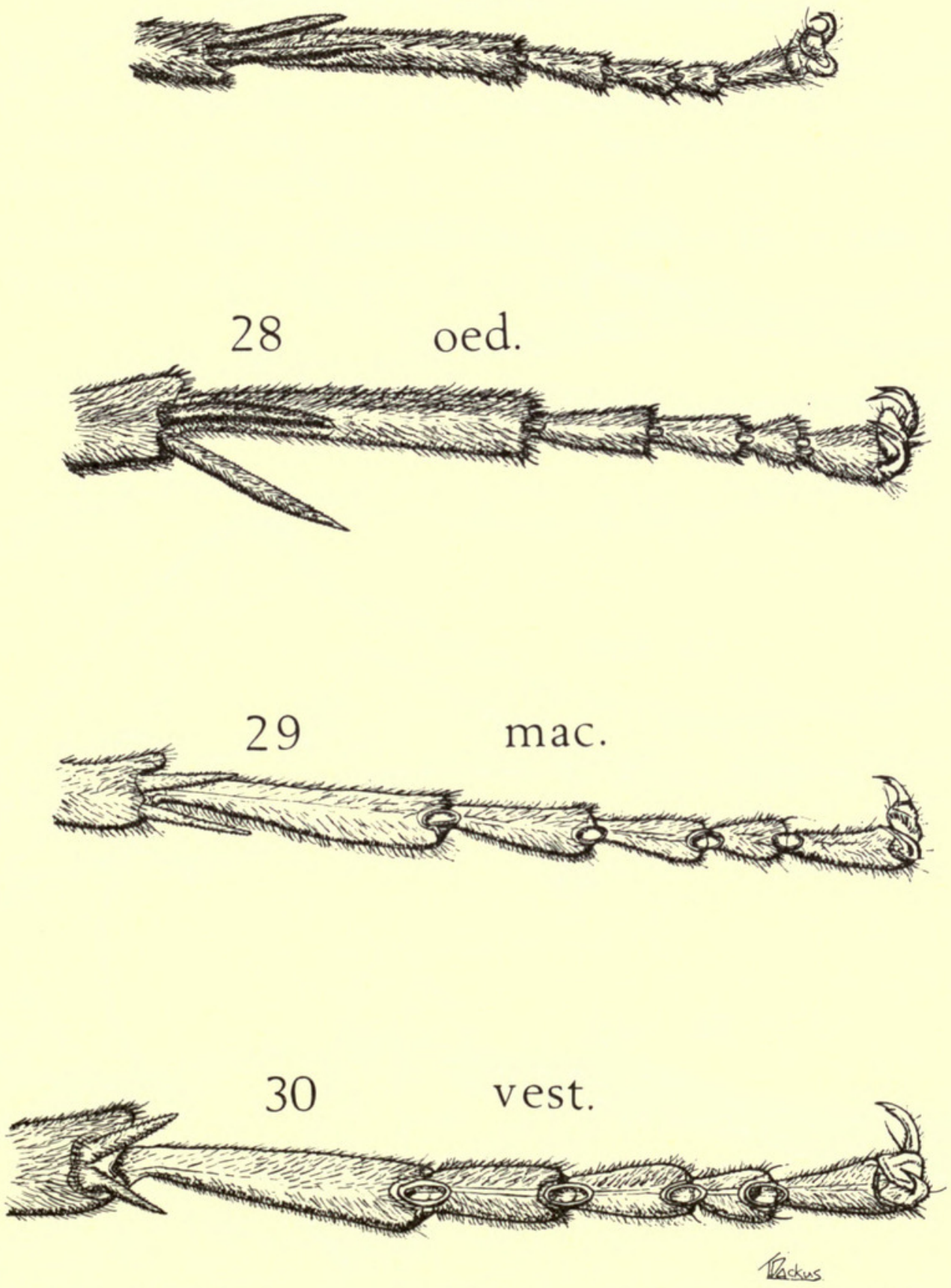

Figs. 27-30. ôt hind tarsus: 27, Macrophya hamata sp. n.; 28, M. oedipus sp. n.; 29, Tenthredo maculata; and 30, T. vestita. 


\section{Macrophya duodecimpunctata (L.)}

Turkey, N.: Samsun (2 and 6).

Europe, Turkey and Siberia to Japan.
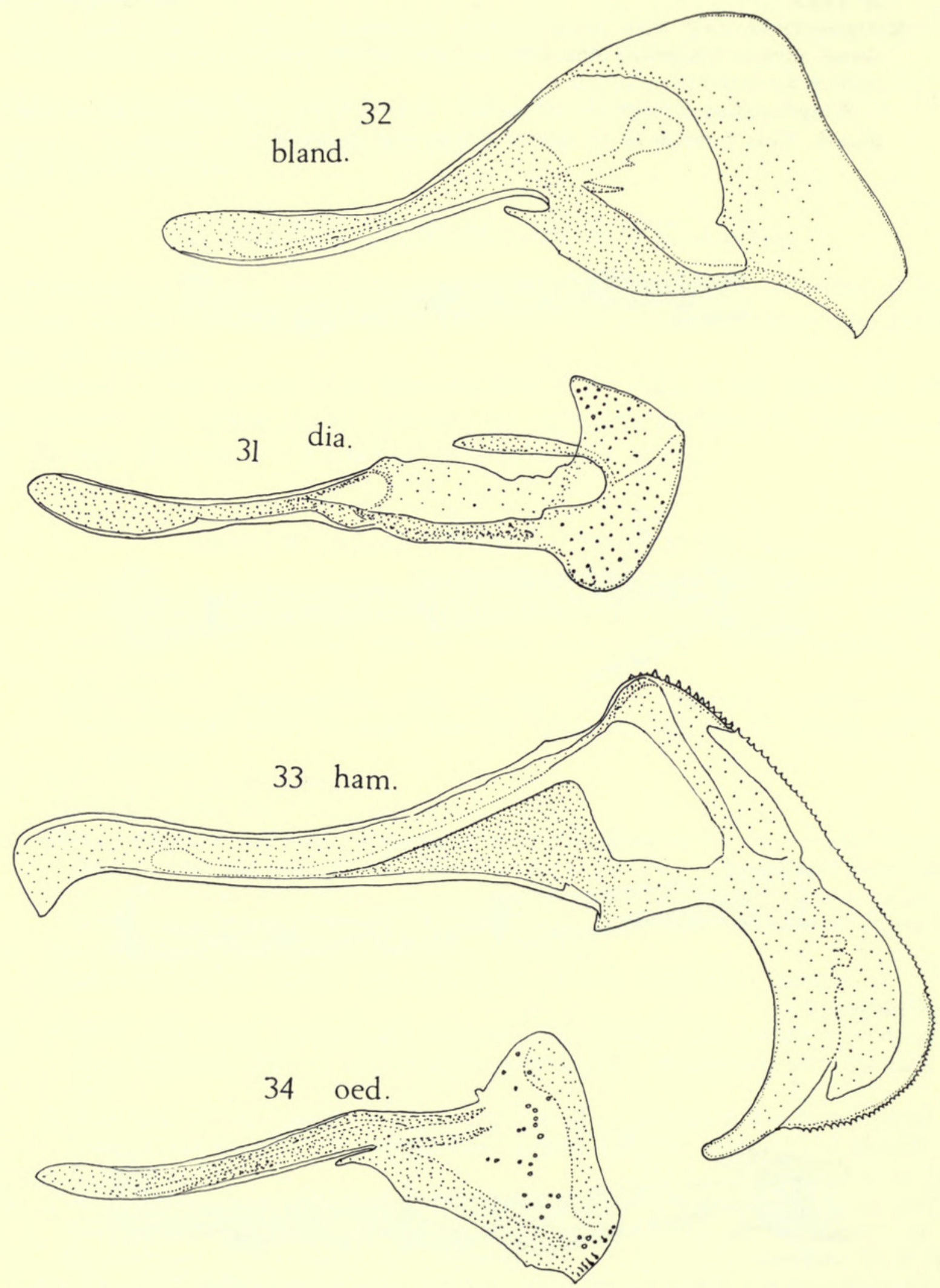

Figs. 3I-34. Macrophya penis-valves in lateral view: 3I, diaphenia sp. n.; 32, blanda; 33, hamata sp. n.; and 34, oedipus sp. n. 


\section{Macrophya longitarsus Konow}

Iran: Mazandaran, Chalus-Shahsavar coast of Caspian Sea. v-vi.Ig66 (D. B. Baker).

TransCaUCASIa and Iran.

\section{Macrophya annulata (Geoffroy)}

Turkey, C. and N.: Ankara (I5); Samsun (9). 4 ô, 2 q.

IrAN: Mazandaran, Chalus-Shahsavar coast of Caspian Sea, v. I966 (D. B. Baker). Europe, S.W. Asia to Iran and Siberia.

\section{Macrophya blanda (Fabricius)}

Turkey, W., S., C., N.E. and E.: Usak, Bulgaz Dag Mts., Kizilcahaman, I,00o m., I ô, 2 ㅇ, 26.v-I6.vi. I965 (Demelt Coll., Gembloux); Mersin (6, 7 and I4); Ankara (3I and 39); Amasya (3, 7, 9 and I3); Konya (3); Samsun (I0); Giresun (2); Trabzon (3 and I5); Artvin (3); Erzurum (5, 6). I8 o, 48 q.

Iran: Mazandaran, Chalus-Shahsavar Coast of Caspian Sea, v. Ig66 (D. B. Baker). Europe, Turkey, Transcaucasia, Iran and Siberia.
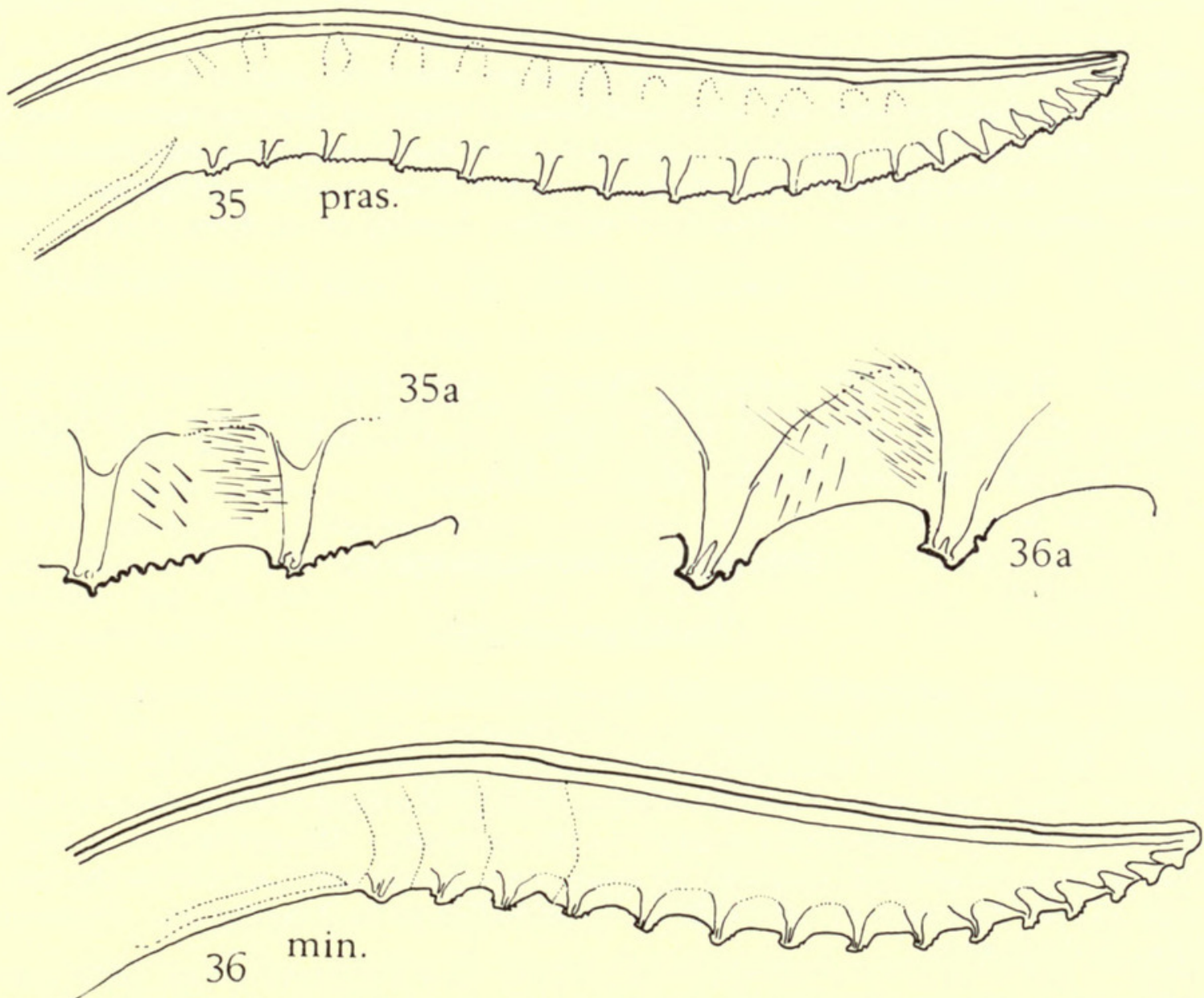

FIgs. 35-36. Macrophya saws: 35, prasinipes; 36, minerva sp. n. 35a-36a. Enlarged Ioth and IIth teeth from apex of saws: $35 \mathrm{a}$, prasinipes; $36 \mathrm{a}$, minerva sp. n. 


\title{
*Macrophya oedipus sp. n.
}

\author{
(Text-figs, 28, 34)
}

o. Black with tergites 3 and 4 and sometimes also 5,6 and $7 \pm$ red laterally and the following parts white: labrum, \pm front of clypeus, posterior extra sclerite on metepisternum; front face of all coxae and \pm lateral fleck on hind coxae, front face of fore and middle femora and tibiae, front tarsus, most of middle tarsus (except line on back of basitarsus, and the clawbearing segment) and lower edge of hind femur. Wings hyaline; stigma and venation black.

Length 9-I I mm.

Head with mouthparts normal; malar space about one-fourth of distance between antennal sockets; 3rd antennal segment about as long as $7+8+9$; frontal area not clearly defined; frontal groove running from front ocellus to interantennal area; hind ocelli closer together than from hind margin of head as $\mathrm{I} \cdot 0: \mathrm{I}^{\circ} 4$; and from eye margin as $\mathrm{I} \cdot 0: 2 \cdot 3$.

Thorax with rounded convex mesoscutellum, medially carinate over posterior half and with minute extra appendage attached to posterior margin of metepisternum, which is dull medially with dense surface sculpture. Legs with swollen hind tarsus so that the 3 rd tarsal segment in ventral view is almost as broad as long (Text-fig. 28). Claws bifid with the inner tooth longer and stouter than the end tooth. Abdomen normal with penis-valve as in Text-fig. 34 .

Punctation: Head very densely and coarsely punctured on the frontal area and though the punctures are sparse on the temples, the surface between the punctures is dull with dense coriaceous sculpture. On the thorax the punctures are smaller and more evenly spaced but the interspaces are likewise dull with dense coriaceous sculpture. Abdomen dull with dense transverse alutaceous sculpture.

Pubescence clothing whole of insect very short, nowhere exceeding about half diameter of an ocellus.

ㅇ a $\sigma^{*}$ in colour but labrum and clypeus \pm infuscate, the front half of the mesoscutellum is white, the legs are black except for white as follows: a fleck on the underside of the fore and middle coxae and the side of the hind coxae, a line on the front of the fore femur, tibia and basitarsus and \pm on the apex of the middle femur. In structure as $\sigma^{t}$ except for sexual segments; hypopygium emarginate behind each side of middle. Length $12-13 \mathrm{~mm}$.

Holotype ô. Turkey, C.: Amasya, 500 m., 3I.v.I959 (K. M. Guichard). B.M. (N.H.).

Paratypes. Turkey, C.: Amasya, 500 m., 5 ô, I ㅇ, 22-24.v. I959, 2 ㅅ․ 2 ㅇ, 29.V.I959, 4 ô, I-2.vi.I959, I + , 6.vi.I959, 2 ô, I ㅇ, 9.vi.I959, and 400 m., 6 ô, 4 ㅇ, 30.v.I959 (K. M. Guichard). B.M. (N.H.).

\section{*Macrophya hamata sp. $\mathbf{n}$.}

(Text-figs. 27, 33)

o. Colour as in M. oedipus but that the clypeus is black except for its front margin, the fore and middle femora and tibiae are only lined with white in front, the hind coxae, though whiteflecked below, have no lateral white fleck, the abdomen has the red reduced to at most a lateral fleck each side of the 2nd tergite, but has a white fleck on the hind lateral corners of each of the 3rd to 6th tergites, and white apical margins to the sternites. The pubescence is much longer than in $M$. oedipus, blanda and annulata; on head, mesonotum and mesopleura the hairs are up to as long as the diameter of an ocellus. Penis-valve as in Text-fig. 33. Otherwise as in $M$. blanda. ㅇ unknown.

Holotype ô. Turkey: Artvin, above Artvin, I,800 m., 6.vi.rg62 (K. $M$. Guichard \& D. Harvey). B.M. (N.H.). 
Paratypes. I $\hat{\sigma}$ (same data), I $\hat{\delta}$ (likewise but at $900 \mathrm{~m}$.$) and I \hat{\sigma}$, Turkey: Trabzon, Hamsikoy, I,245 m., 22.v.1962 (Guichard \& Harvey). B.M. (N.H.).

\section{Macrophya diversipes Schrank}

Turkey, W., C., N.E. and E.: Mugla (8); Mersin (8); Ankara (9, 37 and 39); Corum (2); Amasya (I, 2, 3, 5 and 7); Artvin (2 and 6); Gumusane (I and IO); Erzurum (I, 4, 5, 8, Io and II). 26 万, 4I + .

C. and S.E. Europe, Turkey, Transcaucasia and N. Iran.

\section{Macrophya diaphenia sp. $\mathrm{n}$.}

(Text-fig. 3I)

Macrophya orientalis Mocsáry; Benson, 1954, nec Mocsáry.

đ. Black with the following parts yellowish white: labrum, front half of clypeus, fore tibia and tarsus, apex and inner side of middle tibia, and middle tarsus (except apical segment); trochanters brown; red are the fore femur, middle femur and basal outer side of middle tibia, hind femur and tibia (except its extreme apex). Length II-I $2 \mathrm{~mm}$.

Wings brownish-infuscate, paler towards base. Basal half of stigma and basal three-fourths of costa brown; rest of venation black.

Head contracted behind eyes. Malar space one-third as long as distance between antenna or diameter of front ocellus. Antenna with 3 rd segment about as long as 4 th and 5 th. Frons with a deep medial groove reaching from front ocellus to interantennal area. Hind ocelli closer together than from hind margin of head as $\mathrm{I} \cdot 0: \mathrm{I}^{\cdot} 7$, and from eye margin as $\mathrm{I}^{\circ} \mathrm{O}: \mathbf{2}^{\cdot} \mathrm{O}$.

Thorax with slightly convex mesoscutellum, carinate medially for posterior half; metepisternum dull medially with dense surface sculpture and with a small posterior appendage.

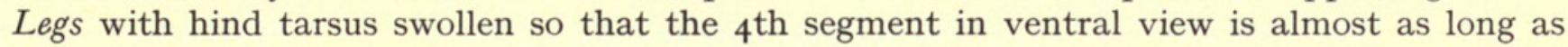
broad.

Abdomen normal. ot penis (Text-fig. 3I) not distinguished from that of $M$. diversipes.

Punctation dense on head and thorax; interspaces shining on head, but on mesonotum and mesopleura the interspaces are dull with dense surface sculpture.

Pubescence dense all over insect and very short so that nowhere on head and mesonotum are the individual hairs as long as the diameter of an ocellus.

우 as $\sigma^{t}$ but the stigma of the fore wing is entirely yellowish brown and all the legs have the femur and tibia red and the trochanters and tarsus infuscate, and the hind tarsal segments are not so swollen, the $4^{\text {th }}$ being $\times \mathrm{I}_{2}$ as long as wide in ventral view. Hypopygium slightly emarginate each side of middle. Saw not distinguished from that of $M$. diversipes.

Holotype. §. S.W. Iran: Kuh Sefid, nr. Bazuft, (Escalera Coll.). B.M. (N.H.).

Paratypes. Same data, $3 \hat{\jmath}, 2$ 우 ; N. Iran: Elburz Mountains, Mt. Demavend, 2,800 m., I ㅇ, vii.I966 (L. G. Higgins). B.M. (N.H.).

\section{The POSTICA-group}

Species with eyes converging in front and abdomen with at least a white band on the Ist tergite and lateral flecks on some of the others; at least front and middle legs. hind coxa and base of hind femora mainly yellow or orange. 


\section{Key to Males and Females}

Either mesonotum entirely dull with surface sculpture between fine punctures and front lobe usually with dark adpressed pubescence shorter than diameter of front ocellus or hind legs with tibia and tarsus mainly black. (o hypopygium strongly emarginate) .

- Mesonotum with the interspaces between the punctures shining and the pubescence on the front lobes pale, and usually outstanding and longer than diameter of front ocellus; hind legs with tibia mainly yellow or orange .

2 (I) Stigma of fore wing and hind tibia and tarsus mainly orange or yellow (except in $\sigma^{t}$ aphrodite). Pubescence short, dark and adpressed on front lobe of mesonotum .

Stigma of fore wing and hind legs mainly black (subsp. arpaklena Ushinskiř, from Turkestan and N. IRAN has $q$ hind tarsus with segments $2-4$ white as in $\hat{\sigma}$, and abdomen with pale flecks reduced). Europe, N. AfricA, Asia Minor to TURKESTAN

montana (Scopoli)

3 (2) Head above dull with dense surface sculpture between punctures. Post-tergite of scutellum longer medially than a cencher . . . . . .

Head above shining between punctures, which are very sparse and obsolescent on middle of temples. Asia Minor to S.W. Iran

Costa of fore wing infuscate, darker than the yellow stigma. Scutellum with depressed posterior third dull with dense sculpture and with anterior twothirds shining between sparse punctures . . . . . . .

Costa of fore wing coloured the same as the yellow stigma. Scutellum with the posterior half dull with dense sculpture and the anterior half shining between scattered punctures. Lebanon, Israel, Transcaucasia and Iran

ottomana Mocsáry

5 (4) Temples between postocellar region and eyes dull, with surface sculpture between the dense punctures: $\delta^{t}$ hind tibia mainly orange and brown. C. and

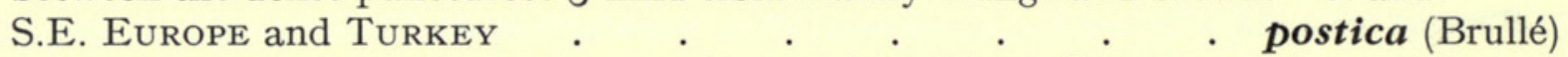

Temples between postocellar region and eyes with shining interspaces between scattered punctures; ot hind tibia mainly black. Cyprus . †aphrodite Benson

6 (I) Stigma of fore wing darker apically than basally. Hind tarsus black. 우 hypopygium not emarginate each side $\quad . \quad . \quad . \quad . \quad . \quad . \quad$.

Stigma of fore wing unicolorous brown. Hind tarsus reddish brown. 우 hypopygium strongly emarginate behind each side of middle. S.E. Europe and TURKEY

superba Tischbein

7 (6) Abdominal segments of $q$ ringed with pale apical margins to tergites and sternites; $\hat{\sigma}$ abdomen yellow above, except for the bases of the tergites medially, and entirely yellow laterally and ventrally. Saw with shallow teeth (Text-fig. 35 and $35 \mathrm{a})$. Transcaucasia

prasinipes Konow

Abdomen in black except for the yellow apical margins of the tergites medially;

(o unknown). Saw with prominent teeth (Text-figs. 36 and 36a). GreECE

minerva sp. n. (p. I97)

\section{Macrophya montana montana (Scopoli)}

Turkey: Amasya (2, 5 and 7); Samsun (I0); Sivas (3); Rize (8). I2 0 , I4 ㅇ. . (Ssp. arpaklena Ushinskij in Turkestan and N. Iran, Mazandaran on the Caspian Sea Coast, iv-v.1965-rg66 (D. B. Baker)).

Europe, N. Africa, Turkey, Transcaucasia, Iran and Turkestan. 
*†Macrophya cyrus Benson, I954

Turkey, C. and E.: Amasya (I, 2, 3 and 7); Nigde (4); Gumusane (I3); Erzurum (I, 4, 5, 6 and 8). 5I ô, 49 +.

TURKEY and S.W. IRAN.

\section{Macrophya ottomana Mocsáry}

Lebanon, Israel, Transcaucasia and Iran.

\section{Macrophya postica (Brullé)}

Turkey, S.W., S.C., N., N.E. and E.: Aydin (I and 2); Mugla (2, 5 and 7); Antalya (5 and 89); Mersin (I, 2 and 4); Ankara (I2); Amasya (I, 2, 5, 7 and I4); Sinop (3 and 4); Samsun (I0); Artvin (6); Gumusane (I3); Erzurum (4). Many $\sigma^{*}$ and $q$.

\section{$†$ Macrophya aphrodite Benson, I954}

Cyprus.

\section{Macrophya superba Tischbein}

Turkey, N., C., N.E. and E.: Izmit, Alem Dag, 600 m., I 9, 26-30.vi. I966 (Demelt Coll. Gembloux); Ankara (2I, 35 and 39); Cankiri, Isik Dag, I,200 m., 2 , 25.vi.rg66 (Demelt Coll. Gembloux); Amasya (I, 2, 3 and 7); Nigde (5); Artvin (2) Gumusane (I); Erzurum (4). 35 ô, 42 ㅇ․

S.E. Europe and Turkey.

\section{Macrophya prasinipes Konow}

TRANSCAUCASIA.

\section{Macrophya minerva sp. $\mathrm{n}$.}

(Text-figs. 36, 36a)

ㅇ. Black with the following parts yellowish white: palps of mouthparts, labrum, clypeus, hind margin of pronotum, tegula (except at base), apices of coxae, trochanter, upper outer face of hind coxa, femora (except small inner basal fleck) and tibiae of all legs (except apex of hind pair) and fore and middle tarsus (except for broken black line on inner side), apical margin of ist tergite and lateral dorsal margin of 3 rd and following tergites.

Wings subhyaline; base of stigma, base of $C$, and $S c$ (front half of $S c+R$ ); rest of venation piceous becoming paler at extreme base. Length: I I $\mathrm{mm}$.

Head normal, slightly contracted behind eyes. Malar space about as long as 2 facets of compound eye. Flagellar segments of antenna all longer than broad. Occipital carina complete. Posterior ocelli about as far apart as from occipital carina (POL $=$ OOCL); and closer together than from nearest compound eye margin (POL: OOL $=\mathrm{I} \cdot \mathrm{O}: \mathrm{I} \cdot 5$ ).

Thorax normal, without the extra metepisternal sclerite between the hind coxa and ist tergite. Mesoscutellum slightly convex.

Abdomen normal; hypopygium only slightly emarginate each side. Saw (Tet-xfigs. 36 and $36 \mathrm{a})$. 
Punctation. Head shining with dense punctures on frons, inner orbits and postocellar region but becoming obsolescent on temples and finer and denser on outer orbits. Thorax shining between punctures \pm as far apart as their diameters, though more widely spaced on the middle of the mesoscutellum and much denser on the underthorax. Abdomen densely alutaceous transversely.

Pubescence on head and thorax dense and pale and up to about as long as twice the diameter of a hind ocellus; on abdomen about half this length and pale and dense and recumbent.

Holotype +. Greece: Soufli, I + , 5.v. I960 (Guichard \& Harvey). B.M. (N.H.).

Distinguished from other members of the postica-group in the key above.

\section{NEMATINAE}

\section{GLADIINI}

\section{Cladius pectinicornis (Geoffroy)}

Turkey, N. and C.: Samsun (6 and 2I); Amasya (2, 3 and 5); Tokat (4). 4 ô, 4 ㅇ.

Europe, N. Africa, Siberia to Japan, Transcaucasia, N. Iran and Himalayas.

\section{Cladius ordubadensis Konow}

Greece: Samothrace, Therme, 3 ô, I ㅇ, I6.viii.I962 (Guichard \& Harvey).

Crimea, Cyprus, Lebanon and Transcaucasia.

Priophorus morio Lepeletier

Europe, Transcaucasia, Iran, Siberia, to Japan and N. America.

\section{Priophorus pallipes Lepeletier}

Europe, Transcaucasia, Siberia to Japan and N. America.

\section{Priophorus rufipes Lepeletier}

Priophorus ulmi (L.) Konow, nec L.

Europe, Turkey, Transcaucasia.

Trichiocampus viminalis (Fallén)

Europe, Transcaucasia, Siberia to Japan and N. America.

PSEUDODINEURINI

\section{Pseudodineura fuscula (Klug)}

Europe, Transcaucasia and Siberia. 


\section{HOPLOCAMPINI \\ HOPLOCAMPA Hartig}

The species of this genus segregate naturally into 3 distinct groups, all feeding as larvae in the fruits of Rosaceae: two groups attached to the Prunoidea and one to the Pomoidea. Unfortunately the major group characters, the shape of the clypeus, the direction of the inner eye-margins and the pubescent clothing of the underthorax, have not been mentioned in previous descriptions, and it is not therefore always possible to place species I have not examined.

\section{Key to SPECIES-GRoups}

I

Clypeus broadly and shallowly emarginate in front to a depth less than half total length of clypeus, or (i.e. flava) mesepisternum densely pubescent all over and eyes large so that they are closer together in front than $I \frac{1}{4}$ times their own greatest length. Attached to Prunus (Prunoidea) . . .

Clypeus deeply excised in front to a depth of at least half the total clypeal length. Lower mesepisternum and mesosternum at least partly glabrous (with areas devoid of hair follicles). Eyes always further apart in front than $\mathrm{I} \frac{1}{4}$ times their length. Attached to Pomoidea: Eurasian species : alpina Zetterstedt (Sorbus); aviae Benson (Sorbus); brevis Klug (Pyrus); crataegi Klug (Crataegus) ; ephippiata Konow (Malus), pectoralis Thomson (Crataegus); plagiata Klug (Amelanchier); pyricola Rohwer (Pyrus); ? sino-birmana Malais; testudinea Klug (Malus) (Text-fig. 39).

Nearctic species (apart from introductions): alpestris Rohwer (Amelanchier); bioculata Rohwer (Amelanchier); halcyon Norton (Amelanchier); montanicola Rohwer (Amelanchier); oskina Ross (Crataegus); pallipes Macgillivray (Amelanchier); ritcheri Ross (Crataegus); and texas Ross (Crataegus)

testudinea-group

2 (I) Eyes strongly diverging in front (where they are further apart than $\mathrm{I} \frac{1}{2}$ times their length). Mesepisternum below and mesosternum mainly glabrous. Nearctic species: idaho Ross; lacteipennis Rohwer (Text-fig. 38); marlatti Rohwer; nalema Ross; ? Ashmead . . . . . . oregonensis-group

Eyes subparallel in front (where they are closer together than $\mathrm{I} \frac{1}{2}$ times their length). Mesepisternum and mesosternum densely pubescent.

Eurasian species: chrysorrhoea Klug; flava L.; ? formosana Malaise; minuta Klug; prunicola sp. n.; rutilicornis Klug (Text-fig. 37).

Nearctic species: cookei Clarke; oskima Ross .

Hoplocampa testudinea (Klug)

Europe, Turkey and Transcaucasia.

\section{Hoplocampa brevis (Klug)}

Europe and Transcaucasia.

\section{*Hoplocampa crataegi (Klug)}

Turkey, W.: Bursa (I and 3). 8 ô, 9 우 from Crataegus blossom.

A very dark form in which in the $o$ the antenna, postocellar region and occiput 

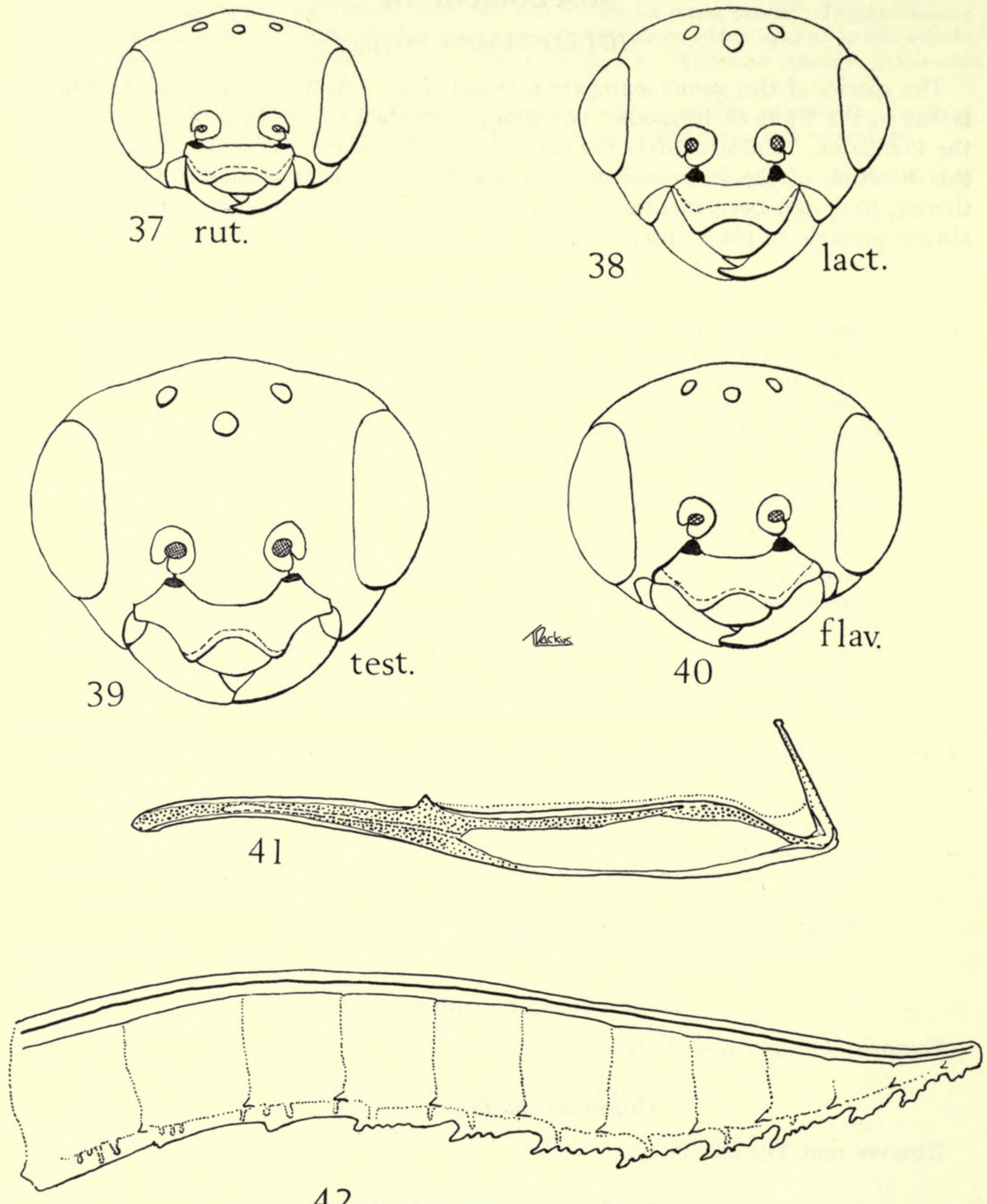

42

Figs. 37-42. 37-40. Hoplocampa faces: 37, rutilicornis; 38, lacteipennis; 39, testudinea; and 4 o, flava. $\quad 4{ }^{\mathrm{I}-42} . \quad$ Hoplocampa prunicola sp. n.: 4I, penis-valve; and 42 , saw. 
of head, almost the entire mesonotum and the hind tibia are black and the stigma of the fore wing is slightly infuscate basally.

C. and S. Europe and Turkey.

\section{Hoplocampa pectoralis Thomson}

N. Iran: Mazandaran, Pankaj Rostaq, I +, 29.iv.I967 (D. B. Baker).

Europe, Transcaucasia and N. Iran.

\section{Hoplocampa flava (L.)}

Turkey, S.: Antalya (II). I ổ at flowers of Prunus insititia L.

Europe, Israel, Turkey and Transcaucasia.

\section{*Hoplocampa prunicola sp. n.}

(Text-figs. 4I, 42)

ㅇ. Reddish yellow with the following parts black or piceous: ocellar region, front edge and hind margin of pronotum, middle line of front mesonotal lobe, most of lateral mesonotal lobes, middle line and hind edge of scutellum and its post-tergite, mesepimeron and metepimeron above, sclerotised parts of Ist-3rd tergites, and following tergites above. Wings hyaline; stigma and venation very pale brown. Length $4 \mathrm{~mm}$.

Head with clypeus evenly emarginate in front to depth of about one-third of its total length. Eyes subparallel in front and closer than $I_{2} \frac{1}{2}$ times their own greatest measure apart in front $(\mathrm{I} \cdot 4: \mathrm{I} \cdot \mathrm{O})$. Hind ocelli further apart than from hind margin of head as $\mathrm{I} \cdot 0: 0 \cdot 6$, and from eye margin as $\mathrm{I} \cdot 0: 0 \cdot 8$ (= POL : OOL).

Thorax normal but with medial suture of front mesonotal lobes obsolescent.

Abdomen with hypopygium but slightly emarginate each side and ovipositor scarcely as long as hind-femur, without 2nd trochanter, and much shorter than hind tibia. Saw as in Text-fig. 42. Pubescence pale and evenly spread over head and thorax, much shorter than diameter of front ocellus.

Punctation: surface of head and thorax shining between shallow follicles; abdomen shining with faint alutaceous surface sculpture.

$\widehat{o}$ as $q$ but with black more extensive to cover \pm postocellar region and edges of frontal area and occiput of head, the whole of the thorax except the pronotum and tegula, and the whole of the abdomen except the hypopygium; penis-valve as in Text-fig. 4I.

Holotype ㅇ. Turkey: Izmit, Karamursel, I + , 23.iii.rg6I on Prunus $(H$. Birkadesler). B.M. (N.H.).

Paratypes. Same data, 3 ô, 2 ㅇ. B.M. (N.H.).

This species is very closely related to $H$. chrysorrhoea Klug, from which it is distinguished by the almost entirely yellow head in the female and beaked penisvalve in the male (c.f. Text-fig. 4I with Benson, I958, fig. 398 etc.); in the form of its penis-valve it would appear more to resemble $H$. minuta Klug.

The type of the Siberian species, H. ephippiata Konow (ठิ), was borrowed for comparison but this species was found to be scarcely separable structurally, including the penis-valve, from $H$. pectorialis Thomson. 


\section{DINEURINI \\ Caulocampus necopinus Zhelochovtsev}

Transcaucasia.

\section{NEMATINI \\ *Stauronematus compressicornis (Fabricius)}

Turkey, C., N.E. and E.: Corum (2); Amasya (I3); Rize (I); Trabzon (6 and 9); Gumusane (2). 4 ô, 3 오.

Holarctic species.

\section{Pristiphora abbreviata (Hartig)}

Cyprus: Pera Pedi, 700 m., I ㅇ, 4.iv.r952 (G. A. Mavromoustakis).

C. and S. Europe and Transcaucasia, introduced into N. America.

\section{Pristiphora subbifida (C. G. Thomson)}

Turkey, N.: Samsun, I ㅇ, 20.vii.I959 (Guichard).

EUROPE and TURKEY.

\section{Pristiphora conjugata (Dahlbom)}

Turkey, C.: Kula, 2 ㅇ, vi. I952 (Plant. Protection Institute), “ Larva on poplar”. Europe, Asia Minor, Siberia to Japan.

\section{Pristiphora fulvipes (Fallén)}

Turkey, N. and N.E.: Samsun (8); Trabzon (4). 2 ㅇ.

Europe, Asia Minor, Transcaucasia and Siberia.

\section{Pristiphora sp. near fulvipes}

TURKey: Trabzon (I2).

\section{Pristiphora crassicornis (Hartig)}

TURKey: Zonguldak (I); Artvin (3). 2 ô.

EURope and TURKEY.

*Pristiphora rufipes Lepeletier

Turkey: Tokat (I). I i.

Holarctic. 


\section{*Pristiphora ambigua (Fallén)}

Turkey: Giresun (7). $2 \hat{\delta}, 20$ ㅇ.

N. and C. Europe and Asia Minor.

*Amauronematus sternalis Enslin

Turkey, C.: Ankara (I3) (Beynam Forest, I,000 m.). 2 ㅇ․

Europe, Turkey and Siberia.

* Nematinus luteus (Panzer)

Turkey, C. and N.E.: Tokat (3); Rize (3). I §^, 2 우.

EUROPE and TURKEY.

\section{Euura mucronata (Hartig)}

Europe, Transcaucasia, Siberia, Himalayas and N. America.

$$
\text { *Phyllocolpa puella (C. G. Thomson) }
$$

Turkey, N.E.: Giresun (2). I 9 .

Europe and Turkey.

Phyllocolpa leucosticta (Hartig)

Turkey, E.: Gumusane (Soganli Gecidi at I,800 m.). 2 ऽ, 3 ㅇ.

Europe, Turkey, Transcaucasia and Siberia.

Pontania vesicator (Bremi-Wolf)

Europe and Transcaucasia.

Pontania bridgmanii (Cameron)

EUROPE and Transcaucasia.

Pontania viminalis (L.)

EUROPE and TURKEy.

Pontania dolichura (C. G. Thomson)

Subarctic-Subalpine Europe, Transcaucasia, Siberia, N. America.

\section{Croesus septentrionalis (L.)}

TuRkey, N.E.: Trabzon (I4). I 9 .

Europe and Turkey. 
*Croesus varus (Villaret)

Turkey, N.E.: Rize (I). 2 ㅇ.

Holarctic.

*Nematus lucidus (Panzer)

Turkey, N.E.: Artvin (3). I $\$$.

Europe, Cyprus and Turkey.

\section{Nematus salicis (L.)}

Europe and Transcaucasia.

Nematus ribesii Scopoli

Europe and Transcaucasia, introduced into N. America.

Nematus myosotidis (Fallén)

Turkey, C., N., N.E. and E.: Amasya (I3); Samsun (6 and II); Giresun (7); Trabzon (7, 9, I5 and I6); Gumusane (3). 7 б, 9 ㅇ.

Europe, Asia Minor, W. Siberia.

* Nematus oligospilus (Förster)

Turkey, C. and N.E.: Ankara (32); Trabzon (9); Rize (I). I ô, 2 ㅇ.

Holarctic to Himalayas.

* Nematus viridis (Stephens)

Turkey (N.E.): Trabzon (I4 and I5); Rize (5). I ô, 2 ㅇ.

Europe and Asia Minor.

\section{Pachynematus rumicis (L.)}

Europe, Ireland, Transcaucasia, Siberia and Alaska.

*Pachynematus obductus (Hartig)

Turkey, N.E.: Trabzon (I8). I i .

Holarctic species reaching ICELAND and Greenland.

Pachynematus vagus (Fabricius)

Turkey, C. and N.E.: Tokat (I); Trabzon (4). 2 ㅇ.

Holarctic species. 


\section{*Pachynematus? clitellatus (Lepeletier)}

Turkey (E.): Erzurum, Cakmak mountains, 2,200 m., I +, 24.v.Ig6o (E. S. Brown).

\section{Europe and Asia Minor.}

\section{REFERENCES}

Benson, R. B. I930. Nine Sawflies requiring new names. Entomologist 63 : 107.

— 1936. A new species of Mocsarya Konow from Syria (Hymenoptera Symphyta). Proc. R. ent. Soc. Lond. (B) $5: 2-3$.

- I938. European Sawflies of the genus Xyela Dalman (sens. lat.) (Hymenoptera Symphyta). Proc. R. ent. Soc. Lond. (B) $7: 32-36$, figs. I-5.

- I943. Studies in Siricidae. . . Bull. ent. Res. 34 : 27-5I, I7 figs., 3 tables.

1946. Classification of the Cephidae. Trans. R. ent. Soc. Lond. 96:89-108, 39 figs.

195I-58. Hymenoptera Symphyta. Handbk. Ident. Br. Insects 6 (2a-c) : I-252, 8I 5 figs.

- I954. Some Sawflies of the European Alps and the Mediterranean Region (Hymenoptera : Symphyta). Bull. Br. Mus. nat. Hist. (Ent.) 3 (7) : 267-296, 3I figs.

I955. Sawflies (Hymen. Symphyta) of Israel. Bull. Res. Coun. Isvael B, 4:45I-456.

1956. Studies in Dolerini (Hymenoptera: Symphyta). Proc. R. ent. Soc. Lond. (B) 25: $55-63$, I6 figs.

I958a. Sawflies (Hymenoptera Symphyta) of the Apennine Mountains of Italy. Memorie Mus. civ. Stor. nat. Verona $6: 32 \mathrm{I}-325$.

1959. Revision of the European Sawflies of the Tenthredo arcuata-complex (Hymenoptera Tenthredinidae). Proc. R. ent. Soc. Lond. (B) $28: 93-102$, figs. I-I I.

I962. A revision of the Athaliini (Hymenoptera: Tenthredinidae). Bull. Br. Mus. nat. Hist. (Ent.) 11 (7) : 333-382, 58 text-figs.

1965. The Classification of Rhogogaster Konow (Hymenoptera : Tenthredinidae). Proc. R. ent. Soc. Lond. (B) 34 : I05-II2, figs. I-2I.

I966. A new genus of the Lycaotini (Blennocampinae) in Turkey (Hymenoptera Tenthredinidae). Proc. R. ent. Soc. Lond. (B) $35: 75^{-77,} 6$ figs.

Bytinski-Salz, H. I956. Coleoptera and Hymenoptera from a journey through Asia Minor. I. Istanb. Univ. Fen. Fak. Mecm. (B) 21 (4) : 21 I-229 (22I).

Condé, O. I934. Versuch einer Revision einiger mitteleuropäischen Aprosthema-Arten (Hymenoptera, Tent.). Folia zool. hydrobiol. 7 : 20-30.

Dadurian, A. B. 1958. [On the horntail and sawfly fauna of Armenia.] Izv. Akad. Nauk armyan. SSR 11 : 9I-IOI.

Dalla Torre, K. W. von. I894. Catalogus Hymenopterorum 1. Lipsiae.

Dovnar-ZApolskil̆, D. P. I930. Neue oder wenig bekannte Chalastogastra. Russk. ent. Obozr. 24 : 86-94.

I93I. Ein Uebersicht ueber die Blattwespen des Nord-Kaukasischen Gebietes (Hym. Symphyta). Izv. sev.-Kavkaz. Kraev. Sta. Zasch. Rast. 6-7:33-62, io figs., 2 tables.

Enslin, E. I9ı. Das Tenthrediniden-Genus Allantus Jur. Russk. ent. Obozr. $10: 335-372$.

- I9I2-I8. Die Tenthredinoidea Mitteleuropas, I-7. Dt. ent. Z., Beihefte, 1912-1917.

— I920. Die Blattwespengattung Tenthredo L. (Tenthredella Rohwer). Abh. zool.-bot. Ges. Wien 11 : I-96.

— I927. Die Tenthrediniden (Hymenoptera) der Kamtschatka-Expedition, I908-I909. Ezheg. zool. Muz. 37 (1926) : 363-38r.

Ermolenko, V. M. I964. [A Study of the Hymenoptera Symphyta of Ukrainian Woodlands]. Trudy Inst. Zool., Kȳyiv 20 : 98-II9.

Forsius, R. I9I9. Über einige von Bequaert in Nord Afrika gesammelte Tenthredinoidea. Öfvers finska VetenskSoc. Förh. 60 A (13) : I-I I (2).

- I930. Uber die von Mag. phil. Hakan Lindberg in Spanien gesammelten Tenthredinoiden. Commentat. biol. 3 (I5) : I-6. 
Guichard, K. M. \& Harvey, D. H. 1967. Collecting in Turkey 1959, I960 and i962. Bull. Br. Mus. nat. Hist. (Ent.) 19 (4) : 223-250.

Gussakovskiř, V. V. I935-1947. Fauna SSSR. Insectes Hyménoptères. Chalastogastra, 1: I-452, 82 figs. $2:$ I-234, I2I figs.

Kerenskiř, H. N. I926. [Sawflies and Horntails of Rostov-on-Don. Proc. N. Cauc. Peoples University 9]; [not seen] vide Dovnar-Zapolskiř, I93I.

Konow, F. W. 1899. Chalastogastrorum novae species et varietates, quas D. Escalera ex Asia Minor reportavit. Actas Soc. esp. Hist. nat. (2) $8: 203-207$.

- I905. Lydidae, Siricidae and Tenthredinidae. Genera Insect. 27-29.

— I908. Lydidae. Blattwespen aus Tibet. Ezheg. Zool. Muz. 13: 9-25.

Kuznetzov-Ugamskiř, N. N. I929. Tenthredinologische Notizen (Hymenoptera Tenthredinoidea). Zool. Anz. $80: 49-55$.

Malaise, R. I935. New Genera of Tenthredinoidea and their Genotypes (Hymen.). Ent. Tidsk. 56 : $160-\mathrm{I} 78$.

— 1945. Tenthredinoidea of South-East Asia, with a general zoogeographical review. Subfamily Tenthredininae. Opusc ent. Supplementum 4 : I-288, plates I-XX, figs. I-57.

I964. New Genera and Species of the Subfamily Blennocampinae (Hym. Tenthred.). Ent. Tidsk. 85 : 20-39, figs. I-3.

Matsumura, F. igir. Erster Beitrag zur Insekten-Fauna Sachalin. J. Coll. Agric. Hokkaido imp. Univ. 4 : I-I 45, 2 plates.

Maxwell, D. E. I955. Comparative Internal Larval Anatomy of Sawflies (Hymenoptera Symphyta). Can. ent., Supplement $1:$ I-I32, figs. I-I53.

Muche, W. H. I962. Die Tenthredinidae (Hym.), meiner Anatolienausbeute ii. Reichenbachia 1 : 17-20.

- I964. Beitrag zur Kenntnis der Blattwespen Bulgariens mit Beschreibung einer neuen Amasis-Art. Ent. Z. Frankf. a.M. $74: 17-24$.

- I964a. Dolerus asper megapteroides nov. ssp. (Hymenoptera Symphyta). Reichenbachia $4: 3 \mathrm{I}-33$.

PIC, M. I9I6. Hyménoptères nouveaux d'Orient et du nord de l'Afrique. Échange $32: 23-24$.

- I9I7. Notes Hyménoptèrologiques. Échange 33 hors texte : I-4.

— I918. Description diverses de Tenthredinides et notes. Échange 34, hors texte : I-4.

- 1925. Hyménoptères nouveaux. Échange 41 : I2-I5.

Ross, H. H. i95i. In Muesebeck, C. F. W., Krombein, K. V. \& Townes, H. K. Hymenoptera of N. America north of Mexico, Synoptic Catalog. Agriculture Monogr. 2, I420 pp.

Weiffenbach, H. I967. Eine neue Rhogogaster aus Kleinasien. NachrBl. Bayer. Ent. [In press].

Zhelochovtsev, A. I928. Über paläarktische Dolerinae. Zool. Anz. 79: Io5-II2.

- I94I. On the Sawflies of Armenia. Sb. Trud. gos. zool. Muz. 7 : 123-153.

Zirngiebl, L. I956. Blattwespen aus Iran. Mitt. münch. ent. Ges. $46: 322-326$.

\section{INDEX TO NEW SPECIFIC NAMES AND TO NEW SYNONYMY}

Synonyms in italics

adequata, Tenthredo, I8I (footnote)

afra, Tenthredo, I8I (footnote)

africanus, Dolerus, $\mathrm{I} 37$

albata, Tenthredopsis, ${ }_{5} 8$ (footnote)

amurensis, Calameuta, I22

andrei, Allantus, I8I (footnote)

andrei, Tenthredopsis, ${ }_{5} 8$ (footnote)

antigae, Allantus, I8I (footnote)

apicicornis, Monoplopus, 122

armenius, Ateuchopus, I23 balcana, Tenthredo, I59 (footnote)

balteatus, Allantus, I8I (footnote)

bensoni, Urocerus augur, I 6

benthini, Tenthredo, 159 (footnote)

bleusei, Schizoceros, 128

bleyli, Amasis, I32

brevis, Pachycephus, II 8

brunnescens, Thomsonia, I6o (footnote)

byzantina sp. n., Sciapteryx, 188 
camtschatkali, Tenthredopsis, I57 (footnote) casia, Tenthredopsis, I59 (footnote) clementi, Kokujewia, I 28 cognata, Macrophya, I8I (footnote) contiguus, Allantus, I82 (footnote) continentalis, Thomsonia, I6o (footnote) corcyrensis, Tenthredopsis, ${ }_{5} 8$ (footnote) CORNARIA, $\mathrm{I}_{52}$ coronatus, Thrinax, I34 corynetes, Macrophya, I8I (footnote)

deannulata, Thomsonia, I6o (footnote) debilis, Arge, I 26

decoratus sp. n., Characopygus, I I9 diana ssp. n., Tenthredo maculata, I 74 diaphenia sp. n., Macrophya, I95 diversipes, Allantus, I8I (footnote) dulcis sp. n., Elinora, I 84 dusmeti, Allantus, I 83 (footnote)

excisa, Perineura, I 58 (footnote) euphorbiae sp. n., Tenthredo, I77

festiva, Calameuta, I 22 fuscicornis, Thomsonia, I6o (footnote) fuscitarsis, Selandria, I35

gastrica, Hylotoma, I 28 geniculatus Lepeletier, Dolerus, I37 gribodoi, Allantus, I8r (footnote) grombczevskii, Cephus, I22 guichardi, Elinora, I8I (footnote) guichardi sp. n., Tenthredopsis, I62

haematica sp. n., Corynis, I 30 hamata sp. n., Macrophya, I94 harveyi sp. n., Tenthredopsis, I63 helveticus, Allantus, I7I henschi, Schizoceros, I 28 hungarica, Tenthredo, I 58 (footnote) hyrcanus sp. n., Dolerus, I4I hyrcana sp. n., Scolioneura, I49 hyrcana sp. n., Tenthredo, I 72

infernalis, Cephus, I22

jugalis, Allantus, I7I jugurtha, Macrophya, I8I (footnote)

kaveli, Allantus, $\mathrm{I} 85$ kussariensis, Allantus, I77

lacteore ssp. n., Aglaostigma aucupariae, I 55 lactiflua, Tenthredo, I 58 (footnote) laevinota ssp. n., Kaliofenusa ulmi, I 50 limbergorum, Tenthredo, I8I (footnote) luminosus, Allantus, I7I

megapteroides 우, Dolerus, I4 I merceti, Allantus, I 7I meridionalis, Euromostethus, I5 I minerva sp. n., Macrophya, I97 montivagus sp. n., Dolerus, I38

nazareensis, Allantus, I 72 nigriceps, Dolerus, I37 nigripes, Schizoceros, 128 nigritarsis, Hylotoma, I 26 nigrorufa, Thomsonia, I59 (footnote) nitens ssp. n., Eriocampa ovata, I 54 notatus, Cephus, I20

oedipus sp. n., Macrophya, I94

quadrannulata, Tenthredopsis, I59 (footnote)

palestina, Kokujewia, I 28

pectoralis, Allantus, I8I (footnote) pisinna, Tenthredopsis, I59 (footnote) proxima, Hylotoma, I 26 prunicola sp. n., Hoplocampa, 201 punctatus, Tristactus, II 5

ruficornis, Thomsonia, I6o (footnote)

sachalinensis, Tenthredo, I57 (footnote) sahariensis, Tenthredo, I8I (footnote) sanctus, Spatulocephalus, I I 8 sarta, Amasis, I32 seljuki ssp. n., Arge clavicornis, I 27 seljuki ssp. n., Dolerus anticus, I 37 serena, Allantus, I 72 stolida sp. n., Elinora, I 85 striatipes, Allantus, I8I (footnote) syriaca, Hylotoma, I 25

tanaiticus, Cephus, I2O tenuicornis, Astatus, 124 tischbeini, Tenthredo, I59 (footnote) tricolor, Allantus, I82 (footnote) triforis, Tenthredopsis, I59 (footnote) tunetensis, Allantus, I8I (footnote) turanica, Arge, I26 turanicus, Cephus, I22 vernalis, Sciapteryx, I87 (footnote) xanthorius, Allantus, I79 (footnote) zarudnyi, Arge, I 26 


\section{$2 \mathrm{BHL}$ Biodiversity Heritage Library}

Benson, Robert B. 1968. "Hymenoptera from Turkey (Symphyta)." Bulletin of the British Museum (Natural History) Entomology 22, 109-207. https://doi.org/10.5962/bhl.part.9952.

View This Item Online: https://www.biodiversitylibrary.org/item/19410

DOI: https://doi.org/10.5962/bhl.part.9952

Permalink: https://www.biodiversitylibrary.org/partpdf/9952

\section{Holding Institution}

Natural History Museum Library, London

\section{Sponsored by}

Natural History Museum Library, London

\section{Copyright \& Reuse}

Copyright Status: In copyright. Digitized with the permission of the rights holder.

Rights Holder: The Trustees of the Natural History Museum, London

License: http://creativecommons.org/licenses/by-nc-sa/4.0/

Rights: http://biodiversitylibrary.org/permissions

This document was created from content at the Biodiversity Heritage Library, the world's largest open access digital library for biodiversity literature and archives. Visit BHL at https://www.biodiversitylibrary.org. 